\title{
WYPISY ŹRÓDŁOWE DO BIOGRAFII POLSKICH BISKUPÓW I OPATÓW Z CZASÓW RZECZYPOSPOLITEJ OBOJGA NARODÓW ORAZ NIEWOLI NARODOWEJ DOBY ZABORÓW (XVI-XIX W.)*
}

\author{
(CZ. XII)
}

„W wieku XIX, wraz z generalną likwidacją klasztorów przez zaborców, [miały miejsce] ogromne straty w zasobach książek i archiwów klasztornych, niszczonych, przewożonych w rozmaitych kierunkach, rozdrapywanych. Utrudniało to i utrudnia niezmiennie do dzisiaj badania nad zakonami [na ziemiach polskich]. Inaczej jest np. $\mathrm{z}$ diecezjami, które nie uległy - generalnie biorąc - likwidacji i zachowywały o wiele lepiej swoje zasoby [aktowe]. Jest rzeczą niezmiernie ważną, by w badaniach nad [staropolskimi] wspólnotami zakonnymi pamiętać o tych wyjątkowych stratach i ogromnych lukach w dokumentacji, jaką dziś posiadamy, i to dotyczących spraw o zasadniczym znaczeniu dla kolejnych pokoleń zakonnych" - pisał w świeżej daty syntezie Wspólnoty zakonne w średniowiecznej Polsce Jerzy Kłoczowski ${ }^{1}$ Pośród owych „spraw o zasadniczym znaczeniu” poczesne miejsce zajmowała troska o pamięć odnośnie do stojących na czele poszczególnych wspólnot monastycznych przełożonych, znajdująca wyraz w spisywanych - nieraz ze znaczną skrupulatnością - wykazach czy nawet rozbudowanych katalogach opatów (prepozytów). Podobnie jak średniowieczne katalogi biskupów, stanowiły one dla kolejnych generacji doniosłej wagi «punkt odniesienia» w konstruowaniu obrazu dziejów i budowaniu świadomości historycznej danej społeczności, zaś dla późniejszych badaczy cenne źródło nie tylko chronologicznej natury.

* Artykuł został przesłany do tomu 99 (2013) „Archiwów Bibliotek i Muzeów Kościelnych”, stąd też w Wykazie postaci uwzględnionych w częściach I-XII (s. 193-214) podawany jest ten tom [przyp. red.].

${ }^{1}$ J. Kłoczowski, Wspólnoty zakonne w średniowiecznej Polsce (Dzieje chrześcijaństwa Polski i Rzeczypospolitej Obojga Narodów, ser. I, t. 3), Lublin 2010, s. 13 (zob. tamże uwagę w przyp. 8). 
Na skutek wspomnianych w cytacie nieszczęść losowych wiele tego rodzaju zabytków uległo zatraceniu i dziś okazuje się stanowić znaczną trudność samo odtworzenie wykazów przełożonych dawnych opactw i prepozytur z ziem polskolitewsko-ruskich (zwłaszcza w przypadku tych konwentów, które uległy kasatom), a tym bardziej precyzyjne określenie chronologii następstwa. W owych okolicznościach tym większą wartość mają dla historyków innego rodzaju dokumenty - zwłaszcza urzędowego charakteru, dzięki którym możliwe jest ustalenie, kiedy dany opat (prepozyt) rządy rozpoczął i kiedy dobiegły one końca. W poprzednich częściach Wypisów źródłowych wiele tego rodzaju świadectw zostało już wydanych drukiem, zaś kolejną ich porcję korzystający znajdzie poniżej. Tym razem zdecydowaną większość spośród nich zaczerpnięto z archiwów rzymskich, które niezmiennie pozostają w znikomym stopniu przeszukane pod katem obecności w nich poloniców z czasów nowożytnych i niewiele wskazuje, aby prędko miał ów stan rzeczy ulec zmianie na korzyść. W tej sytuacji każda, choćby cząstkowa edycja, może okazać się ważnym bodźcem dla dalszych poszukiwań na tym kierunku, zaś zawarte w niej świadectwa, nawet gdy są to typowe varia, uzupełnić dostępny zasób faktografii o brakujące uprzednio «ogniwa» - nieraz pierwszorzędnej wagi.

Obecny, ostatni już (o czym dalej) odcinek cyklu Wypisów źródtowych, podzielony został na trzy części. Pierwsza, to właśnie Monastica, z dokumentami prezent (nominacji), elekcji, konfirmacji (potwierdzeń), ewentualnie rezygnacji opatów (prepozytów generalnych) oraz ksień, jak też z zapiskami na temat ich zgonów, pozwalającymi w sposób precyzyjny wyznaczyć ramy czasowe sprawowania przełożeństwa przez konkretną osobę. W części drugiej, zatytułowanej Varia, korzystający znajdzie świadectwa odnoszące się do członków staropolskiego episkopatu polsko-litewsko-ruskiego - tym razem bez uszeregowania według «kategorii» wydarzeń, do jakich się odnoszą (przypomnijmy, że w poprzednich częściach były to: narodziny/chrzest, święcenia, konsekracje, zgony oraz inne). Wydawca jest świadom, że owo łączne ujęcie różnorodnego rodzaju przekazów, warunkowane sygnalizowanym faktem, że chodzi o ostatnią część cyklu, z punktu widzenia osoby korzystającej nie stanowi czegoś wychodzącego naprzeciw oczekiwaniom, a wręcz przeciwnie. Wynikająca z powyższego niedogodność przestaje mieć wszakże znaczenie w sytuacji, gdy do całości został sporządzony indeks (wykaz), stanowiący ową trzecią część przedkładanej uwadze zainteresowanych publikacji i obejmujący całość serii. Postulowany przez kolejnych recenzentów (każda bowiem z części Wypisów źródlowych była recenzowana przez innego specjalistę, spośród których wszyscy wykazali w owym punkcie pełną zgodność, podzielaną również przez piszącego te słowa), pozwala on na łatwe stwierdzenie, czy zainteresowany konkretną postacią kwerendzista znajdzie w Wypisach źródłowych informacje na jej temat, a jeśli tak, to w którym z tomów półrocznika „Archiwa, Biblioteki i Muzea Kościelne” (ogólne uwagi odnośnie do konstrukcji indeksu zawarte zostały na samym jego początku).

Zakończenie - wraz z niniejszą częścią - rozpoczętego przed dekadą cyklu nie wynika w żadnym wypadku z wyczerpania zasobu przystających do koncepcji serii świadectw, które można (i zarazem byłoby warto) wydać drukiem - przeciw- 
nie, ich liczba pozostaje wprost nieoszacowana. Nie oznacza to również braku orientacji po stronie piszącego te słowa, gdzie jeszcze należy poszukiwać stosownych wiadomości i w konsekwencji niedostatku materiału, który by można w ramach owego cyklu zaprezentować. W zasadniczej mierze na decyzji o zakończeniu kontynuowanej począwszy od roku 2004 serii zaważyły względy pozamerytoryczne, związane $\mathrm{z}$ brakiem warunków dla dalszego prowadzenia poszukiwań archiwalnych i opracowywania ich rezultatów, z czym wszak wiążą się wymagania natury nie tylko warsztatowej. Pozostaje wyrazić nadzieję, że opublikowany dotychczas materiał ułatwi badaczom kompletniejsze ukazanie podejmowanych tematów (nie tylko z historii Kościoła), do których odnoszą się te świadectwa, jak też stanowić będzie wskazówkę, gdzie można znaleźć związane z daną problematyką przekazy, dotąd często niezauważone, których rozproszenie, idące w parze ze słabym rozpoznaniem zachowanej po minionych generacjach spuścizny piśmienniczej, stanowi jedną z fundamentalnych trudności w procesie opisu minionych wydarzeń.

$$
* * *
$$

\section{SKRÓTY ARCHIWALNE}

-AGAD - Archiwum Główne Akt Dawnych w Warszawie:

Archiwum Warszawskie Radziwiłłów, Dział VI, sygn. II-80a; Dział VIII, sygn. 353 [Księga metryczna klasztoru benedyktynek w Nieświeżu], sygn. 354 Книга несвіежского бенедиктинскаго девичего $\mathrm{III}^{\Sigma}$ классного монастыра [...] составленна 31 января 1844 года

-APBKr - Archiwum Prowincji OO. Bernardynów w Krakowie:

S-Wi-4, S-Wi-5

-ASPF - Archivio Storico De Propaganda Fide, Rzym:

Scritture riferite nei Congressi: Moscovia, Polonia e Ruteni, vol. 2, 3, 13, 15, $17,18,19$

-ASR - Archivio Storico di Roma, Rzym: 14

Paesi Stranieri (sec. XVII-XVIII), Busta 11, fasc. [1], fasc. 3; Busta 12, fasc.

-ASV - Archivio Segreto Vaticano, Rzym:

Archivi delle Rappresentanze Pontificie, Varsavia, vol. 117; Archivio Concistoriale, Congregationis Consistorialis Acta, 1796-1799, 1814-1817; Archivio Concistoriale, Processus Datariae, vol. 118, 140, 142; Archivio Concistoriale, Processus Consistorialis, vol. 101, 182, 187, 188; Miscellanea, Armadia I, vol. 84; Segretaria di Statto, Polonia, Add. 4, Add. 21A, Add. 22

BKSC - Biblioteka Księży Salezjanów w Czerwińsku:

b. sygn. Liber mortuorum pro inscribendis, post consummatam vitam, charissimorum confratrum aeque ac piissimorum huius canonicae nostrae Cervenensis fundatorum et benefactorum, nominibus propter aeviternam quotannis in die obitus forum recolendam memoriam, tum propter subsidium charitativum, animabus quoque eorum, in perpetuum exhibendum, anno Domini millesimo septingentesimo septuagesimo octavo comparatus 
-BN - Biblioteka Narodowa w Warszawie:

BOZ 941

-CVIA - Centrinis Valstibinis Istorijos Archyvas, Wilno:

F 1135 ap. 20

-LMAB - Lietuvos Mokslŭ Akademijos Biblioteka, Wilno:

F $9-162-166$

$* * * * *$

MONASTICA

Białobłocki Kazimierz Jan opat (Bledzew)

prowizja papieska 12 III 1685

intromisja $24 \mathrm{IV} 1686^{2}$

Innocentius episcopus, servus servorum Dei, dilecto filio Casimiro Bialoblocki, abbati monasterii abbatiae nuncupati Beatae Mariae Bledzoviensis, Posnaniensis dioecesis, salutem etc. Cum sicut accepimus, monasterium abbatiae nuncupatum Beatae Mariae Bledzoviensis, Cisterciensis Ordinis, Posnaniensis dioecesis, ad quod dum pro tempore vacat, personae idoneae electio ad pro tempore existentes conventum et monachos dicti monasterii spectat et pertinet, cuique quondam Christophorus Sokolnicki, ipsius monasterii abbas regularis, dum viveret praesidebat, per obitum dicti Christophori, [qui] extra Romanam Curiam de mense Septembri proximi praeteriti debitum naturae persolvit, abbatis regimine destitutum existat, et quod illius provisio ad Sedem Apostolicam legitime devoluta existat, nos [...] sperantes, quod tu, qui, ut asseris, in sacro ordine constitutus, probatus et ipsum Ordinem expresse professus es, ac eiusdem Ordinis in Regno Poloniae secretarius existis, [...] eidem monasterio de abbate canonice provisum, de persona tua apostolica authoritate providemus teque in abbatem praeficimus [...]. Datum Romae, apud S. Mariam Maiorem, anno Domini 1685, tertio Idus Martii, pontificatus nostri anno nono, scilicet anno 1685, duodecima Martii

ASR, Paesi stranieri (sec. XVII-XVIII), Busta 12, fasc. 14, s. 263-264 nr 16 A (Provisio apostolica abbatiae Bledzoviensis, facta anno 1684). Zob. również: tamże, s. 264-265 nr 16 B;

${ }^{2}$ Por.: Wypisy źródlowe do biografii polskich biskupów i opatów z czasów Rzeczypospolitej Obojga Narodów oraz niewoli narodowej doby zaborów (XVI-XIX w.), wyd. K.R. Prokop, cz. 11, „Archiwa, Biblioteki i Muzea Kościelne”, 98 (2012) s. 365 nr 1. Także: Nekrolog klasztoru cystersów w Paradyżu (Archiwum Państwowe w Poznaniu • Cystersi • Paradyż 15), wyd. R. Witkowski w: Monastica Polonorum. Fontes et studia, t. 1, red. A.M. Wyrwa, R. Witkowski, t. 1, Warszawa 2009, s. 108 (tamże przyp. 67); Z. Iwicki, Konwent oliwski (1186-1831). Leksykon biograficzny i nie tylko, Gdańsk-Pelplin 2010, s. 188-189. 
ASV, Miscellanea, Armadia I, vol. 84, k. 372v-373r nr 16 (Provisio apostolica abbatiae Bledzoviensis facta monacho anno 1684).

Bledzoviensis abbatia, Ordinis Cisterciensis, Posnaniensis dioecesis, vacans anno 1684, de mense Septembri, per obitum Christophori Sokolnicki, abbati regularis, petita fuit in commendam a Domine Joanne Gninski, vicecancellario Regni, vigore nominationis regiae et iurispatronatus praetensi ad dictam abbatiam sed fuit ipsi denegata [...]. Unde fuit postea collata a Sede Apostolica [...] Casimiro Bialoblodzki, monacho, sub datum: Romae, anno 1685, quarto Idus Martii. Antequam autem expeditae essent literae apostolicae mortuus est idem vicecancellarius de mense Maii eiusdem anni, post cuius obitum alius Joannes Kurdwanowski, Regni magnus notarius, praesentatus a rege ad eamdem abbatiam, qui cum instetisset sibi concedendi dictam abbatiam in commendam vigore iurispatronatus, $[\ldots]$ obtinuit negativam $[\ldots]$. Et sic fuerunt expeditae literae apostolicae ad favorem dicti Casimiri monachi [...], [qui] immissus fuit in possessionem eiusdem abbatiae 24. Aprilis 1686.

ASR, Paesi stranieri (sec. XVII-XVIII), Busta 12, fasc. 14, s. 191-192. Zob. również: tamże, s. 29 § I („Monasterium Bledzoviense, dioecesis Posnaniensis. De quo fuit provisus in abbatem regularem 1685 in Martio P.D. Casimirus Bialoblocki”).

\section{Bidziński Celestyn opat (Płock)}

prowizja papieska 21 XI 16903

Plocensis abbatia S. Adalberti, Ordinis S. Benedicti, Plocensis civitatis, vacans anno 1688 per assecutionem episcopatus Posnaniensis obtenti ab Illustrissimo Domino Stanislao Wytvicki [Witwicki] (qui dictam abbatiam obtinuerat in commendam cum decreto revertendi in titulum), reducta fuit in titulum a sanctae memoriae Alexandro VIII. et collata [...] Patri Caelestino Bidzinski, monacho eiusdem Ordinis, sub datum: Romae, anno 1690, undecimo Kalendas Decembris, et successive fuit etiam collata in commendam Reverendissimo Stanislao Buglevski, ad regiam praesentationem. [...] Sed Pater Bidzinski timuit suae provisionis bullas expedire ob litem contra dictam commendam, non valens eandem sustinere litem.

ASR, Paesi stranieri (sec. XVII-XVIII), Busta 12, fasc. 14, s. 196.

\section{Borzobohata Wiktoria Katarzyna ksieni (Nieśwież)}

wstapienie do zakonu 25 XI $1787^{4}$

\footnotetext{
${ }^{3} \mathrm{~K}$. Wiśniewski, Instytucja komendy w konwencie płockim benedyktynów w XVI-XVIII wieku, w: Zakony rzymskokatolickie na Mazowszu (z uwzględnieniem Kurpiowszczyzny), oprac. zbior., Ostrołęka 2008, s. 122 (całość - s. 114-128). Por.: A.J. Nowowiejski, Płock-monografia historyczna, Płock $[1931]^{2}$, s. 554.

${ }^{4}$ M. Borkowska, Stownik polskich ksień benedyktyńskich, Niepokalanów 1996, s. 15-16; taż, Leksykon zakonnic polskich epoki przedrozbiorowej, t. 3 - Wielkie Księstwo Litewskie i ziemie ruskie Korony Polskiej, Warszawa 2008, s. 106.
} 
Wiktoryja Katarzyna Borzobohatówna wstąpiła do zakonu mając lat 18 [dnia] 25 miesiąca Novembra 1787 roku.

AGAD, Archiwum Warszawskie Radziwiłłów, Dział VIII, 353, s. 27 nr 289; zob. również: tamże, Dział VIII, 354 (w r. 1834 ksienią (настоительница) klasztoru benedyktynek w Nieświeżu była Katarzyna Borzobohatówna, lat 65, która do zakonu wstąpiła w 1787, a profesję złożyła w 1789; rządy jako ksieni objęła po Teofili Kościuszkównie).

Brzechwa Kazimierz opat (Trzemeszno)

zgon 8 III $1724^{5}$

Die 8va Martii. [Obitus] Reverendissimi [Domini] Casimiri Brzychwa, abbatis Tremesnensis, qui obiit anno 1724.

BKSC, Liber mortuorum [abbatiae] Czervenensis, s. 124.

Chrzanowska Benedykta Florentyna ksieni (Nieśwież)

elekcja 21 VIII 1738

benedykcja 22 VIII $1738^{6}$

Dnia 21 VIII 1738 r., z rana, stanęła [w Nieświeżu] elekcja panny ksieni, na którą godność obrana Jmć Panna Benedikta Chrzanowska, mniszka grzeczna. Dnia 22 VIII 1738 r. asystowałem [słowa odnoszą się Michała Kazimierza Radziwiłła] konsekracyi panny ksieni, którą ceremonię sam biskup [wileński Michał Jan] Zienkowicz robił.

AGAD, Dział VI, II-80a, s. 931.

Denhoff Aleksander komendatoryjny opat-koadiutor (Jędrzejów)

elekcja 5 VIII $1642^{7}$

Anno 1642, die vero 5. mensis Augusti, Reverendi Patres Martinus Suleiovius, prior, Martinus Kardziowski [Karniowski?] totusque conventus fratrum monaste-

${ }^{5}$ Archiwum trzemeszeńskie, oprac. J. Łukowski, Poznań 1881 [osobne odbicie z „Roczników Towarzystwa Przyjaciół Nauk Poznańskiego”, 11 (1881)], s. 68 (,abbatiam in manus Sanctissimi per plenipotentem resignavit anno 1713”), 71 (opat 1699-1713), 73 (nr 6).

${ }^{6}$ Borkowska, Stownik polskich ksień, s. 21; taż, Leksykon zakonnic polskich, t. 3, s. 99 (,ksieni od 1738 r.").

${ }^{7}$ W. Bukowski, Katalog opatów jędrzejowskich. Próba ustalenia chronologii, w: Cystersi w Polsce. W 850-lecie fundacji opactwa jędrzejowskiego, pod red. D. Olszewskiego, Kielce 1990, s. 198 (,został z polecenia królewskiego wybrany 5 VIII 1642 r. na koadiutora opactwa jędrzejowskiego"). Nadto: Liber mortuorum monasterii Andreoviensis Ordinis Cisterciensis, wyd. W. Kętrzyński, w: Monumenta Poloniae Historica, t. 5, Lwów 1888, s. 771, 799. 
rii Andreoviensis Ordinis Cisterciensis, capitulariter congregati, in praesentia Reverendissimi Domini Alexandri Trzebinski, nominati episcopi Premisliensis, tum visi literis commendationis Sacrae Regiae Maiestatis in et super coadiutorem, videlicet Dominum Alexandrum Denhoff, per memoratum Reverendissimum Dominum Alexandrum Trzebinski assumptum, electum et deputatum, omnes unanimi voce consensum praestandum et dandum duxerunt, prout praestiterunt et dederunt, dictumque Dominum Alexandrum Denhoff in coadiutorem, etiam cum futura successione in administratione spiritualium et regimine temporalium, [...] palam et libere elegerunt et deputaverunt.

ASV, Segreteria di Stato. Polonia, Add. 4, b.p. (dokument notarialny, poświadczający wybór Aleksandra Denhoffa na koadiutora przy komendatoryjnym opacie jędrzejowskim Remigiuszu Koniecpolskim); toż w: ASR, Paesi stranieri (sec. XVII-XVIII), Busta 12, fasc. 14, s. $460 \mathrm{nr} 41$ (dokument sporządzony przez notariusza publicznego Jana Grabowskiego; w czasie wyboru Aleksandra Denhoffa reprezentował prokurator Zygmunt Koniecpolski).

\section{Denhoff Jan Kazimierz komendatoryjny opat (Mogiła), kardynat} prowizja papieska 30 VII $1666^{8}$

Clarae Tumbae abbatia, Ordinis Cisterciensis, concessa fuit in commendam ab Alexandro papa VII. [...] Eminentissimo et Reverendissimo Domino Joanni Casimiro cardinali Denhoff, expeditis literis apostolicis super huiusmodi commenda sub datum: 1666, tertio Kalendas Augusti.

ASR, Paesi stranieri (sec. XVII-XVIII), Busta 12, fasc. 14, s. 194. Zob. również: tamże, s. 29 § VIII (,Monasterium Mogilnense seu Clarae Tumbae, dioecesis Cracoviensis. Quod obtinuit in commendam 1666 in Augusto Illustrissimus Dominus Joannes Casimirus Denhoff, ablegatus regius et commendator S. Spiritus in Urbe").

Dlugołęcki Stanisław opat (Czerwińsk)

elekcja 9 VII 1816 konfirmacja 28 XI $1816^{9}$

Ad dignitatem abbatialem Congregationis Cervenensis Perillustris et Reverendissimus Dominus Stanislaus Długołęcki, praepositus ad aedes Sancti Georgii Varsaviensis, adinventus est. [...] Et quoniam multo maior pars votorum in persona Perillustris ac Reverendissimi Domini Stanislai Długołęcki, praepositi Varsaviensis,

${ }^{8}$ Por.: Wypisy źródłowe do biografii polskich biskupów, cz. 11, s. 370 nr 10. Także: K.R. Prokop, Polscy kardynałowie, Kraków 2001, s. 136-137; W. Jakubowski, M. Solarczyk, Organizacja Kościoła rzymsko-katolickiego na ziemiach polskich od X do XXI wieku, Warszawa-Olsztyn 2011, s. 244.

${ }^{9}$ H. Folwarski, Poczet opatów klasztoru kanoników regularnych $w$ Czerwińsku, „Nasza Przeszłość”, 6 (1957) s. 77-79 („,będąc prepozytem kościoła św. Jerzego w Warszawie [...] w 1816 r. przechodzi na opactwo czerwińskie"). 
praecipuo regularis observantiae zelo, animi dexteritate, in administrandis officiis et dignitatibus sibi commissis, fidelitate et honore profulgentem, generis nobilitate de stemma Grzymała, vitae morumque honestate, aliisque dotibus ab annis triginta novem vitae religiosae seu professionis suae inculpabiliter commendati, Divinis humanisque literis sufficienter instructi, confluxisse, adeoque canonicam electionem extitisse patuit. [...] Nona mensis Julii 1816.

ASV, Archivio Concistoriale, Congregationis Consistorialis Acta, 1814-1817, k. 301r-302v (Publicum electionis iuramentum; „Stanislaus Długołecki, praepositus ad aedes Sancti Georgii Varsaviensis primusque praelatus in Congregatione” obrany został opatem czerwińskim ,post pie defunctum Reverendissimum olim Valentinum Zaboklicki, anno currentis die vigesima tertia mensis Aprilis fatis extinctum") ${ }^{10}$.

Per morte di Valentino Zaboldichi [sic!], ultimo abbate del monasterio Cervenense, nella diocesi di Plosco di Polonia, seguita li 23. Aprile dell'anno corrente, essendosi radunati tutti gli elettori [...] nel giorno 9. Luglio dell'anno medesimo [e] con numero 17 voti fu eletto per via di scrutinio in nuovo abbate Cervenense il Reverendo Stanislao Dlugotechi [sic!], preposito di S. Giorgio di Varsavia, ed amministratore della vacante abbadia [...]. Il sacerdote Stanislao Dlugotechi [sic!], come sopra eletto abbate Cervenense, prega la Santitá Vostra per la conferma della sua elezione.

ASV, Archivio Concistoriale, Congregationis Consistorialis Acta, 1814-1817, k. 299r-302r (1816, d. 28. Novembris. Plocensis. Confirmatio electionis abbatis monasterii Cervenensis).

Falęcki Stanistaw opat (Czerwińsk)

zgon 22 V $1594^{11}$

Die 22 $2^{\underline{d a}}$ Maii. [Obitus] Reverendissimi Domini Stanislai Falęcki, huius canonicae Cervenensis abbatis, qui obiit anno $1594^{\text {to }}$.

BKSC, Liber mortuorum [abbatiae] Czervenensis, s. 199.

${ }^{10}$ Zob. niżej przyp. 51.

${ }^{11}$ W.H. Gawarecki, Wiadomość o starożytnym klasztorze Kanoników Regularnych Lateraneńskich w mieście Czerwińsku niegdyś istniejącym, „Pamiętnik Religijno-Moralny”, 10 (1846) z. 3, s. 201202; Folwarski, Poczet opatów klasztoru kanoników regularnych w Czerwińsku, s. 24-26 („śmierć Stanisława Falęckiego nastąpiła w drugiej połowie 1593 r.”). Nadto: W. Graczyk, Opaci kanoników regularnych regularnych z Czerwińska w kapitule kolegiaty św. Michała w Płocku, w: Przemijanie $i$ trwanie. Kanonicy Regularni Laterańscy $w$ dawnej $i$ wspótczesnej Polsce, pod red. K. Łataka i I. Makarczyk, Kraków [2008], s. 136 (całość - s. 129-136). 


\section{Gniński Bernard Ignacy opat (Koronowo)}

prowizja papieska 27 VII $1686^{12}$

Ignatius Gninski, presbyter saecularis, praesentatus a rege ad abbatiam Coronoviensem, Ordinis Cisterciensis, Vladislaviensis dioecesis, [...] postquam assumpsit habitum et expleta probatione novitiatus per annum emisit professionem regularem, assumpto nomine Bernardi, obtinuit eandem abbatiam [...], expeditis literis apostolicis in forma gratiosa, sub datum: anno 1686, sexto Kalendas Augusti.

ASR, Paesi stranieri (sec. XVII-XVIII), Busta 12, fasc. 14, s. 189-191.

Gurowski Aleksander Benedykt opat (Obra)

elekcja $26 \times 1717$
prezbiterat $25 \mathrm{IV} 1718^{13}$

Anno Domini 1717, die Martis 26. mensis Octobris, in monasterio Obrensi, venerabiles fratres professi Obrenses, una cum Reverendissimo Domino Thoma Francisco Czapski, Ordinis Cisterciensis commissario et vicario generali, capitulariter congregati [...], Religiosum Fratrem Alexandrum Benedictum Gurowski, professum Obrensem, diaconum, recte, legitime et canonice elegerunt in abbatem.

ASV, Segreteria di Stato. Polonia, Add. 21A, cz. 2, k. 302r-v (instrument notarialny).

[Nos] Petrus de Czekarzewice Tarło, episcopus Claudiopolitanus, suffraganeus, vicarius in spiritualibus et officialis generalis Posnaniensis, $[\ldots]$ notum facimus, quia nos intra missarum solemnia sacros ordines conferentes anno Domini 1718, 25. Aprilis, Dilectum Nobis in Christo Reverendissimum Dominum Alexandrum Benedictum Gurowski, electum abbatem Obrensem S. Ordinis Cisterciensis, ad sacrum ordinem presbyteratus promovimus et ordinavimus.

ASV, Segreteria di Stato. Polonia, Add. 21 A, cz. 2, k. 302v.

${ }^{12}$ Series abbatum coenobii Byszoviensis seu Coronoviensis Ordinis Cisterciensis, wyd. W. Kętrzyński, w: Monumenta Poloniae Historica, t. 5, s. $817 \mathrm{nr}$ 36. Nadto: Liber mortuorum monasterii Coronoviensis O.Cist., wyd. A. Mańkowski (Towarzystwo Naukowe w Toruniu. Fontes, t. XXV), Torun 1931, s. 13 (tamże przyp. 4); Teki Dworzaczka. Materiały historyczno-genealogiczne do dziejów szlachty wielkopolskiej XV-XX w., Kórnik 1995-1997 (edycja elektroniczna na CD) [dalej cyt.: Teki Dworzaczka]: Metrykalia > Katolickie>Część $4 \bullet \mathrm{nr} 26707$ (Cystersi wągrowieccy); Monasticon Cisterciense Poloniae, t. 2 - Katalog męskich klasztorów na ziemiach polskich $i$ dawnej Rzeczypospolitej, red. A.M. Wyrwa, J. Strzelczyk, K. Kaczmarek, Poznań 1999, s. 46, 55, 59-60.

${ }^{13}$ Monasticon Cisterciense Poloniae, t. 2, s. 381, 385. Nadto: Liber mortuorum monasterii Coronoviensis O.Cist., s. 34 („20. Februarii 1742 Reverendissimus Benedictus Gurowski, abbas Bledzeviensis") oraz przyp. 3; Nekrolog klasztoru cystersów w Paradyżu, s. 102 (tamże przyp. 56: „opat bledzewski w latach 1722-1742”). 
Gurowski Józef Bernard opat (Przemęt)

elekcja 27 VI 1698

Anno Domini 1698, die 27. mensis Junii [...], constituti suis in personis Admodum Reverendi in Christo Patres et Fratres Guillelmus Stamberski, prior, Pater Edmundus, senior et alii professi monasterii Premetensis Ordinis Cisterciensis [...], in abbatem sui monasterii post mortem et obitum Reverendi olim Alexandri Koszanowski, ultimi ac immediati pastoris, antea electi abbatis Premetensis, Perillustrem Dominum Josephum Gurowski, sacri initiarum ordinibus, uti praelatum dignissimum et a Sacra Regia Maiestate Domino Clementissimo apprime reccomendatum, cum ea tamen conditione, ut ex nunc habitum regularem assumat et regulam Sancti Patris [Benedicti], ac Ordinis profiteatur non aliter, nec alias, postulandum esse decreverunt et vota sua in hunc modum insinuaverunt.

ASV, Segreteria di Stato. Polonia, Add. 22, b.p. (instrument notarialny).

\section{Hacki Michat Antoni opat (Oliwa)}

prowizja papieska (koadiutoria) 18 III 167915

Olivensis abbatia, Ordinis Cisterciensis, Vladislaviensis dioecesis, collata fuit a Sede Apostolica [...] per viam coadiutoriae, de consensu tunc viventis Patri Christophori Loknicki, abbatis regularis, et monachorum eiusdem monasterii, cum futura sucessione, Patri Michaeli Antonio Hacki, monacho eiusdem monasterii, sacrae theologiae doctori, expeditis literis apostolicis super huiusmodi coadiutoria, sub datum: Romae, anno 1679, quinto decimo Kalendis Aprilis.

ASR, Paesi stranieri (sec. XVII-XVIII), Busta 12, fasc. 14, s. 193. Zob. również: tamże, s. 28 § IV (,Monasterium Olivense, dioecesis Vladislaviensis. Abbas regularis P.D. Michael Antonius Hacki, provisus in Aprili 1679").

${ }^{14}$ Monasticon Cisterciense Poloniae, t. 2, s. 375-377, 385. Nadto: Liber mortuorum monasterii Coronoviensis O.Cist., s. 17 („7. Januarii 1718 Reverendissimus Bernardus Gurowski, abbas Bledzeviensis") oraz przyp. 1; Teki Dworzaczka: Metrykalia>Katolickie>Czesść 6 • nr 38234 (Bledzew - cystersi).

${ }^{15}$ Iwicki, Konwent oliwski (1186-1831), s. 66-72 (zwł. s. 69-70: „W 1679 r. (16 III) kandydował na opata w Pelplinie, jednak 29 głosami spośród 33 został wybrany Ludwik Łoś. Po śmierci opata Krzysztofa Łoknickiego przejął 14 XII 1683 r. rządy w opactwie oliwskim. Do tego urzędu był przed czterema laty przewidziany, gdy opat Łoknicki - na wniosek króla [Jana] Sobieskiego - mianował go 14 XII 1679 r. swoim koadiutorem. Wybór został potwierdzony przez Rzym, jednak został za sprawą Kazimierza Białobłockiego, późniejszego opata w Bledzewie, zakwestionowany na sejmiku pomorskim. Szlatchta tutejsza podważała nominację ze względu na nieszlacheckie pochodzenie Hackiego, [jednak] dzięki możnym protektorom i przy poparciu króla utrzymał [on] koadiutorstwo, a następnie objął urząd opata oliwskiego"). Nadto: Monasticon Cisterciense Poloniae, t. 2, s. 273, 278; Z. Iwicki, Nekropolia oliwska, Gdańsk 2004, wg indeksu (zwł. s. 74-79). 
Komornicki Michał Hieronim opat (Święty Krzyż)

[zob. niżej zapiskę odnoszącą się do Krystyna Stanisława Mireckiego]

ASR, Paesi stranieri (sec. XVII-XVIII), Busta 12, fasc. 14, s. 195.

Koniecpolski Remigiusz komendatoryjny opat (Jędrzejów), biskup (Chetm/ Krasnystaw)

elekcja 18 IV $1624^{17}$

Anno 1624, die 18. mensis Aprilis, in conventu Andreoviensi Ordinis Cisterciensis [...]. Quod cum abbatia Andreoviensis per obitum Admodum Reverendi Domini Adami Mąkowski vacet, et ne monasterium suo pastore destitutum absque regimine maneat, venerabiles ac religiosi prior, subprior caeterique fratres dicti conventus, ad quos electio novi abbatis spectat, ad electionem processerunt [...]. Habentes perspectam pietatem et probitatem Admodum Reverendi Domini Remigii Koniecpolski, a Sacra Regia Maiestae commendati, [...] eundem in abbatem et praelatum conventus sui nominaverunt et elegerunt, prout nominant et eligunt, postulantque, quatenus iuxta regulares sanctiones professionem emittat, habitum et tonsuram monachalem deferat, ac iuramentum de observandis canonibus regulae et statutis praestet.

ASV, Segreteria di Stato. Polonia, Add. 4, b.p. (dokument notarialny, poświadczający wybór na opactwo jędrzejowskie Remigiusza Koniecpolskiego); toż w: ASR, Paesi stranieri (sec. XVIIXVIII), Busta 12, fasc. 14, s. 458-459 nr 39 (dokument sporządzony przez notariusza publicznego Samuela Kalinę [Calina]).

Kontski Antoni opat (Przemęt)

prowizja papieska 6 IX 1690

benedykcja 1 II 1699

rezygnacja 11 III $1702^{18}$

Alexander episcopus, servus servorum Dei, dilecto filio Antonio Kontski, abbati monasterii abbatiae nuncupati Beatissimae Mariae Virginis Premetensis,

${ }^{16}$ J. Gacki, Benedyktyński klasztor Świętego Krzyża na Łysej Górze, Warszawa 1873, s. 97-98 („obiit 1689”); M. Kanior, Polska Kongregacja Benedyktyńska Świętego Krzyża 1709-1864, Kraków 2000, s. 42, 44, 90. Także: J. Wiśniewski, Dekanat opatowski, Radom 1907 [reprint: Kielce 2000], s. 467.

${ }^{17}$ Bukowski, Katalog opatów jędrzejowskich, s. 197 („konwent dokonał elekcji 13 V 1624 r.). Nadto: Liber mortuorum monasterii Andreoviensis Ordinis Cisterciensis, s. 771, 798.

${ }^{18}$ Por.: Przemęt. Zarys dziejów, red. K. Zimniewicz, Warszawa-Poznań 1991, s. 118 przyp. 118; Nekrolog klasztoru cystersów w Paradyżu, s. 115 (tamże przyp. 84: „Aleksander Koszanowski, opat przemęcki, wybrany w 1690 r., zmarł 4 III 1690 r.”). 
Posnaniensis dioecesis, salutem et apostolicam benedictionem. [...] Cum sicut accepimus monasterium abbatiae nuncupati Beatissimae Mariae Virginis Premetensis, Cisterciensis Ordinis [...], cui quondam Nicolaus Zegocki, dicti monasterii ultimus abbas, dum viveret praesidebat, per obitum dicti Nicolai, qui de mense Decembris proxime praeteriti debitum naturae persolvit, abbatis regimine destitutum existat ad praesens [...], nos [...] sperantes quod tu, qui, ut asseris, in sacro presbyteratus ordine constitutus et ipsum Ordinem expresse professus es [...], eidem monasterio de abbate canonice provisum, de persona tua apostolica auctoritate providemus teque in abbatem praeficimus [...]. Datum Romae, anno Domini 1690, octavo Idus Septembris.

ASR, Paesi stranieri (sec. XVII-XVIII), Busta 12, fasc. 14, s. 315-316 nr 16 B (Literae apostolicae provisionis de monasterio Premetensi in forma gratiosa [...], concessae P. Antonio Kontski anno 1690, octavo Idus Septembris).

Premetensis abbatia, Ordinis Cisterciensis, Posnaniensis dioecesis, vacans per obitum Nicolai Zegocki, abbatis regularis, secutum 29. Decembris 1689, collata fuit a sanctae memoriae Alexandro VIII. [...], nulla saltem legitima electione facta infra terminum trium mensium, a iure praefixum ad eligendum, Patri Antonio Kontski, monacho eiusdem Ordinis [...] (reiecta instantia Domini Alexandri Koszanowski, canonici custodis ecclesiae cathedralis Posnaniensis, praesentati a serenissimo rege [...]). [...] Et fuerunt expeditae literae apostolicae pro parte Domini Antonii in forma gratiosa sub datum: Romae, anno 1690, octavo Idus Septembris.

ASR, Paesi stranieri (sec. XVII-XVIII), Busta 12, fasc. 14, s. 193-194. Zob. również: tamże, s. 313-314 nr 15 („Electio Alexandri Koszanowski in abbatem monasterii Premetensis Ordinis Cisterciensis, uti facta contra constitutiones apostolicas et Ordinis, cassata fuit per patrem generalem eiusdem Ordinis die 22. Augusti 1690").

Anno Domini 1699, die vero prima mensis Februarii, in ecclesia tituli S. Martini Episcopi et Confessoris monialium Ordinis Carmelitarum Discalceatorum Cracoviae sita, coram Perillustri et Reverendissimo Domino Stanislao de Stupow Szembek, episcopo Dionisiensi, suffraganeo et [pozostawiono puste miejsce] Cracoviensi, personaliter constitutus Reverendus Antonius Kontski, abbas provisus apostolicus abbatiae monasterii Premetensis, dioecesis Posnaniensis, Ordinis Cisterciensis, principalis, iuramentum fidelitatis et obedientiae in manibus praenominati Perillustris et Reverendissimi Domini episcopi, circa sui benedictionem, ad maius altare, iuxta formam introclusam a Sancta Sede Apostolica, [praestitit].

ASV, Segreteria di Stato. Polonia, Add. 22, b.p. (instrument notarialny).

Anno Domini 1702, 11. mensis Martii. Coram officio actisque praesentibus consistorii Varsaviensis constitutus personaliter Perillustris et Reverendissimus Dominus Antonius Kontski, de abbatia Premetensi Ordinis Cisterciensis, dioece- 
sis Posnaniensis sita, per Sedem Apostolicam provisus, principalis, recognovit et confessus est, quia ipse cum ex certis rationabilibus causis ad hoc animum suum moventibus intenderet renunciare iuribus suis ad monasterium et abbatiam Premetensem quaesitis et habitis, quorum occassione acerrima, multumque dispensiosalis et differentia orta fuit inter recognoscentem provisum apostolicum et monachos eorumque electum sive postulatum abbatem Premetensem, Perillustrem et Reverendissimum Dominum Josephum Gurowski, cupiens illud monasterium et abbatiam attritam et pacatam reddere iam ex nunc provisioni apostolicae sibi ad abbatiam Premetensem competenti, omnique iuri ex vi literarum eiusdem provisionis sibi serviendum renunciat, de quibus omnibus cedit et abscedit, nihil sibi iuris, praetextus, praetensionis et iurisdictionis ad regendum, gubernandum et administrandum monasterium bonaque abbatialia Premetensia reservando aut excipiendo. Fr. Antonius Kontski, abbas, manu propria.

ASV, Segreteria di Stato. Polonia, Add. 22, b.p.

Kostecki Jan opat (Jędrzejów)

prowizja papieska 28 I $1682^{19}$

Pater Theodorus Madalinski, abbas [Andreoviensis], obiit die 18. Aprilis 1681. Post cuius obitum provisus fuit a Sede Apostolica in abbatem eiusdem monasterii Pater Joannes Kostecki, monachus, cum expressione dictae gratiae motu proprio papae, et expeditae fuerunt literae apostolicae super huiusmodi provisione in forma gratiosa sub datum: [anno] 1682, 5. Kalendas Februarii.

ASR, Paesi stranieri (sec. XVII-XVIII), Busta 12, fasc. 14, s. 184-187. Zob. również: tamże, s. $28 \S$ I („Monasterium Andreoviense. P.D. Joannes Kostecki, abbas regularis, provisus a Sede Apostolica anno 1682, in Februario").

Koźmińska (Koźmieńska) Ludwika ksieni (Otobok)

zgon 12 VI $1767^{20}$

[Advenit] emissarius Venerabilis Helenae Kowalska, priorissae monasterii Olobocensis, cum literis notificantibus mortem piae defunctae Reverendissimae Ludovicae Kozmienska, abbatissae eiusdem monasterii, quae die 12. praesentis hora octava post meridiem, munita sacramentis, desiit vivere.

${ }^{19}$ Bukowski, Katalog opatów jędrzejowskich, s. 202 („wybrany na opata w lutym 1682 r.”). Nadto: Liber mortuorum monasterii Andreoviensis Ordinis Cisterciensis, s. 771, 785; Liber mortuorum monasterii Landensis Ordinis Cisterciensis, wyd. W. Kętrzyński, w: Monumenta Poloniae Historica, t. 5, s. 486.

${ }^{20}$ Teki Dworzaczka: Metrykalia $>$ Katolickie $>$ Część $6 \bullet$ nr 38590 (Obra-cystersi); Borkowska, Leksykon zakonnic polskich, t. 1 - Polska Zachodnia i Pótnocna, Warszawa 2004, s. 59 (,zmarła 21 VIII [sic!] 1767”). 
ASV, Archivi delle Rappresentanze Pontificie, Varsavia, 117, k. 196r-v (pismo biskupa Fabiana Franciszka Pląskowskiego, sufragana chełmińskiego, do nuncjusza apostolskiego w Rzeczypospolitej Obojga Narodów, z daty: Chełmża, 16 VI 1767 r.).

Kraszewski Mateusz opat (Czerwińsk)

zgon 5 IX $1767^{21}$

Die 5 ${ }^{\text {ta }}$ Septembris. [Obitus] Illustrissimi ac Reverendissimi Domini Mathaei Kraszewski, tertii post exdivisionem bonorum abbatis claustralis Cervenensis, qui plurimis ecclesiis canoniae nostrae incorporatis, praecipuae parochiali Błonensi, et conventuali Cervenensi, munificentissima praestitit beneficia. Obiit autem anno Domini $1767 \stackrel{\mathrm{mo}}{\text {. }}$.

BKSC, Liber mortuorum [abbatiae] Czervenensis, s. 303.

Krzesimowski Antoni opat (Koprzywnica)

prowizja papieska $14 \mathrm{~V} 1685$

intromisja $21 \times 1685^{22}$

Innocentius episcopus, servus servorum Dei, dilecto filio Antonio Krzesimowski, abbati monasterii Coprivnicensis, Cracoviensis dioecesis, salutem etc. Cum sicut accepimus monasterium abbatiae nuncupatum Coprivnicensis, dioecesis Cracoviensis, [...] cui quondam Zbigneus Ossolinski, ipsius monasterii abbas regularis, dum viveret praesidebat, per obitum dicti Zbignei, qui extra Romanam Curiam a quatuor mensibus et ultra debitum naturae persolvit, abbatis regimine destitutum extat ad praesens, et per dilectos filios, conventum et monachos eiusdem monasterii, nulla saltem legitima provisione eidem monasterio facienda electio facta fuerit, propterea illius depositio ad Sedem Apostolicam legitime devoluta existat, nos autem [...] sperantes, quod tu, qui, ut asseris, in sacro presbyteratus ordine constitutus et ipsum Ordinem expresse professus es, eiusdemque monasterio priori munus exerces, [...] eidem monasterio de abbate canonice provisum, $[\ldots]$ de persona tua apostolica authoritate providemus, teque illi in abbatem praeficimus [...]. Datum Romae, apud S. Mariam Maiorem, anno Domini 1685, pridie Idus Maii.

ASR, Paesi stranieri (sec. XVII-XVIII), Busta 12, fasc. 14, s. $262 \mathrm{nr} 15$ A (Provisio apostolica P. Antonii Krzesimowski in abbatem Coprivnicensem, [pridie] Idus Maii 1685; zob. również: tamże, s. $263 \mathrm{nr} 15$ B).

${ }^{21}$ Folwarski, Poczet opatów klasztoru kanoników regularnych w Czerwińsku, s. 60-64 (,umarł we wrześniu 1767 r."); Prokop, Wiadomości do biografii biskupów oraz opatów, s. 306 (5 IX 1767). Nadto: Gawarecki, Wiadomość o starożytnym klasztorze, s. 202, 208 (nr 9).

22 J. Wiśniewski, Dekanat sandomierski, Radom 1915 [reprint: Kielce 2000], s. 73 (Katalog opatów w Koprzywnicy). 
Coprivnicensis abbatia, Ordinis Cisterciensis, Cracoviensis dioecesis, vacans anno 1685, de mense Januarii, per obitum Sbignei Ossolinski, abbatis regularis, collata fuit a Sede Apostolica [...] Reverendissimo Patre Antonio Krzesimowski, tunc priori claustrali eiusdem monasterii, ad presens vicario generali monasteriorum eiusdem Ordinis in Polonia, expeditis literis apostolicis sub datum: Romae 1685 , pridie Idus Maii, [...] [qui] fuit immissus in possessionem eiusdem abbatiae 21. Octobris eiusdem anni, non obstantibus impedimentis praestitis [...] ab Illustrissimo Domino Georgio Denhoff, tunc episcopo Camenecensi, nunc episcopo Praemisliensi, praetendente dictam abbatiam in commendam vigore nominationis regiae.

ASR, Paesi stranieri (sec. XVII-XVIII), Busta 12, fasc. 14, s. 192-193. Zob. również: tamże, s. 28-29 § VII („Monasterium Coprivnicense, dioecesis Cracoviensis. Abbas regularis, provisus a Sede Apostolica 1685 in Maio, P.D. Antonius Krzesimowski”).

Leszczyński Andrzej komendatoryjny opat (Czerwińsk)

zgon 24 II $1681^{23}$

Die 24 ${ }^{\text {ta }}$ Februarii. [Obitus] Perillustris et Reverendissimi Domini Andreae Leszczynski, administratoris perpetui abbatiae nostrae [Czervenensis], qui obiit anno $1681^{\mathrm{m}} \stackrel{0}{\mathrm{a}}$.

BKSC, Liber mortuorum [abbatiae] Czervenensis, s. 111.

Madaliński Stefan Teodor opat (Jędrzejów)

$$
\begin{array}{r}
\text { elekcja } 9 \text { III } 1672 \\
\text { prowizja papieska } 20 \text { XII } 1672 \\
\text { zgon } 18 \text { IV } 1681^{24}
\end{array}
$$

Anno Domini 1672, die 9. Martii, in mei, notarii apostolici, praesentia, Reverendi Patres Fratres Andreas Zabledzki, prior, Albertus Wadowski, senior, Iacobus Zebrowski, provisor, Stanislaus Volski, paenitentiarius [dalej wyliczeni pozostali członkowie konwentu], professi archicoenobii Andreoviensis Ordinis Cisterciensis, totum et integrum capitulum repraesentantes [...], actum electionis [novi abbatis] inchoarunt [...] [et] omnium et singulorum eligentium uniformia voce [canonice electus est] Admodum Reverendus Dominus Stephanus Theodorus Madalinski,

\footnotetext{
${ }^{23}$ Folwarski, Poczet opatów klasztoru kanoników regularnych w Czerwińsku, s. $37-38$ (,zmarł 24 II 1681 r.").

${ }^{24}$ Bukowski, Katalog opatów jędrzejowskich, s. 202 („został wybrany 9 III 1672 r. na opata”; „,zmarł 18 IV 1681 r.”). Także: Liber mortuorum monasterii Andreoviensis Ordinis Cisterciensis, s. 771, 782 († 18 IV 1681); Liber mortuorum monasterii Landensis Ordinis Cisterciensis, s. $483(\dagger 19$ IV 1681); Monasticon Cisterciense Poloniae, t. 2, s. 92.
} 
conventus Landensis Ordinis Cisterciensis professus, [...] in abbatem monasterii Andreoviensis.

ASR, Paesi stranieri (sec. XVII-XVIII), Busta 12, fasc. 14, s. 424-425 nr 1 (Electio a monachis libere facta ad favorem R.P. Theodori Madalinski - dokument sporządzony przez notariusza publicznego Sebastiana Mitrzyńskiego).

Clemens episcopus, servus servorum Dei, dilecto filio Stephano Theodoro Madalinski, abbati monasterii abbatiae nuncupati Beatissimae Mariae de Andreovia Cisterciensis Ordinis, Cracoviensis dioecesis, salutem etc. Cum itaque monasterium abbatiae nuncupatum Beatissimae Mariae de Andreovia etc. per obitum Alexandri Denhoff vacaverit et vacet ad praesens, nos [...] de persona tua apostolica auctoritate tibi providimus teque in abbatem praeficimus. Datum Romae, apud S. Mariam Maiorem, anno Domini 1672, tertio decimo Calendas Januarii, scilicet 20. Decembris.

ASR, Paesi stranieri (sec. XVII-XVIII), Busta 12, fasc. 14, s. 429-430 nr 5 (Provisio apostolica). Zob. również: tamże, s. 256-258 nr 11 (Motus proprius Sanctissimi circa abbatiam Andreoviensem de anno 1681).

Andreoviensis abbatia, Ordinis Cisterciensis, Cracoviensis dioecesis, vacans per obitum illius commendatarii Alexandri Denhoff, presbyteri saecularis, reducta fuit in titulum per electionem factam a monachis nona Martii 1672 de persona regulari Patris Theodori Madalinski in abbatem, qui possessionem etiam adeptus fuit. Verum quia Andreas Olszowski, episcopus Culmensis, se intruserat absque ullo titulo in possessionem eiusdem abbatiae, sub praetextu nominationis regiae et iuris patronatus praetensi ad dictam abbatiam, ideo idem Pater Theodorus contra ipsum reportavit mandatum de manutenendo et sententiam exclusivam iurispatronatus regii [...]. Quam abbatiam postea ipse episcopus obtinuit in commendam [...]. Postmodum anno 1672, 20. Decembris, idem Pater Theodorus obtinuit literas provisionis apostolicae in forma gratiosa cum expressa narrativa dictae commendae [...], novam possessionem accepit 27. Januarii 1673. Cum autem contra hanc provisionem dictus episcopus, etiamsi literas non reportaverit ad corrigendum [...], sententiam super immissione in possessionem eiusdem abbatiae reportaverit ab executore episcopo Cracoviensi 17. Februarii 1673, et illius vigore, non citato abbate possessore abbatiae, in possessionem se mittere fecerit eodem anno 20. Martii [...], dum autem [...] obierit idem [Andreas Olszowski, nunc] archiepiscopus [Gnesnensis], statim impedita fuit possessio dicto Patri Theodoro per episcopum Cracoviensem, qui propria auctoritate deputavit oeconomum pro administratione bonorum dictae abbatiae ac si vacaret, eamque etiam coepit praetendere vigore asserti iurispatronatus et regiae nominationis Illustrissimus Dominus Constantinus Lipski, archiepiscopus Leopoliensis. Non tamen potuit obtinere literas apostolicas super commenda eiusdem abbatiae, [...] [nam] papa Innocentius X [...] motu proprio declaravit dicti Theodori titulum verum et legitimum esse, ita ut ab omnibus in abbatem dicti monasterii Andreoviensis recognosceretur ipseque 
possessionem dicti monasterii vigore literarum apostolicarum super provisione huiusmodi expeditarum, assequeretur, et quatenus illam assecutus fuerit, in eam remaneret libere et licite. [...] Obiit dictus Pater Theodorus Madalinski, abbas, die 18. Aprilis 1681, post cuius obitus provisus fuit a Sede Apostolica in abbatem eiusdem monasterii Pater Joannes Kostecki, monachus [...].

ASR, Paesi stranieri (sec. XVII-XVIII), Busta 12, fasc. 14, s. 184-187. Zob. rownież: ASV, Miscellanea, Armadia I, vol. 84, k. 369r-370r nr 11 (Motus proprius Sanctissimi circa abbatiam Andreoviensem de anno 1681).

\section{Małowieski (Małowiecki) Adam Jan opat (Czerwińsk)}

prowizja papieska 22 XI 1690 zgon 2 III $1694^{25}$

Czervinensis abbatia Canonicorum Regularium Congregationis Lateranensis, Plocensis dioecesis, vacans per promotionem illius commendatarii Illustrissimi Domini Boguslai Lesczinski [Leszczyński] ad episcopatum Luceoriensem, concessa fuit in titulum Patri Nicolao Wyzycki, canonico regulari eiusdem Ordinis [...], expeditis literis apostolicis [...] sub datum: anno 1690, decimo septimo Kalendas Septembris. Eodem tempore concessa pariter in titulum tanquam liberae collationis Patri Adamo Maloviecki, eiusdem monasterii priori, expeditis literis apostolicis [...] sub datum: anno 1690, decimo Kalendas Decembris. Inter quos pendet lis in Rota [Romana] super executione utriusque provisionis.

ASR, Paesi stranieri (sec. XVII-XVIII), Busta 12, fasc. 14, s. 196-197.

Die 2 ${ }^{\text {da }}$ Martii. [Obitus] Perillustris ac Reverendissimi Domini Adami Joannis Małowieski, Canonicorum Regularium Lateranensium abbatis Cervenensis, provisi apostolici, decani et praepositi Błonensis, qui obiit anno 1694to sepultusque est in tumulo abbatiali.

BKSC, Liber mortuorum [abbatiae] Czervenensis, s. 118.

Mąkowski Adam komendatoryjny opat (Jędrzejów)

prezenta królewska 23 I 1623 elekcja 27 II $1623^{26}$

${ }^{25}$ Folwarski, Poczet opatów klasztoru kanoników regularnych w Czerwińsku, s. 39-41 (zgon 2 III 1694).

${ }^{26}$ Bukowski, Katalog opatów jędrzejowskich, s. 197 („,mianowany został koadiutorem opata [Bartłomieja] Powsińskiego przed 30 I 1622 r. [...] Po śmierci Powsińskiego otrzymał upragnione opactwo jędrzejowskie, pojawiły się jednak trudności z elekcją, spowodowane przez wikariusza generalnego polskiej prowincji cysterskiej Adama Trebnica. Po dokonanej 27 II 1623 r. wizytacji klasztoru [...] wezwał on, aby wybrano opata zakonnego. Klasztor ustąpić jednak musiał wobec 
Religiosi Patres et Fratres Joannes Białobrzeski, prior, Martinus Korczyn, provisor, Martinus Karniowski, bursarius, totusque conventus monasterii Andreoviensis, pro futuro abbate Andreoviensi capitulariter congregati, licet in primis optaverint, et secundum regula et instituta monasterii, vacantis per mortem Bartholomaei Powsinski, abbas professus eligeretur, [...] quia tamen Sacra Regia Maiestas voluntatem suam per literas declaravit, commendans Admodum Reverendum Dominum Adamum Mąkowski, suum in Regno Neapolitano internuntium, ut eum in abbatem postularent, [...] eundem Admodum Reverendum Dominum Adamum Mąkowski per vota secreta, postulandum esse a Sede Apostolica concorditer decreverunt et postulant, ita tamen, ut non ad vitam, sed ad quinquennium proximum commendam obtineat. [...] Datum Andreoviae, die 27. Februarii anno Domini 1623.

ASV, Segreteria di Stato. Polonia, Add. 4, b.p. (dokument wyboru Adama Mąkowskiego na opata przez konwent cystersów w Jędrzejowie); zob. również: tamże, b.p. (pismo króla Zygmunta III Wazy do konwentu jędrzejowskiego w związku z udzieleniem przez monarchę Adamowi Mąkowskiemu prezenty na opactwo, z daty: Warszawa, 23 I 1623 r.); ASR, Paesi stranieri (sec. XVII-XVIII), Busta 12, fasc. 14, s. 457-458 nr 37 (dokument prezenty królewskiej Zygmunta III Wazy dla Adama Mąkowskiego na opactwo jędrzejowskie z daty: Warszawa, 23 I 1623); zob. również: tamże, s. 458 nr 38 („Andreoviae, 27. Februarii 1623”; w dokumencie tym mowa od razu o aprobacie ze strony ordynariusza loci).

\title{
Mirecki Krystyn Stanisław opat (Święty Krzyż)
}

\author{
elekcja 29 XI 1689 (10 I 1690) \\ konfirmacja 9 VI $1690^{27}$
}

Sanctae Crucis abbatia in Calvo Monte, Ordinis S. Benedicti, Cracoviensis dioecesis, vacans per obitum Michaelis Hieronymi Komornicki, abbatis regularis, se-

woli królewskiej i dokonał elekcji Mąkowskiego"); R. Skowron, Opat dyplomata. Przypadek Adama Mąkowskiego, w: Cystersi w Jędrzejowie. Rola klasztoru w społeczności lokalnej, red. K. Ślusarek, Jędrzejów 1999, s. 76 („W czasie pobytu w Hiszpanii, po śmierci opata Powsińskiego, Mąkowski został mianowany opatem komendatariuszem cystersów w Jędrzejowie. [Miejscowy] konwent dokonał wyboru Mąkowskiego na opata komendatariusza między 27 II a 23 III 1623 r. Dalsza kwerenda, zwłaszcza [...] akt związanych z wizytacją Adama Trebnica, winna doprowadzić do ustalenia dokładnej daty jego wyboru”; por. s. 72: „Z Barcelony udał się [Mąkowski] do Madrytu, gdzie przybył 21 I 1623 r.”, czyli w dniu udzielenia mu prezenty na opactwo w Jędrzejowie przez polskiego monarchę). Nadto: Liber mortuorum monasterii Andreoviensis Ordinis Cisterciensis, s. 771.

${ }^{27}$ Gacki, Benedyktyński klasztor Świętego Krzyża na Łysej Górze, s. 99 („,roku 1689 Stanisław Krystyn z Mirzec Mirecki przez zakonników [opatem] obrany, ale niedopuszczony przez Wyhowskiego do rządów, udał się do Rzymu dnia 20 VI 1693 r. i tam, za papieża Innocentego XII, dnia 28 X 1694 r. na opata poświęcenie otrzymał"). Także: Wiśniewski, Dekanat opatowski, s. 467; M. Kanior, P. Sczaniecki, Mirecki Stanisław, imię zakonne Krystyn, herbu Szeliga (1659-1733), benedyktyn, opat świętokrzyski, twórca polskiej kongregacji benedyktyńskiej, w: Polski słownik biograficzny, t. 21, Wrocław-Warszawa-Kraków-Gdańsk 1976, s. 338-339; Kanior, Polska Kongregacja Benedyktyńska, wg indeksu. 
cutum die 26. Septembris 1689, collata fuit in titulum per Sedem Apostolicam, praevia monachorum electione, capitulariter et libere facta die 29. Novembris eiusdem anni, [...] Patri Christino Mirecki, monacho eiusdem monasterii, sacrae theologiae lectori (minime attenta instantia Reverendissimi Domini Alexandri Wykowski [Wyhowski], canonici Plocensis, presbyteri saecularis, praesentati ad illam a serenissimo rege [...] cum onere suscipiendi habitum et profitendi eorum regulam, in quantum eligeretur prius in abbatem), expeditis literis apostolicis super confirmatione eiusdem electionis [...] sub datum: Romae, anno 1690, quinto Idus Junii.

ASR, Paesi stranieri (sec. XVII-XVIII), Busta 12, fasc. 14, s. 195. Zob. również: tamże, s. 278279 (dotyczy elekcji nowego opata w miejsce zmarłego Michała Hieronima Komornickiego, naznaczonej przez biskupa krakowskiego Jana Małachowskiego na dzień 29 XI 1689, a następnie - powtórnie - na dzień 10 I 1690, do udziału w której delegowani zostali przez ordynariusza loci kanonicy katedralni z Wawelu: Krzysztof Tarnowski, Kazimierz Łubieński oraz Teodor Potocki), 288-290 nr 7B (Literae apostolicae confirmationis electionis Patri Mirecki, in forma gratiosa expeditae, anno 1690, quinto Idus Junii).

Mocki Jerzy tytularny opat (Żótkiew)

benedykcja 1 I $1743^{28}$

1 ma Januarii 1743, Żółkiew. [...] Jmć xiądz arcybiskup lwowski [Mikołaj Ignacy Wyżycki], wczoraj tu przybyły, jedenastu instalował kanoników i samego - iuxta bullam pontificis - benedykował proboszcza Jmci xiędza Jerzego Mockiego na opactwo z wielką pompą i strzelaniem; assistentes byli Jmć xiądz sufragan łucki [Hieronim Antoni Szeptycki] i biskup zenopolitański [Jerzy Maria Lascaris].

AGAD, Dział VI, II-80a, s. 1221.

Naramowski Jerzy opat (Koronowo)

intromisja 2 III 1673

prowizja papieska 15 IV 1673

zgon 4 I $1685^{29}$

Coronoviensis abbatia, Ordinis Cisterciensis, Vladislaviensis dioecesis, vacans per obitum Petri Dembinski, abbatis regularis, fuit ad eamdem abbatiam electus in abbatem a monacis Georgius Naramovski, monachus eiusdem Ordinis, et immissus in possessionem die 2. Martii 1673, et successive ex abundanti obtinuit pro

${ }^{28}$ S. Barącz, Pamiątki miasta Żółkwi, Lwów 1877, s. 164, 168 (tytularnym opatem J. Mocki został 26 V 1742, zmarł 9 XII 1747).

${ }^{29}$ Series abbatum coenobii Byszoviensis seu Coronoviensis Ordinis Cisterciensis, s. $817 \mathrm{nr} 35$; Liber mortuorum monasterii Coronoviensis O.Cist., s. 12 (5 I 1695); Wypisy źródtowe do biografii polskich biskupów, cz. 11, s. $381 \mathrm{nr} 28$. 
parte sua, in forma gratiosa, literas apostolicas super eadem abbatia, tamquam liberae collationis, sub datum: Romae 1673, 17. Kalendas Maii. [...] Verum quia Ignatius Gninski, presbyter saecularis, praesentatus a rege ad eamdem abbatiam, obtinuerat mandatum a Sede Apostolica directum domino nuncio apostolico, ut dicto monasterio quatenus de iurepatronato regio existeret, et quod electio praefata Georgii minus canonice facta et successive per sententiam nuncii apostolici auditoris nulla et invalida declarata fuerit, providisset eidem Ignatio in titulum (postquam tamen ipse prius habitum suscepisset et professionem emisisset) ac ipsum illi in abbatem praeficisset, ut in literis apostolicis desuper expeditis sub datum: Romae 1673, 12. Kalendas Octobris. [...] Deinde mortuo dicto Georgio abbate 4. Januarii 1685, statim dictus Ignatius, presbyter saecularis, adversarius, porrexit supplicationem Sanctissimo pro concessione subrogationis gratiosae, $[\ldots]$ sed fuit reiecta eius instantia, tum ex quo se intruserat in possessionem dictae abbatiae, quam legitime possidebat dictus Georgius, [...] tum ex quo dictus Ignatius tam ante attentam possessionem quam post non assumpserat habitum regularem, iuxta formam dictorum literarum apostolicarum sibi concessarum [...]. Et postea dicta abbatia, post mortem dicti Georgii vacans, fuit collata [...] Patri Felici Lacki, monacho dicti Ordinis, et supplicatio fuit data anno 1685, pridie Idus Maii. Sed iste timens litem cum dicto Ignatio, dimissit eandem abbatiam in manibus papae per suum procuratorem. Unde idem Ignatius, postquam assumpsit habitum et expleta probatione novitiatus per annum, emisit professionem regularem, assumpto nomine Bernardi, obtinuit eandem abbatiam [...], expediti literis apostolicis in forma gratiosa, sub datum: anno 1686, sexto Kalendas Augusti.

ASR, Paesi stranieri (sec. XVII-XVIII), Busta 12, fasc. 14, s. 189-191. Zob. nadto: tamże, s. 29 $\S$ XII (,Monasterium Coronoviense, dioecesis Vladislaviensis. Quod vacante per obitum abbatis regularis, a Sede Apostolica provisum mense Maii 1685 fuit de alio abbate regulari P.D. Felice Lacki”).

Ostaszewski Beda opat (Lubin)

elekcja 17 IV 1815

konfirmacja 8 VI $1816^{30}$

[In capitulo electionis abbatis claustralis Lubinensis] post fata olim Reverendissimi Domini Nicolai Stanislai Kieszkowski, immediati abbatis, qui anno Domini $1814^{\text {to }}$, die XVIII. Octobris, vitam cum aeternitate commutavit, [...] quoniam multo maior pars votorum in personam Perillustris Reverendissimi Domini Bedae Ostaszewski, sacrae theologiae doctoris, monasterii Plocko-Pultoviensis prioris, ibidemque vacantis abbatiae administatoris, Ravae ad ecclesiam Sancti Spiritus

${ }^{30}$ Kanior, Polska Kongregacja Benedyktyńska, s. 243, 252-253, 255; Nowowiejski, Ptock. Monografia historyczna, s. $554 \mathrm{nr}$ 41. Nadto: Liber mortuorum monasterii Lubinensis Ordinis Sancti Benedicti, wyd. W. Kętrzyński, w: Monumenta Poloniae Historica, t. 5, s. 602; Teki Dworzaczka: Metrykalia>Katolickie>Część 4 • nr 26556 (Benedyktynki poznańskie); Część 8 • nr 50985 (Lubin). 
praepositi, viri in Congregatione emeriti, in praeterito capitulo generalis praesidentis, regularis observantiae zelo, animi dexteritate, in administratis officiis, nempe: unum triennium subprioris, per quinque triennia in suo monasterio PlockoPultoviensi prioris, fidelitate, generis nobilitate, vitae morumque honestate, aliisque dotibus ab annis triginta et uno suae professionis religiosae commendati confluxisse, adeoque canonicam electionem in eundem extitisse patuit. [...]

[Et] ego infrascriptus praesentatum mihi supra exaratum actum electionis seu verius postulationis in personam mei [...] acceptavi, illique me summisi, die hac $29^{\text {na }}$ mensis Aprilis anno currenti 1815o. Beda Ostaszewski OSB, monasterii PlockoPultoviensis professus.

ASV, Archivio Concistoriale, Congregationis Consistorialis Acta, 1814-1817, k. 259r-260v (Actus electionis novi abbatis claustralis perpetui monasterii Lubinesis post fata Reverendissimi Domini Nicolai Stanislai Kieszkowski, anno Domini 1815, die 17. Aprilis, expeditus).

Quum per obitum Reverendissimi Patris Nicolai Stanislai Kieszkowski vacaverit abbatia claustralis monasterii Lubinensis sub titulo Nativitatis Beatissimae Mariae Virginis Ordinis S. Benedicti Posnaniensis dioecesis, et monachi eiusdem monasterii capitulariter congregati in illius locum per secreta suffragia elegerint Reverendum Patrem Bedanum Ostaszewski, monachum praefati monasterii expresse professum, qui humiliter Sanctissimo Domino Nostro supplicavit, ut hanc sui electionem approbare et confirmare dignaretur, idem Sanctissimus Dominus Noster [...] huiusce electionis instrumento attente inspecto, praefatum Reverendum Patrem Bedam Ostaszewski in abbatem claustralem monasterii Lubinensis sub titulo Beatissimae Mariae Virginis Ordinis Sancti Benedicti Posnaniensis dioecesis benigne confirmavit mandavitque expediri decretum [...]. Datum Romae, hac die 8. mensis Junii 1816.

ASV, Archivio Concistoriale, Congregationis Consistorialis Acta, 1814-1817, k. 255r-v (1816, die 8. Junii. Posnaniensis. Monasterii Lubinesis confirmationis electionis); całość - k. 254r $-262 \mathrm{v}$.

\section{Powsiński Barttomiej komendatoryjny opat (Jędrzejów) prowizja papieska 11 IX $1600^{31}$}

Cum sicut accepimus monasterium Andreoviense Cisterciensis Ordinis, dioecesis Cracoviensis, quod quondam Dominus Stanislaus Rescius [...] obtinebat, per obitum dicti Stanislai vacaverit et vacet, nos dilecto filio Bartholomaeo Powszynski,

${ }^{31}$ J. Choińska-Mika, Powsiński Bartłomiej herbu własnego (ok. 1568-1622), kanonik laterański i krakowski, opatjędrzejowski, dyplomata, w: Polski słownik biograficzny, t. 28, Wrocław-WarszawaKraków-Gdańsk-Łódź 1984-1985, s. 286-287; Bukowski, Katalog opatów jędrzejowskich, s. 196 („Opactwo [jędrzejowskie] uzyskał dzięki poparciu papieża Klemensa VIII, który 8 IV 1600 r. pisał w tej sprawie do króla"). Nadto: Liber mortuorum monasterii Andreoviensis Ordinis Cisterciensis, s. 771,798 . 
clerico Cracoviensi, cubiculario intimo et familiari continuo commensali nostro, quem dilecti filii conventus monasterium eiusdem [...] dicti monasterii abbatem postulaverunt, specialem gratiam facere volentes, motu simili monasterio praefato de persona eiusdem Bartholomaei, etiamsi ipse habitum per monachos eiusdem Ordinis gestari solitum non susceperit et professionem per eosdem emitti solitam non emiserit, providemus ipsumque illi in abbatem praeficimus [...]. Datum Romae, apud S. Marcum, 3. Idus Septembris anno 1600.

ASV, Segreteria di Stato. Polonia, Add. 4, b.p. (prowizja ze strony papieża Klemensa VIII na opactwo cystersów w Jędrzejowie dla Bartłomieja Powsińskiego); toż w: ASR, Paesi stranieri (sec. XVII-XVIII), Busta 12, fasc. 14, s. 456-457 nr 35 (Provisio apostolica abbatiae Andreoviensis per mortem Stanislai Rescii ad favorem Bartholomaei Powszynski, ad postulationem monasterii, cum dispensatione habitum non assumendi; zob. również: tamże, s. $457 \mathrm{nr}$ 36).

Radoszowska (Radoszewska) Elżbieta ksieni (Nieśwież)

profesja 21 XI 1632 zgon 30 I $1688^{32}$

Elżbieta Radoszowska, rodzona w lat 14 tegoż dnia, do zakonu profesję uczyniła w dzień Ofiarowania Najświętszej Panny 21 listopada 1632. Bywszy szostą ksienią lat 7, dni 34, umarła roku 1688 , dnia 30 . Januarii, w nocy o godzinie dwanastey.

AGAD, Archiwum Warszawskie, Radziwiłłów, Dział VIII, 353, s. 10 nr 104.

Radziwitłówna Krystyna Eufemia ksieni (Nieśwież)

wstapienie do zakonu 2 VII $1614^{33}$

Krystyna Euphemia Radziwiłłowna, xiężna na Ołyce i Nieświeżu, starościanka żmoydzka, ta w ósmym roku [życia] dana do klasztoru, wstąpiła do zakonu mając lat 16 dnia 2 lipca 1614. Ksieni 3 [trzecia].

AGAD, Archiwum Warszawskie, Radziwiłłów, Dział VIII, 353, s. 6 nr 50.

Reszka Stanisław komendatoryjny opat (Jędrzejów)

prezenta królewska $13 \times 1585$

elekcja 1 XI 1585

\footnotetext{
${ }^{32}$ Borkowska, Stownik polskich ksień, s. 131-132; taż, Leksykon zakonnic polskich, t. 3, s. 92.

${ }^{33}$ Borkowska, Stownik polskich ksień, s. 134; taż, Leksykon zakonnic polskich, t. 3 , s. 88.
} 
Stephanus, rex Poloniae, etc., Venerabili Stanislao Rescio [...]. Mortuus est nuper abbas Andreoviensis Stanislaus Bialobrzeski [...]. Abbatia, quam habuit, satis amplos habet reditus, [propterea] de ea abbatia scripsimus ad reverendissimum dominum episcopum Cracoviensem, ut ipse, si potiri ea abbatia velis, procuret pro sua loci ordinarii potestate, ut a monachis eligaris. [...] Scribimus etiam ad convento Andreoviensi, summa cum diligentia commendando personam vestram, ut vota et sententias in favorem Dominationis Tuae conferant. [...] Varsaviae, 13. Octobris 1585 .

ASV, Segreteria di Stato. Polonia, Add. 4, b.p. (królewska prezenta na opactwo jędrzejowskie dla Stanisława Reszki z daty: Warszawa, 13 X 1585).

Per hoc publicum instrumentum cunctis pateat evidenter, quo modo anno 1585, die 1. Novembris, [...] Venerabiles Fratres Petrus Borowski, abbas Sciricensis, quoad actum infrascriptum ad praesidendum adscitus, Stanislaus prior, Martinus custos, caeterique fratres conventus monasterii Andreoviensis dioecesis Cracoviensis, ad sonum campanae congregati [...], sub conditionibus per conventum praefatum porrectis super suscipiendo habitu regulari professioneque in Ordine emittenda, in futurum abbatem et praelatum suum Reverendissimum Dominum Stanislaum Rescium nominaverunt, elegerunt, postulaverunt et irrevocabiliter declaraverunt.

ASV, Segreteria di Stato. Polonia, Add. 4, b.p. (dokument notarialny, poświadczający elekcję Stanisława Reszki w dniu 1 XI 1585 r. przez konwent cystersów w Jędrzejowie na opata); toż w: ASR, Paesi stranieri (sec. XVII-XVIII), Busta 12, fasc. 14, s. 455-456 nr 33 (Electio a monasterio libere facta de persona [Stanislai] Rescii per obitum Stanislai Bialobrzeski anno 1585 - dokument sporządzony przez notariusza publicznego Piotra Goyskiego); tamże, s. 456 nr 34 (Confirmatio dictae electionis, facta per generalem Ordinis sub conditione emittendi professionem - dokument opata Citeaux Edmunda á Cruce z daty: Cistercium, 5 X 1586).

D. O. M. Stanislao Rescio, protonotario et utriusque signaturae referendario apostolico, Andreoviensi abbati, viro ingenii, laude, doctrina, fide, moribus celeberrimo, qui Romae carus omnibus et magno in primis Hosio cardinali, a Stephano I. Poloniae rege revocatus ex Urbe, mox apud Sixtum V. Pontificem Maximum legatione functus, demum Neapoli Sigismundi III. negotiis occupatus, obiit de hac aede potissimum optime meritum, cui sua olim auctoritate fundatae sacelli domestici supellectilem sacram decem item loca Montium Novennalium empta cum usufructu noscomio ad subsidium peregrinorum atque ordinarii sacerdotum lega-

${ }^{34}$ Bukowski, Katalog opatów jędrzejowskich, s. 196 (,nominację otrzymał od króla 22 V 1585 r.”); T. Chrzanowski, M. Kornecki, Polskie pomniki w świątyniach Rzymu, Warszawa 1994, s. 81-82 (nr 22). Nadto: Liber mortuorum monasterii Andreoviensis Ordinis Cisterciensis, s. 771; A.J. Kalinowska, Reszka (Rescius, Reski) Stanistaw (1544-1600), ksiadz, sekretarz i biograf kardynata Stanisława Hozjusza, dyplomata, opat jędrzejowski, pisarz, w: Polski słownik biograficzny, t. 31, Wrocław-Warszawa-Kraków-Gdańsk-Łódź 1988-1989, s. 129-133; Słownik biograficzny kapituły warmińskiej, oprac. zbior., Olsztyn 1996, s. 202. 
vit. Anno Jubilaei MDC, aetatis LII, Nonas Aprilis sepultus ad S. Mariae de Gratia. Orate Deum pro anima ipsius. Nicolaus Mieleczki et Fabian Konopaczki, huius templi oeconomi, posuerunt anno MDCI, mense Aprili.

V. Forcella, Iscrizioni delle chiese e d'altri edifici di Roma dal secolo XI fino ai nostri giorni, t. 13, Roma 1879, s. 438 nr 1057. Zob. również: ASR, Paesi stranieri (sec. XVII-XVIII), Busta 11, fasc. [1], Oggetto [IV], s. 19-25 (pod datą 7 IV 1600): Copia ultime voluntatis seu testamenti in scriptis, sigillati et facti Neapoli, die quinto mensis Martii anni 1600, per Illustrissimum et Reverendissimum Dominum Stanislaum Rescium, Pollonem [sic!], internuntium serenissimi regis Poloniae, et per ipsum internuntium subsecutum obitum aperto et publicato dicto testamento nomine reverende Camere Apostolice Neapoli die tertio mensis Aprilis eiusdem anni 1600 (tamże, s. 19-20, dyspozycja odnośnie do pochówku: „Corpus hoc terrenum terre redatur, sepelliatur more et usu in Ecclesia Dei, in templo Sancte Marie de Gratia, in quocunque templi loca voluerint. [...] Supra corpus lapis simplex super ponatur cum hac sola inscriptione: «Hic iacet peccator Stanislaus Rescha [sic!] de Buk, Pollonus presbiter. Oretur Dominus pro anima defuncti. Vixit annos quinquaginta septem. Obiit die \&»; s. 21: „Cistam de nuce cum scripturis regiis et libris computorum dominis executoribus diligenter commendo, et inprimis Illustrissimo Domini Aldobrandino, nuntio apostolico, ut eam obsignatam apud se conservetur usque ad informationem serenissimi regis mei. Libros, quo Cracoviae, apud S. Barbaram, in domo Societatis Jesu professa, deposui ad servandam, dono et lego eidem Societatis"; s. 22: „Executores retroscritti testamenti assigno et nomino Illustrissimum et Reverendissimum Dominum Aldobrandinum, nuntium apostolicum, Illustrissimum Dominum Ferrantem Furnaro, regentem, Reverendissimum Dominum Stanislaum Ruisky, canonicum Posnaniensem [...], et Dominum Adamum Rescha [sic!], pronepotem meum").

\section{Rostkowski Piotr komendatoryjny opat (Mogilno)}

elekcja 4 XII $1690^{35}$

Anno 1690, die 4. Decembris, celebratum est capitulum electionis in monasterio Mogilnicensi Ordinis S. Benedicti, in quo [praesente] Alberto Stawowski, episcopo Petrensi, et Francisco Zorawski, ab Eminentissimo Domino Michaele cardinali Radziejowski, archiepiscopo Gnesnensi, tanquam ordinario loci, ad praesidendum in electione novi abbatis seu administratoris pro dicto monasterio Mogilnicensi fienda, post obitum et mortem Nicolai Zabicki, abbatiae Mogilnicensis perpetui administratoris, vacantis, [deputatibus, capitulariter congregati patres et fratres dicti monasterii] in perpetuum administratorem abbatiae Mogilnicensis Reverendissimum Dominum Petrum Rostkowski, canonicum Varmiensem, virum [...] de legitimo matrimonio ac parentibus catholicis procreatum, $[\ldots]$ in sacerdotio constitutum, bonis moribus ornatum, pacificum et quietum, de Ecclesia et Republica bene meritum, [...] elegerunt.

${ }^{35}$ Słownik biograficzny kapituły warmińskiej, s. 207. Nadto: Suffragia monasterii Mogilnensis Ordinis Sancti Benedicti, wyd. W. Kętrzyński, w: Monumenta Poloniae Historica, t. 5, s. 660; Liber mortuorum monasterii Lubinensis Ordinis Sancti Benedicti, s. 606. 
ASR, Paesi stranieri (sec. XVII-XVIII), Busta 11, fasc. 3, s. 149-150 (tamże, s. 149, prezenta królewska z 19 X 1690 na wakującą po śmierci Mikołaja Żabickiego („Nicolaus a Radzanow Zabicki”) opactwo mogileńskie, które otrzymał „Venerabilis Petrus Rostkowski, custos cathedralis Culmensis, canonicus Varmiensis"; tamże, s. 151-153, suplika konwentu mogilneńskiego do papieża z prośbą o zatwierdzenie zaistniałego wyboru).

\section{Rozrażewski (Rozdrażewski) Jan Antoni komendatoryjny opat (Lubin) prezenta królewska 30 XI $1697^{36}$}

Hucusque suo possessore orbata abbatia Lubinensis religiosorum Ordinis Sancti Benedicti desiderat, qui ei sua opituletur tutelae. Quampropter Venerabilem Antonium Rozrazewski, Varsaviensem canonicum, administrandae dictae abbatiae parem, antiquissima Regni huius clarum origine, praepondendum sensui et nominavi. Cui nominationi ut Sanctitas Vestra annuere et bene placito suo eam approbare dignetur, instantissime flagito. [...] Dabatur Cracoviae, die XXX mensis Novembris anno Domini MDCXCVII.

ASV, Segreteria di Stato. Polonia, Add. 21A, cz. 1, k. 191r (suplika króla Augusta II Wettyna do papieża Innocentego XII w przedmiocie obsadzenia lubińskiego opactwa benedyktynów).

Rozrażewski (Rozdrażewski) Pawet Marcin opat (Przemęt)

elekcja 24 IV $1731^{37}$

Anno Domini 1732, die 24. mensis Aprilis, hora decima matutina, post fata Reverendissimi Domini [Joannis Roberti] Bułakowski, abbatis Premetensis, immediate praeteriti, congregati $[\ldots]$ in capitulo fratres eiusdem conventus Premetensis Ordinis Cisterciensis, in dioecesi Posnaniensi, [...] praesidente Reverendissimo Domino Antonio Łukomski, abbate Landensi et commissario ac vicario generali [...], [elegerunt] in abbatem supradicti monasterii Premetensis Dominum Paulum Rozrazewski, priorem Suleioviensem.

ASV, Segreteria di Stato. Polonia, Add. 22, b.p. (instrument notarialny).

${ }^{36}$ Kanior, Polska Kongregacja Benedyktyńska, s. 52. Nadto: Liber mortuorum monasterii Lubinensis Ordinis Sancti Benedicti, s. 602, 607; Teki Dworzaczka: Metrykalia>Katolickie>Część $3 \bullet \mathrm{nr} 21209$ (Leszno); Część $6 \bullet$ nr 43684 (Lubiń).

${ }^{37}$ Liber mortuorum monasterii Coronoviensis O.Cist., s. 28 („,29. Octobris 1735. Reverendissimus Paulus Rozdrażewski, abbas Premetensis") oraz przyp. 1; Teki Dworzaczka: Grodzkie i ziemskie> Wschowa $>$ Czesść $3 \bullet 1527$ (Nr. 176) 1738; Metrykalia $>$ Katolickie $>$ Część $6 \bullet \mathrm{nr} 38383$ (Bledzew - cystersi) i nr 38495 (Obra - cystersi), gdzie informacja, że zmarł 30 X 1735 w czwartym roku rządów opackich. 
Skoroszewski Jerzy opat (Pelplin)

elekcja 1 VII 1688

konfirmacja 16 VI $1689^{38}$

Pelplinensis abbatia, Cisterciensis Ordinis, Vladislaviensis dioecesis, vacans per obitum Ludovici Los, abbatis regularis, secutum 27. Martii 1688, collata fuit in titulum praevia monachorum electione libere facta die 1. Julii eiusdem anni, Patri Georgio Skoraszewski, priori claustrali eiusdem monasterii, confirmata [autem] a Reverendissimo Patre Generali eiusdem Ordinis sub datum: Cistercii, 16. Junii 1689.

ASR, Paesi stranieri (sec. XVII-XVIII), Busta 12, fasc. 14, s. 195.

Stawianowska Kazimiera ksieni (Otobok)

benedykcja 28 VIII $1774^{39}$

Die 28. Augusti 1774, in monasterio Ołobocensi, Perillustris, Reverendissimus Dominus Joannes Szłodrski, monasterii Beatissimae Mariae Virginis de Premeto abbas, monasterii vero sanctimonialium Beatissimae Mariae Virginis de Ołobok Ordinis Cisterciensis commissarius delegatus, [benedixit in abbatissam Olobocensem] Reverendissimam electam Casimiram Sławianowska, excepto prius iuramento iuxta formam et praescriptum Sacri Concilii Tridentini.

ASV, Archivi delle Rappresentanze Pontificie, Varsavia, 117, k. 316r-317r (Instrumentum installationis et benedictionis - dokument notarialny z daty: Przemęt, 20 X 1774). Zob. również: tamże, k. 242r-v (pismo nuncjusza apostolskiego w Rzeczypospolitej Obojga Narodów, arcybiskupa Angelo Marii Duriniego, z daty: Warszawa, 8 III 1769): „Electio superiorissae praesidentis monasterii Olobocensis cum facultate et authoritate abbatissae [...] subsecuta fuerit in monasterio Olobocensi sub die prima mensis Februarii anni praesentis sub praesidentia Reverendissimi Patris Joannis Szołdrski, abbatis Premetensis [...]. Rite et legitime electa [est] in superiorissam praesidentem cum facultate abbatissae Reverenda Martianna Kwiatkowska, monialis professa dicti monasterii" (także k. 235r-240v; tytułem «prezydentki» M. Kwiatkowska posługiwała się ze względu na zaistniały w klasztorze spór i opozycję przeciwko jej elekcji, w konsekwencji wstrzymując się z przyjęciem benedykcji) ${ }^{40}$; k. 277r (list nowoobranej ksieni ołobockiej z daty: Ołobok, 26 IX 1773).

38 R. Frydrychowicz, Geschichte der Cistercienserabtei Pelplin und ihre Bau- und Kunstdenkmäler, Düsseldorf [1905], s. 109-110 nr 34 (elekcja 1 VI 1688, potwierdzenie przez opata generalnego 16 VI 1689); Teki Dworzaczka: Metrykalia>Katolickie>Część 6 • nr 38460 (Opaci pelplińscy).Także: Monasticon Cisterciense Poloniae, t. 2, s. 303.

${ }^{39}$ Borkowska, Leksykon zakonnic polskich, t. 1, s. 59 („,obrana ksienią w 1773, zmarła 30 IV 1779”). Także: Teki Dworzaczka: Metrykalia>Katolickie>Część $1 \bullet \mathrm{nr} 1541$ (Owińska - klasztor); Część $6 \bullet$ nr 38634 (Obra - cystersi) i nr 40412 (Przemęt).

${ }^{40}$ Por.: Liber mortuorum monasterii Coronoviensis O.Cist., s. 62 („29. Julii 1773 obiit in monasterio Ołobocensi Reverendissima ac Venerabilis soror Marcianna Kwiatkowska, praesidissa cum omnibus facultatibus abbatissae"; tamże przyp. 1). Szerzej o konflikcie w: Borkowska, Leksykon zakonnic polskich, t. 1, s. 59 . 
Sosnkowski Józef Frydygian opat (Czerwińsk)

Die $7^{\text {ma }}$ Junii. [Obitus] Reverendissimi [Domini] Josephi Sosnkowski, abbatis claustralis nostri Cervenensis ac praepositi Krasnensis, qui protracta infirmitate spatio octo mensium, explectis novemdecem annis ac sex mensibus in dignitate abbatiali, quadraginta uno a professione religiosa, grassante tunc penuria ac infelicitate temporum, sacramentis munitus transtulit se in meliorem vitam hac die, hora media decima antemeridiana, sepultusque in tumulo abbatiali, anno Domini $1795^{\text {to }}$.

BKSC, Liber mortuorum [abbatiae] Czervenensis, s. 213.

Suliński Zygmunt komendatoryjny opat (Przemęt)

elekcja 6 XI $1645^{42}$

Anno 1645, die Lunae 6. mensis Novembris, in monasterio Ordinis Sacri Cisterciensis conventus Premetensis dioecesis Posnaniensis [electus est in abbatem] post mortem olim Reverendissimi Domini Nicolai Suligostowski [praesentatus a rege] Reverendissimus Dominus Sigismundus Sulinski, canonicus Gnesnensis.

ASV, Miscellanea, Armadia I, vol. 84, k. 403v-405r nr 3A (Abbatia Premetensis. Electio abbatis in persona Domini Sigismundi Sulinski, facta de anno 1645).

Szaniawska Ludwika Scholastyka ksieni (Nieśwież)

wstapienie do zakonu 21 XI 1779

profesja $26 X I 1780^{43}$

Ludowika Scholastyka Szaniawska z województwa sędomirskiego, z ziemi opoczyńskiej, wstąpiła do zakonu mając lat 24 dnia 21 miesiąca Novembra 1779 roku. Profesję uczyniła 26 miesiąca Novembra 1780 roku. Xieni 13 [trzynasta].

${ }^{41}$ Folwarski, Poczet opatów klasztoru kanoników regularnych $w$ Czerwińsku, s. 72 („umarł w Warszawie dnia 7 VI 1795 r.”). Nadto: Gawarecki, Wiadomość o starożytnym klasztorze, s. 202.

42 J. Korytkowski, Prałaci i kanonicy metropolitalni gnieźnieńscy od roku 1000 aż do dni naszych, t. 4, Gniezno 1883, s. 40 (,zasłużywszy się dobrze królowi Władysławowi IV, po zgonie Mikołaja Dunina Suligustowskiego otrzymał od niego w roku 1646 opactwo przemęckie, na które - zrezygnowawszy z kanonii [gnieźnieńskiej] - w tymże roku się przeniósł i przyjął habit zakonny"). Nadto: Przemęt. Zarys dziejów, s. 108; Teki Dworzaczka: Grodzkie i ziemskie>Kościan> Inskrypcje 7291 (Nr. 301) 1646; Metrykalia $>$ Katolickie>Część $6 \bullet$ nr 38375 (Bledzew - cystersi); Monasticon Cisterciense Poloniae, t. 2, s. 348.

${ }^{43}$ Borkowska, Stownik polskich ksień, s. 158; taż, Leksykon zakonnic polskich, t. 3, s. 105. 
AGAD, Archiwum Warszawskie, Radziwiłłów, Dział VIII, 353, s. 26 nr 284; zob. również: tamże, Dział VIII, 354 (jako obrana ksieni klasztoru benedyktynek w Nieświeżu Scholastyka Szaniawska iuramentum wykonała na ręce biskupa mińskiego Jakuba Ignacego Dederki).

Ścierski (Ścirski) Jan Wawrzyniec opat (Hebdów)

konfirmacja 27 VII $1671^{44}$

Hebdoviensis abbatia, Ordinis Praemonstratensis, Cracoviensis dioecesis, vacans anno 1671 per obitum illius commendatarii, suffraganei Vilnensis, reducta fuit in titulum mediante electione monachorum, facta de persona Patris Joannis Scirski, confirmata praevio voto Sacrae Congregationis Consistorialis die 27. Julii 1671, reiecta instantia olim Andreae Olszowski, episcopi Culmensis et vicecancellarii Regni, qui praetendebat dictam abbatiam sibi concedi in commendam vigore nominationis regiae.

ASR, Paesi stranieri (sec. XVII-XVIII), Busta 12, fasc. 14, s. 197.

Tarnowski Jan arcybiskup (Lwów), komendatoryjny opat (Przemęt)

elekcja 18 XII 1654

Anno 1654, die 18. Decembris, [in abbatem] monasterii Ordinis Sacri Cisterciensis conventus Premetensis dioecesis Posnaniensis, morte Reverendissimi olim Domini Sigismundi Sulinski, eiusdem ultimi abbatis, vacantis, in praesentia Reverendissimi Domini Nicolai Dunin, abbatis Obrensis, commisarii generalis Ordinis eiusdem Cisterciensis, per viam scrutini [electus est a rege designatus] Illustrissimus ac Reverendissimus Dominus Joannes Tarnowski, archiepiscopus Leopoliensis.

ASV, Miscellanea, Armadia I, vol. 84, k. 405r-406r nr 4 (Abbatia Premetensis. Electio archiepiscopi Leopoliensis in commendatarium facta a monachis cum protestantibus anno 1654).

Trzebiński Aleksander komendatoryjny opat (Jędrzejów)

elekcja 3 I $1641^{45}$

${ }^{44}$ N. Backmund, Monasticon Praemonstratense id est historia circariarum atque canoniarum candidi et canonici Ordinis Praemonstratensium, t. 1, Straubing 1949, s. 340 nr 34 („Joannes Laurentius Scierski 1673-1691"). Zob. nadto: J. Wiśniewski, Dekanat miechowski, Radom 1917 [reprint: Kielce 2000], s. 33nn.

${ }^{45}$ Bukowski, Katalog opatów jędrzejowskich, s. 198 (,„3 I 1641 r. Jan Klemens Branicki przywiózł do klasztoru nominację Trzebińskiego na opactwo jędrzejowskie, z poleceniem dokonania elekcji królewskiego kandydata. 27 I tr. biskup krakowski Jakub Zadzik zatwierdził jego wybór"). Nadto: Liber mortuorum monasterii Andreoviensis Ordinis Cisterciensis, s. 771. 
Anno 1641, die vero tertia mensis Januarii, ad electionem futuri abbatis Andreoviensis, post obitum Illustrissimi Domini Remigii Koniecpolski, episcopi Chelmensis, dictae abbatiae ultimi possessoris [...], capitulariter congregati venerabiles patres et fratres dicti monasterii Andreoviensis, [...] visis et lectis Sacrae Regiae Maiestatis commendationis literis [...], de unanimi consensu in suum abbatem, superiorem et praelatum, cum ea tamen conditione, ut habitum religionis suscipiat professionemque emittat, Reverendissimum Dominum Alexandrem Trzebinski per secreta vota elegerunt et quilibet eorum libere elegit.

ASV, Segreteria di Stato. Polonia, Add. 4, b.p. (dokument notarialny, poświadczający wybór na opactwo jędrzejowskie Aleksandra Trzebińskiego); toż w: ASR, Paesi stranieri (sec. XVIIXVIII), Busta 12, fasc. 14, s. 459-460 nr 40 (dokument sporządzony przez notariusza publicznego Filipa Hintinusa; podczas wyboru Aleksandra Trzebińskiego reprezentował prokurator Wojciech Koryciński).

Wieszczycki Antoni Olegar opat (Czerwińsk)

zgon 7 III $1759^{46}$

Die $7^{\mathrm{ma}}$ Martii. [Obitus] Illustrissimi ac Reverendissimi Domini Antonii Ollegarii Wieszczycki, Canonicorum Regularium Lateranensium abbatis [Cervenensis] post exdivisionem bonorum abbatialium secundi, qui diuturno eoque dolorissimo morbo consumptus obiit hora septima mane in praedio Sielecensi anno $1759^{\text {no }}$.

BKSC, Liber mortuorum [abbatiae] Czervenensis, s. 118.

Wołowski Jan (w zakonie) Antoni opat (Czerwińsk)

elekcja 30 XI 1795

konfirmacja 19 I 1796

zgon 13 III [1803] ${ }^{47}$

Capitulum praesens [...] amorem et affectum in cordibus suis erga semel anteriori in capitulo electum in coadiutorem abbatiae Perillustrem Reverendissimum Antonium Wołowski, praepositum Zuzoliensem, immutabiliter gerens, eodemque zelo boni communio matris suae Congregationis compulsum, quod certo quaeque prospera, utilia ac proficua communitati opinandavint[?] in praedicto Perillustri Reverendissimo Antonio Wołowski, qui amantissimi patris Congregationis nomine gloriari meritis valet, non aliam normam electionis assumere se declaravit,

${ }^{46}$ Folwarski, Poczet opatów klasztoru kanoników regularnych w Czerwińsku, s. 58-60 („umarł 7 III 1759 r. w wieku 64 lat”). Nadto: Gawarecki, Wiadomość o starożytnym klasztorze, s. 208 (nr 8).

${ }^{47}$ Folwarski, Poczet opatów klasztoru kanoników regularnych w Czerwińsku, s. $72-74$ (elekcja 30 XI 1795, zatwierdzenie papieskie 27 I 1796, zgon 13 III 1803). 
quum vivae vocis oraculum, hocque modo electionem abbatis claustralis Cervenensis post mortem et obitum Reverendissimi Josephi Sosnkowski, abbatis sui, sub die septima Junii anno currenti subsecutum perficere, prout praescriptioni iuris convenientem singuli capitulares se se obtulerunt. Requisiti itaque singulorum capitularium consensu per perillustrem secretarium capituli super declarationem electionis abbatis claustralis Cervenensis, quem vellent eligere [...], viva, clara et intelligibili voce ter repetita omnes et singuli capitulares, nemine contradicente, vota et electionem suum oretenus in Perillustrem Reverendissimum Antonium Wołowski, praepositum Zuzoliensem, ante hac electum coadiutorem, contulerunt. Quapropter sic effectuata canonica electione, nullo obstante vel contradicente ex capitularibus, idem perillustris capituli secretarius requisivit num placeret capitulo taliter peractam electionem canonicam abbatis claustralis Cervenensis pro persona praedicti Perillustris Reverendissimi Antoni Wołowski, praepositi Zuzoliensis, publicare? Et recepto ab omnibus assensu, quod placeat, eandem electionem sic publicavit.

ASV, Archivio Concistoriale, Congregationis Consistorialis Acta, 1796-1799, k. 4r-6r (Plocensis, abbatiae claustralis Czervenensis, confirmationis electionis (19. Januarii 1796): k. 5r-6r (Electio abbatis claustralis Cervenensis); tamże, k. 4r: „Actum Cervenscii, in capitulo convocationis electionis abbatis claustralis Cervenensis et candidatorum ad praeposituram regularem parochialem Krasnensem Canonicorum Regularium Lateranensium Congregationis Cervenensis [...] die trigesima mensis Novembris anno Domini millesimo septingentesimo nonagesimo quinto").

Die 13. Martii. Hac die, hora septima matutina, obiit Illustrissimus Reverendissimus Joannes Antonius Wołowski, abbas claustralis Cervenensis, de stemmate Pruss. Vir antiquae prosapiae et rarae humanitatis, qui de praepositura Zuzoliensi (quam fere a fundamentis erexit) ad mitram pontificiam vocatus, sexto post sui installationem anno, aetatis vero suae 67 , morbo pthysis correptus et ad mortem bene dispositus, obdormivit in Domino in villa haereditaria fratris sui germani Lutomirzyn, parochiae Graleviensis.

BKSC, Liber mortuorum [abbatiae] Czervenensis, s. 129.

Wyżycki Mikołaj opat (Czerwińsk), biskup (Chetm/Krasnystaw) prowizja papieska 16 VIII $1690^{48}$

[zob. wyżej zapiskę odnoszącą się do Jana Adama Małowieskiego (Małowieckiego)]

ASR, Paesi stranieri (sec. XVII-XVIII), Busta 12, fasc. 14, s. 196-197.

${ }^{48}$ Folwarski, Poczet opatów klasztoru kanoników regularnych w Czerwińsku, s. 40-41. Nadto: Makarczyk, Procesy informacyjne, s. 247-248; taż, Polscy biskupi z Zakonu Kanoników Regularnych Laterańskich, „Echa Przeszłości” 8 (2007), s. 47-51 (zwł. s. 48). 
Suleoviensis abbatia, Ordinis Cisterciensis, Gnesnensis dioecesis, vacans anno 1677 per translationem quondam Stanislai Sarnovski, episcopi Premisliensis, ad Ecclesiam Vladislaviensem (qui dictam abbatiam obtinuerat in commendam, cum decreto revertendi in titulum, sub datum 1659, Idibus Julii), concessa fuit in titulum a Sede Apostolica in forma gratiosa, uti liberae collationis, Patri Bernardo Zaruski, priori eiusdem monasterii, sub datum: Romae 1677, 10. Kalendas Julii. Cuius provisionis apostolicae executio per multum tempus impedita fuit per Illustrissimum Dominum Joannem Sbascki [Zbąski], successorem episcopatum Premisliensem, qui praetendendo dictam abbatiam in commendam vigore nominationis regiae et iurispatronatus praetensi, instetit pro illius concessione in Congregatione Consistoriali $[\ldots]$, sed fuit ipsi denegata.

ASR, Paesi stranieri (sec. XVII-XVIII), Busta 12, fasc. 14, s. 187-189. Zob. również: tamże, s. 258-259 nr 12 (Motus proprius Sanctissimi circa abbatiam Suleoviensem de anno 1681); oraz s. $28 \S$ V („Monasterium Suleioviense, dioecesis Gnesnensis. Abbas regularis, provisus a Sede Apostolica 1677 in Julio, P.D. Bernardus Zaruski”).

\section{Ziółkowicz (Ziółkiewicz) Kazimierz opat-koadiutor (Szczyrzyc) prowizja papieska (koadiutoria) $12 \times 1668^{50}$}

Ciriciensis abbatia, Ordinis Cisterciensis, Cracoviensis dioecesis, vacans per obitum Premislai Domiechovski, abbatis regularis, fuit collata in titulum mediante monachorum electione libere facta anno 1684 Patri Nicolao Remiszowski, monacho eiusdem Ordinis. Et dictum Premislaus, abbas, longe ante suum obitum obtinuerat sibi a Sede Apostolica in coadiutorem Casimirum Zolkiewicz, sacrae theologiae doctorem, monachum eiusdem Ordinis, expeditis literis apostolicis super huiusmodi coadiutoria cum futura successione ad dictam abbatiam [...] sub datum: Romae 1668, quarto Idus Octobris, vigore quorum fuit in exercitio eiusdem

49 J. Wiśniewski, Dekanat opoczyński, Radom 1913 [reprint: Kielce 2000], s. 277, 279, 281; Monasticon Cisterciense Poloniae, t. 2, s. 322; M. Borkowska, Dzieje cystersów sulejowskich, Kraków 2008, s. 139-142 (,jesienią 1681 r. objął urząd opata").

${ }^{50}$ J.M. Marszalska, W. Graczyk, Opaci i przeorzy klasztoru OO. Cystersów w Szczyrzycu od XIII do XX wieku, Kraków 2006, s. 131 („,Pod koniec [sic!] w 1675 r. [opat Przemysław Domiechowski] mianował koadiutora w osobie o. Kazimierza Ziółkowicza, profesa klasztoru bledzewskiego, który po jego śmierci miał objąć urząd opacki. Plany te nie zostały zrealizowane, gdyż w 1682 r., a więc jeszcze na dwa lata przed śmiercią Domiechowskiego, król Jan III Sobieski [...] zamianował koadiutorem Mikołaja Romieszowskiego, herbu Jelita, dotychczasowego przeora w Szczyrzycu, profesa paradyskiego”), 133 („W czasie rządów opata Przemysława Domiechowskiego urząd koadiutora, od około 1670 r., pełnił Kazimierz Ziółkowicz, profes klasztoru w Bledzewie, proboszcz w Rokitnie i później w Jarocinie. Ziółkowicz był koadiutorem do 1682 r. Wówczas to króla Jan III Sobieski listem wydanym w Jaworowie 7 X 1682 r. polecił na ten urząd czterech kandydatów spośród zakonników szczyrzyckich: Romana Bernarda Kąckiego, Józefa Sąchockiego - podprzeora, Benedykta Kmitę i Mikołaja Romiszowskiego. Opatem koadiutorem został wybrany Mikołaj Romiszowski”). 
coadiutoriae idem Pater Casimirus, sed postea anno 1680 obiit longe ante ipsius coadiuti obitum.

ASR, Paesi stranieri (sec. XVII-XVIII), Busta 12, fasc. 14, s. 194-195.

Żaboklicki Walentyn Tomasz opat (Czerwińsk)

zgon 23 IV $1816^{51}$

Die 23 $3^{\text {tia }}$ Aprilis. Hodie, hora decima vespertina, anno Domini Nostri Jesu [Christi] 1816, in Borzęcin, bonis tenutariis, caecidit flos nostri honoris, Illustrissimus ac Reverendissimus Valentinus Thomas Nałęcz Zaboklicki, abbas claustralis Cervenensis, vir piissimus omnique virtutum genere praeditus, qui [...] ad infulas expetitus [sic!] eandem dignitatem annis fere 13 eximie est exequtus [sic!].

BKSC, Liber mortuorum [abbatiae] Czervenensis, s. 170. Por.: ASV, Archivio Concistoriale, Congregationis Consistorialis Acta, 1814-1817, k. 299r oraz k. 301r.

Żegocki Mikołaj opat (Przemęt)

zgon 29 XII $1689^{52}$

[zob. wyżej zapiskę dotyczącą opata Antoniego Kontskiego]

ASR, Paesi stranieri (sec. XVII-XVIII), Busta 12, fasc. 14, s. 193. Zob. nadto: tamże, s. 29 § I („Monasterium Praemetense, dioecesis Posnaniensis. Abbas regularis, electus 1662, P.D. Nicolaus Zegocki”).

$* * *$

\section{VARIA}

Batory Andrzej biskup (Warmia), komendatoryjny opat (Czerwińsk), kardynat zgon $31 X[1599]^{53}$

${ }^{51}$ Folwarski, Poczet opatów klasztoru kanoników regularnych w Czerwińsku, s. 74-76 (23 IV 1816).

${ }^{52}$ Przemęt. Zarys dziejów, s. 116 (,zmarł 29 XII 1689 r.”); Teki Dworzaczka: Metrykalia> Katolickie>Część $6 \bullet \mathrm{nr} 38410$ (Bledzew - cystersi); Monasticon Cisterciense Poloniae, t. 2, s. 352 (o epitafium); Nekrolog klasztoru cystersów w Paradyżu, s. 158 (tamże przyp. 158).

${ }^{53}$ Z. Szostkiewicz, Katalog biskupów obrządku łacińskiego przedrozbiorowej Polski, w: Sacrum Poloniae Millenium. Rozprawy - Szkice - Materiały historyczne, t. 1, Rzym 1954 [dalej cyt.: Szostkiewicz, Katalog], s. 412 (,,zamordowany na granicy Mołdawii 28 lub 31 X 1599”); P. Nitecki, Biskupi Kościoła w Polsce w latach 965-1999. Stownik biograficzny, Warszawa 2000², [dalej cyt: Nitecki, Biskupi], kol. 21 (28 X 1599). Także: Gawarecki, Wiadomość o starożytnym klasztorze, s. 
Die $31^{\text {ma }}$ Octobris. [Obitus] Serenissimi principis ac Reverendissimi domini cardinalis Batorei, administratoris canoniae nostrae [Czervenensis], episcopi Varmiensis et generalis praepositi Miechoviensis.

BKSC, Liber mortuorum [abbatiae] Czervenensis, s. 359.

\section{Bernatowicz Jan biskup (Kamieniec)}

Coram officio et actis praesentibus consitorii Leopoliensis [...] personaliter constitutus Reverendissimus Dominus Joannes Bernatowicz, episcopus Armenus, principalis, sane mente et corpore existens, omni meliori modo, via, forma, iure ac stylo, quo melius, firmius, validius et efficacius potuit ac debuit, recognovit [...], quod licet ipse alias ab Isaaco, episcopo Silensi schismatico, in episcopum Camenecensem ritus Armeni ordinatus fuerit, nihilominus volens ea, qua decet reverentia, se submittere Sanctae Sedi Apostolicae Romanae et eius dispositionibus parere, in signum filialis obedientiae, non coactus, non compulsus, neque alio quovis devio errore circumventus, sed palam, sponte, libere, nec ad alicuius suggestionem, h[uius]modi titulo episcopi et episcopatui Camenecensi ritus Armenorum renuntiavit, resignavit, cessit et a se abdicavit, nihil iuris praetextus, aut coloris sibi ad eundem titulum episcopi Camenecensis reservando, sed illud totaliter a se abdicando, prout et renuntiat, resignat, cedit, abdicat, submittens se Sanctae Sedi Apostolicae et Sacrae Congregationi de Propaganda Fide. Praesentibus Perillustri et Admodum Reverendis Gabriele Zachnowicz, officiali Armenorum, Onophrio Asłanowicz, custode sacrorum ecclesiae cathedralis Armenorum Leopoliensis, testibus ad praemissa omnia vocatis, rogatis et adhibitis.

Archiwum Archidiecezji Lwowskiej w Krakowie, K.K. 19[17], k. 203v (Resignatio episcopatus Armenorum Camenecensis. Die Mercurii trigesima 1 $1^{m a}$ mensis Augusti [1695]).

Bukaty Tadeusz Józef biskup (Żmudź)

narodziny 5 VIII 1740 chrzest 7 VIII $1740^{55}$

201-202; Folwarski, Poczet opatów klasztoru kanoników regularnych w Czerwińsku, s. 27 (28 X 1599); Prokop, Polscy kardynałowie, s. 98-99; Graczyk, Opaci kanoników regularnych z Czerwińska, s. 136; Jakubowski, Solarczyk, Organizacja Kościoła rzymsko-katolickiego na ziemiach polskich, s. 197, 243.

${ }^{54}$ G. Petrowicz, La Chiesa Armena in Polonia e nei paesi limitrofi, t. 3 - 1686-1954, Roma 1988, s. 2-7, 50.

${ }^{55}$ Szostkiewicz, Katalog, s. 422; Nitecki, Biskupi, kol. 44 (5 VIII 1740). Także: K.R. Prokop, "Diario Ordinario» oraz «Notizie» rzymskich drukarzy Cracas (Chracas) jako źródło informacji do dziejów hierarchii Kościoła katolickiego w Rzeczypospolitej Obojga Narodów u schytku epoki staropolskiej, „Archiwa, Biblioteki i Muzea Kościelne”, 90 (2008) s. 126. 
Dominus Thaddaeus Joseph Bukaty natus est ex legitimis parentibus, Generosis Dominis Benedicto Bukaty et Sophia Wolbekowna, filia iudicis terrestris Smolenscensis, anno Domini 1740, die 5. mensis Augusti, baptizatum vero est in ecclesia filiali Antoleptis[?] dicta Patrum Carmelitarum Discalceatorum [...] eodem anno, die vero septima eiusdem mensis, de bonis Komaryszki in districtu Vilkomiriensi sitis. Patrini fuere Generosi Domini Joannes Ryk cum Generosa Domina [brak imienia] Daniszewska, assistentibus vero Generosus Dominus Joseph Wolbeck, filius iudicis terrestris Smolenscensis, cum Generosa virgine Sophia Bukatowna.

ASV, Archivio Concistoriale, Processus Consistorialis, vol. 187, k. 386v.

\section{Chomiński Michat biskup (Żmudź)}

rezygnacja z sufraganii 22 XII $1775^{56}$

Praesenti publico instrumento resignationis cunctis pateat evidenter et sit notum, quomodo anno a Nativitate Domini millesimo septingentesimo septuagesimo quinto, die vero Veneris vigesima secunda mensis Decembris, Indictione Romana VIII, [...] coram me infrascripto actisque meis publici notariatus apostolici testiumque infra[scri]ptorum, ad id specialiter rogatorum et ahibitorum, praesentia, constitutus personaliter Reverendissimus Dominus Michael Chominski, episcopus Eleusinensis, suffraganeus et custos Samogitiensis atque cathedralis ecclesiae Vilnensis canonicus, sanus mente et corpore per Dei gratiam existens, principalis, palam, sponte et libere ac benevole verbisque disertis recognovit praesentibusque recognoscit, quod ipse post mature praehabitam inter se deliberationem quod propter distantiam loci a canonicatu Vilnensi, cuius personaliter residentia praerequiritur, et ipse comparens saepius consuevit, obligationibus vi eiusdem canonicatus in eadem ecclesia cathedrali adesse ad ecclesiam cathedralem Samogitiensem quadraginta fere miliaribus Polonicis sitam, facile et absque dispendio salutis pro adimplendo munere suffraganeali condescendere, et circa dictam ecclesiam cathedralem Samogitiensem residere nequeat, tum ex aliis rationibus animum suum promoventibus, suffraganeatui praedicto Samogitiensi (reservata sibi nihilominus $[\ldots]$ annua pensione [...]) renuntiandum esse duxit prout quidem sub beneplacito Sanctae Sedis Apostolicae, ac sub benignissima episcopi exercendorum pontificalium de consensu respectivorum loci ordinariorum facultate renunciat, resignat ac se a dicto suffraganeatu Samogiensi liberandum et exvinculandum postulat [...]. Praesentibus Perillustris Reverendissimo Domino Ignatio Oskierka, canonico cathedrali Vilnensi, et Admodum Reverendo Joanne Gasparo Grudzinski, actorum

${ }^{56}$ M. Wołonczewski, Biskupstwo żmujdzkie, Kraków 1898, s. 105 („od 1767 r. był sufraganem żmudzkim, [jednak] o pracach jego nie mogłem zebrać żadnych wiadomości"); Szostkiewicz, Katalog, s. 424 (brak informacji o rezygnacji z sufraganii); Nitecki, Biskupi, kol. 51 (brak informacji o rezygnacji z sufraganii) oraz s. 41* (,[sufragan] 1765-1803”); Jakubowski, Solarczyk, Organizacja Kościoła rzymsko-katolickiego na ziemiach polskich, s. 233 (,[sufragan] 1765-1803”). 
capituli Vilnensis notario, et Martino Statkowski, altarista ecclesiae Vilnensis Sancti Stephani, testibus ad praemissa rogatis, habitis et adhibitis. Acta haec sunt Vilnae in mea solita residentia [...]. Augustinus Dembrowski, sacrae theologiae et iuris utriusque doctor, sancta authoritate apostolica publicus et actorum consistorii generalis Vilnensis notarius.

ASV, Archivio Concistoriale, Processus Datariae 153, k. 114r-v (12 IV 1776).

Gintowt (Dziewaltowski-Gintowt) Aleksander Kazimierz biskup (PłockMohylów)

$$
\text { sakra } 18 \text { VIII [6 VIII st.st.] } 1872
$$

Illustrissimus, Excellentissimus ac Reverendissimus Dominus, DominusAleksander Casimirus de Dziewałtowo Gintowtt, Dei miseratione et Apostolicae Sedis gratia episcopus Helenopolitanus, suffraganeus dioecesis Plocensis, Ordinum S. Annae et S. Stanislai II $\frac{\text { dae }}{~ c l a s s i s ~ e q u e s, ~ p r a e c o n i s a t u s ~ e s t ~ i n ~ e p i s c o p u m ~ H e l e n o p o l i t a n u m ~ e t ~}$ suffraganeum Plocensem a Summo Pontifice papa nostro Pio IX in consistorio publico Romae septimo Kalendas Martii, die nempe 23. Februarii, 1871 anno habito, consecratus vero Petropoli, in ecclesia parochiali S. Catharinae V.M. sub regimine PP. Ordinis Praedicatorum, intra Missarum solemnia, ab Excellentissimo ac Reverendissimo Domino Antonio Fijałkowski, archiepiscopo Mohiloviensi, metropolitano omnium Ecclesiarum Romano-Catholicarum in universo Imperio Russiaco, Sacrae Theologiae et SS. Canonum doctore pluriumque ordinum equite, assistentibus Illustrissimis ac Reverendissimis Dominis Vincentio Lipski, episcopo Jonopolitano, suffraganeo Tiraspolensi, et Georgio Iwaszkiewicz, episcopo Antedonensi, suffraganeo Mohiloviensi, spectante saeculari ac regulari clero nec non fideli populo ad Divina congregato, die 6. veteris stili mensis Augusti, quae fuit Dominica IX post Pentecosten, in octava beatae Cunegundis Virginis 1872 anno, iuxta vero calendari novi stili die 18. mensis Augusti, quae fuit Dominica XIII post Pentecosten et III Augusti 1872 anno.

Archiwum Diecezjalne w Płocku, sygn. 315/B, karta tytułowa.

Górski Wojciech Józef biskup (Kielce)

sakra $15 \times 1809^{57}$

Beatissime Pater! Adalbertus Gorski, episcopus Kielcensis, post suam praeconisationem in anno 1803, postquam ad gradum episcopi consecratus 15. Octobris 1809 anno et ad suam cathedram installatus extiterit, episcopalis sui officii sequentes explevit functiones. Et quidem a die suae consecrationis uti supra, usque ad ultimam Decembris anni 1811, hoc est in spatio duorum annorum, duorum

${ }^{57}$ Por.: Wypisy źródtowe do biografii polskich biskupów, cz. 10, s. 244-245 nr 44. 
mensium ac quindecem dierum, illo administrante: $1^{\circ}$. Ad sacramentum confirmationis huiusce temporis intervallo accessere personae $52660 \cdot 2^{\circ}$. Ad sacrum presbyteratus ordinem promoti personae $51 \cdot 3^{\circ}$. Ad sacrum diaconatus personae $47 \cdot 4^{\circ}$. Ad sacrum subdiaconatus personae $49 \cdot 5^{\circ}$. Ad minores ordines personae $41 \cdot 6^{\circ}$. Tres abbatissae monialium consecratae, quarum una Ordinis S. Benedicti, binae vero Ordinis S. Norberti $7^{\circ}$. Praeterea novem virgines cum professione votorum ad consecrationem accesserunt $\bullet 8^{\circ}$. Calices consecrati $-15 \bullet 9^{\circ}$. Altaria portatilia consecrata $-10 \cdot 10^{\circ}$. Campanae consecratae $-3 \cdot 11^{\circ}$. Ecclesiae parochiales visi-tatae $-23 \cdot 12^{\circ}$. Monasteria religiosorum visitata -3 . Monasteria monialium visitata -2 . Et siquidem praesentibus temporibus, circumstanciis prorsus adversis, et aditum Sanctae Sedis Apostolicae impedientibus, limina Apostolorum pro officii sui satisfactione, suique devotione in persona sui haud visitare valeat, ad visitanda $\mathrm{S}$ - Apostolorum limina in suum verum ac legitimum plenipotentem, Illustrissimum Joannem Adorni, Datariae Apostolicae officialem et reguum Dresdensem agentem, constituit, eumque obligavit, ut praesentem relationem Sanctitati Vestrae humillime substerneret.

ASPF, Scritture riferite ne Congressi: Moscovia, Polonia e Ruteni, vol. 19, k. 4r (pismo biskupa W.J. Górskiego do papieża Piusa VII z daty: Kielce, 14 III 1812).

Gzowski Franciszek biskup (Wilno)

chrzest $14 \times 1732$

zgon 21 XII 1785

pogrzeb 15 I $1786^{58}$

Ad requisitionem Magnificorum Dominorum Antonii et Antoninae de Żebrowskie Gzowsciorum, nobilium, legitimorum coniugum, inveni in libro baptizatorum supradictorum Magnificorum baptizatum filium nomine Franciscum [...] anno 1732 $\frac{\mathrm{do}}{}$, die. 14. Octobris, levantibus a sacro fonte Magnifico Domino Francisco Przysiecki, dapifero Plocensi, et propria uxore Anna Przysiecka, assistentibus Magnifico Domino Joanne Pożarycki et Magnifica Domina Anna de Sobolewskie Żebrowska, Magnifico Domino Georgio Przysiecki et Magnifica Domina Victoria Żebrowska, et prout in libro inveni metricali parochiae Iwienicensi, ita requirentibus extrado [...]. Dominicus Grzybowski, vicedecanus Minscensis, parochus Iwienicensis.

ASV, Archivio Concistoriale, Processus Consistorialis, vol. 182, k. 409r-v.

1785, December, 21. Dnia dzisiejszego wieczorem, około godziny dziewiątej, zakończył swe doczesne życie Jaśnie Wielmożny Jmć X. Franciszek Borg[iasz] Gzowski, biskup tespieński, sufragan trocki, kanonik katedralny wileński. Mąż

${ }^{58}$ Szostkiewicz, Katalog, s. 451 (mylnie jako Franciszek Ludwik Gazowski); Nitecki, Biskupi, kol. 138 („14 X 1732-21 XII 1785”). Także: K.R. Prokop, «Diario Ordinario» oraz «Notizie», s. 130. 
życia przykładnego, w kościelnych prac posłudze ochotnego, i niespracowany, mający lat około 56. Biskupem był lat kilka. Tego samego roku, którego się do wieczności przeniósł, przed kilku miesiącami uczcił go Najjaśniejszy Pan Król Jegomość Orderem Orła Białego ${ }^{59}$.

1785, December, 22. O ósmej [godzinie] ogłosiły dzwony po całym Wilnie śmierć spomienionego biskupa. Ciało zmarłego złożone [jest] do czasu w sali jegoż rezydencji, gdzie za pozwoleniem J.W. Xięcia Jmci biskupa [wileńskiego] ołtarze porobiono i Msze św. się odprawowały.

1786, Januarius, 15. Niedziela druga po Trzech Królach. [...] O piątej był paradny kondukt śp. JW. JX. Gzowskiego, biskupa tespieńskiego, sufragana trockiego. Ciało jego było złożone w kościele św. Kazimierza w Rynku, gdzie był katafalk przybrany [...]. Prowadził ciało JW. JX. Zienkowicz, biskup, [...] do zamkowej kaplicy św. Kazimierza.

APBKr, S-Wi-5, s. 107 [k. 54r], 110 [k. 55v].

Horain Aleksander Kazimierz biskup (Żmudź)

rezygnacja z sufraganii 17 I 1764
zgon 14 VII $1774^{60}$

Praesenti publico instrumenti cunctis pateat et evidenter notum sit. Anno a Nativitate Domini Nostri Jesu Christi MDCCLXIV, Indictione Romana XII, pontificatus Sanctissimi Domini Nostri Domini Clementis, Divina Providentia papae eius nominis XIII. anno VI, die Lunae XVII mensis Januarii, in mei notarii publici testiumque ad id specialiter rogatorum infrascriptorum praesentia, constitutus personaliter Illustrissimus et Reverendissimus Dominus Alexander Horain, episcopus Hirenensis, suffraganeus et praepositus cathedralis Samogitiensis nec non archidiaconus itidem cathedralis Vilnensis ac referendarius Magni Ducatus Lithuaniae, principalis, sanus mente et corpore existens, palam, sponte, libere ac per expressum recognovit, [...] quod illustrissimus recognoscens sit iam aetatis annorum plusquam sexaginta taliterque ac ob id etiam quia magnas curas circa negotia utriusque capituli cathedralis unius Vilnensis ex vi archidiaconatus, alterius Samogitiensis ex vi praepositurae tum officia episcopalia ratione dicti suffraganeatus sibi incumbentia, ab annis triginta diligentissime gesserat quodammodo viribus confectas existat et hic Vilnae circa ecclesiam cathedralem plerumque re-

\footnotetext{
${ }^{59}$ Por.: Kawalerowie i statuty Orderu Orła Białego 1705-2008, oprac. M. Męclewska, Warszawa 2008, s. 232nn (gdzie pośród wyróżnionych tym odznaczeniem w roku 1785 osób brak wskazania na osobę biskupa F. Gzowskiego, natomiast jest odnotowany sufragan trocki Jerzy Antoni Połubiński - s. $234 \mathrm{nr} 729$ ).

${ }^{60}$ Szostkiewicz, Katalog, s. 467-468 (brak informacji o rezygnacji z sufraganii); Nitecki, Biskupi, kol. 458 (24 VII 1774) oraz s. 41 („,[sufragan] 1731-1774”); Jakubowski, Solarczyk, Organizacja Kościoła rzymsko-katolickiego na ziemiach polskich, s. 233 (,[sufragan] 1731-1774”). Nadto: Urzędnicy centralni i dygnitarze Wielkiego Księstwa Litewskiego XIV-XVIII wieku. Spisy, oprac. H. Lulewicz, A. Rachuba, Kórnik 1994, s. 172 (nr 1357), 210.
} 
sideat, propter suam adversam valetudinem ac incommoda ac distantiam variarum ad milliaria Lithvanica circiter quadraginta hinc ab ecclesia cathedrali Vilnensi ad Samogitiensem pro officis et functionibus episcopalibus eo magis cum stante nunc interregno in patria ex munere referendariatus sui Magni Ducatus Lithuaniae saepius ad comitia et concilia Regni ipsum evocari est necesse facile condescendere non valet, favore Perillustris Admodum Reverendi Michaelis Chominski, custodis cathedralis Samogitiensis si et in quantum a quo de iure nominabitur resignandi sive dimittendi, ita tamen, ut sibi illustrissimo recognoscenti pensio annua ad vitae tempora [...] authoritate Sanctae Sedis apostolica decernatur et reservatur [...]. Acta haec sunt Vilnae [...], praesentibus Admodum Reverendo Josepho Gradowski, praeposito hospitalis Vilnensis S. Rochi, ac Generoso Antonio Skawronski, testibus ad praemissa rogatis et requisitis.

ASV, Archivio Concistoriale, Processus Datariae 142, b.p. (rok 1765).

1774, Julius, 14. Illustrissimus Alexander Horain, episcopus Hirensis, archidiaconus Vilnensis, aeques S. Ruberti [sic!], referendarius Magni Ducatus Lithuaniae ac confrater Ordinis nostri [tj. franciszkanów obserwantów] (Romae in Ara Caeli e manibus reverendissimi generalis ministri habitum Tertii Ordinis suscepit tempore Magni Jubilaei anno 1750), plenus dierum et meritorum, quemadmodum pie vixit, sic sancte in Domino obiit tempore vesperarum in Capella S. Casimiri ecclesiae cathedralis.

APBKr, S-Wi-4, s. 268.

Hozjusz Stanisław Józef biskup (Przemyśl - Inflanty - Kamieniec - Poznań), komendatoryjny opat (Czerwińsk)

zgon $13 X[1738]^{61}$

Die 13 $3^{\text {ta }}$ Octobris. [Obitus] Illustrissimi ac Reverendissimi Domini Stanislai Josephi Hosii, episcopi Posnaniensis, abbatis commendatarii Cervenensis, sub cuius regimine intercesserunt accordata abbatiae nostrae perpetuo a serenissimis regibus Poloniae praesentandae.

BKSC, Liber mortuorum [abbatiae] Czervenensis, s. 341.

${ }^{61}$ Szostkiewicz, Katalog, s. 469; Nitecki, Biskupi, kol. 154 (13 X 1738). Nadto: Folwarski, Poczet opatów klasztoru kanoników regularnych w Czerwińsku, s. 47 (,zmarł prawdopodobnie 13 X 1737 r.” [sic!]); B. Przybyszewski, Katalog kanoników krakowskiej kapituły katedralnej w XVIII wieku, Kraków 2009, s. 63. 
Ego Georgius ab Ecklis Hülsen, modernus episcopus Smolenscensis, ex certis causis et iam Summo Pontifici notis, licet super regimine dictae Ecclesiae Smolenscensis coadiutor perpetuus cum futura successione apostolica authoritate mihi deputatus fuerit, nihilominus dictam Ecclesiam Smolenscensem libere dimitto in manibus dicti Summi Pontificis, ad quem effectum constituo et deputo in meum procuratorem specialem Admodum Reverendum Dominum Tissot, procuratorem Congregationis Missionis [...], etiam cum facultate substituendi unum vel plures procuratores cum facultate dicto meo procuratori vel ab eo substituendo praebendi $[\ldots]$. In quorum fidem hoc praesens procurae mandatum atque dimissionem mea manu subscripsi sigilloque meo munivi. Actum Dagdae, 22. Octobris 1762 .

ASV, Archivio Concistoriale, Processus Datariae 140, b.p. (rok 1763).

Jezierski Stanisław Rajmund biskup (Baków)

zgon $29 I V 1782^{63}$

De obitu seniculi coadiuti mei, Illustrissimi scilicet Stanislai Jezierski, episcopi Baccoviensis, per Eminentiam Vestram Sanctae Sedi deferre [...]. Mortuus est praememoratus mei coadiutus die 29. Aprilis [1782] annorum vitae suae 96, episcopatus vero 44, bona verba solum mihi relinquens, meo Providentiae Divinae committens.

ASPF, Scritture riferite ne Congressi: Moscovia, Polonia e Ruteni, vol. 15, k. 137r (list biskupa bakowskiego Dominika Piotra Karwosieckiego do kardynała-prefekta Kongregacji De Propaganda Fide Carlo Rezzonico z daty: Lwów, 2 VI 1782).

\section{Kiełczewski Dominik Józef biskup (Chetm/Krasnystaw)} rezygnacja $z$ sufraganii 27 III $1775^{64}$

${ }^{62}$ T. Długosz, Dzieje diecezji smoleńskiej, Lwów 1937, s. 78 nr 15 (,zmarł 1762 r.” [sic!]); Szostkiewicz, Katalog, s. 469 („15 VII 1763 zrzekł się biskupstwa i zamieszkał w Warszawie”); Nitecki, Biskupi, kol. 156 („29 I 1763 zrezygnował z urzędu”); Jakubowski, Solarczyk, Organizacja Kościoła rzymsko-katolickiego na ziemiach polskich, s. 185 (,„[ordynariusz] 1745-1763; zrezygnował z urzędu"). Nadto: Z. Iwicki, Nekropolia oliwska, s. 127-130.

${ }^{63}$ Szostkiewicz, Katalog, s. 481-482; Nitecki, Biskupi, kol. 183.

${ }^{64}$ Szostkiewicz, Katalog, s. 484 (brak informacji o rezygnacji z sufraganii); Nitecki, Biskupi, kol. 201 (,z sufraganii chełmskiej zrezygnował w 1775 r.”); Przybyszewski, Katalog kanoników krakowskiej kapituly katedralnej, s. 71-72 (,w 1775 r. zrezygnował z sufraganii chełmskiej, o którą zbytnio nie dbał"); Jakubowski, Solarczyk, Organizacja Kościoła rzymsko-katolickiego na ziemiach polskich, s. 57 (,,[sufragan] 1760-1775”). 
Anno Domini 1775, die Lunae, 27. mensis Martii, Cracoviae. Coram officio actisque praesentis curiae Celsissimi principis Illustrissimi et Reverendissimi Domini Caietani Ignatii Sołtyk, episcopi Cracoviensis, ducis Severiae, constitutus personaliter Illustrissimus et Reverendissimus Dominus Dominicus Kielczewski, episcopus Hermpolitanus, suffraganeus dioecesis Chelmensis, ecclesiae cathedralis Cracoviensis canonicus, principalis, palam, sponte et libere verbisque dissertis ac per expressum recognovit, quia ipse facta secum matura deliberatione, quod ob provectam aetatem suam dioecesis Chelmensis ad obeundas functiones episcopales adire in eaque morari nequeat, uti fixo a longo tempore Cracoviae circa ecclesiam cathedralem domicilio, tum ex aliis rationibus animum suum permoventibus, habendo ex Providentia Divina reditus tam ex bonis haereditariis, quam ex beneficiis ad sustinendam decentiam episcopalem sufficientes, suffraganeatui Chelmensi renuntiandum esse censuit, uti quidem sub beneplacito Sanctissimi Domini Nostri, ac sub benignissima eius exercendorum pontificalium de consensu respectivorum loci ordinariorum facultate, renuntiat, resignat ac se a dicto suffraganeatu Chelmensi liberandum et exvinculandum postulat hac sua recognitione ad praemissa mediante, quam in meliorem fidem manu sua subscripsit.

ASV, Archivio Concistoriale, Processus Datariae 152, s. 212 (14 VII 1775: Copia dimissionis).

Kossakowski Jan Nepomucen biskup (Inflanty/Wenden - Wilno)

sakra [2 II 1794$]^{65}$

Scio [Joannem Nepomucenum Kossakowski] consecratum fuisse in episcopum Grodnae a defuncto episcopo Vilnensi, principe Massalski, cum assistentia aliorum duorum episcoporum, videlicet praedecessoris eius Josephi Kossakowski et episcopi Prussensis in partibus Michaelis Sierakowski, idque testari ex eo quod audivi a decano Olycensi id saepius, qui praesens dictae consecrationi fuit. [...] Scio ipsum fuisse consecratum ab annis circiter quinque. Nominatus enim fuit episcopum in ultimis comitiis Grodnensibus, quae fuerunt 1793 et paulo post, ante mensem Septembris, consecratus in episcopum coadiutorem Livoniae.

ASPF, Scritture riferite ne Congressi: Moscovia, Polonia e Ruteni, vol. 17, k. 443r-v (zeznanie świadka Jakuba Dederko, prepozyta ołyckiego, w procesie informacyjnym J.N. Kossakowskiego z roku 1798, przy translacji z biskupstwa inflanckiego na wileńskiej [Sankt Petersburg, 21 VII/1 VIII 1798]).

${ }^{65}$ Szostkiewicz, Katalog, s. 490; L. Żytkiewicz, Kossakowski Jan Nepomucen herbu Ślepowron, przydomek Korwin (1755-1808), biskup inflancki i wileński, w: Polski słownik biograficzny, t. 14, Wrocław-Warszawa-Kraków 1968-1969, s. 266 („dnia 2 II 1794 r. konsekrowany w Wilnie”); Nitecki, Biskupi, kol. 217 (brak daty sakry). 
Krasiński Ignacy arcybiskup (Warmia - Gniezno)

Beatissime Pater! Liceat capitulo metropolitano Gnesnensi inter oscula pedum Sanctitatis Vestrae humillima precum expositione notum facere. Post obitum Celsissimi principis archiepiscopi Gnesnensis Ignatii Krasicki, die $14^{\text {ta }}$ mensis Martii anno 1801 subsecutam, vacanti sedi Gnesnensi ad literas nominationis serenissimae regiae maiestatis Friderici Wilhelmi, domini nostri clementissimi, in archiepiscopum Ecclesiae nostrae Illustrissimum et Reverendissimum Ignatium comitem Raczynski, Ecclesiae Posnaniensis episcopum, virum generis nobilitate, studio, meritis in Ecclesiam suam percelebrem, pro consuetudine capituli nostri, concordi animarum sensu, a nobis electum esse. Quare supplices sumus Sanctitati Vestrae, ut electionem hanc pro suprema Apostolicae Sedis authoritate ratam esse velit, eamque supremo suo in terris oraculo Sanctitas Vestra confirmet.

ASPF, Scritture riferite ne Congressi: Moscovia, Polonia e Ruteni, vol. 18, k. 414r-v (pismo gnieźnieńskiej kapituły metropolitalnej do papieża Piusa VII z daty: Gniezno, 14 III 1805 [odpis]).

Krosnowski Mikołaj arcybiskup (Inflanty - Lwów), komendatoryjny opat (Czerwińsk)

zgon 27 IX [1653 $]^{67}$

Die $27^{\text {ma }}$ Septembris. [Obitus] Illustrissimi et Reverendissimi Domini Nicolai Krosnowski, archiepiscopi Leopoliensis, abbatis canoniae nostrae [Czervenensis], optime meriti de hac canonia, multa enim beneficia praestitit, pro cuius anima ex fundatione quotannis anniversarium celebrare tenemur.

BKSC, Liber mortuorum [abbatiae] Czervenensis, s. 325.

Lascaris (Laskary) Jerzy Maria biskup ([Łuck]), patriarcha (Aleksandria - Jerozolima)

narodziny 16 II 1706

chrzest 8 III 1706

prezbiterat 30 I 1729

zgon 11/12 XII 1795

${ }^{66}$ Szostkiewicz, Katalog, s. 492; Nitecki, Biskupi, kol. 224; M. Kosman, Poczet arcybiskupów gnieźnieńskich i prymasów Polski, Kraków 2012, s. 319.

${ }^{67}$ Szostkiewicz, Katalog, s. 494; Nitecki, Biskupi, kol. 229 (26 IX 1653). Także: Gawarecki, Wiadomości o starożytnym klasztorze, s. 202; J. Fijałek, Kościót rzymsko-katolicki w Inflantach pod władztwem polskim (1582-1772/95), „Kwartalnik Teologiczny Wileński”, 1 (1923) z. 2, s. 186; Folwarski, Poczet opatów klasztoru kanoników regularnych w Czerwińsku, s. 34-35. 
Die 8. Martii 1706, Georgius, filius Nobilis Domini co[mitis] Theodori Lascaris et Nobilis Dominae co[mitissae] Geltrudis [sic!], eius uxoris, natus die 16. Februarii quotquot elapsi, hora circa 12a , fuit privatim in ecclesia parochiali Ss. Quirici et Julitae a ma[gistro?] Joanne Baptista Piccoloto, archipresbitero dictae ecclesiae, lavacro baptismatis ablutus. Levavit de sacro fonte Domina Rosana, uxor Domini Joannis Baptistae de Rubeis, de parochia S. Stephani. Delatus postea ad dictam ecclesiam parochialem die 19. Maii eiusdem anni, fuit sacris solemnibus caeremoniis a me suprascripto roboratus iuxta formam Ritualis Romani. Patrinus in cathechismo fuit Illustrissimus et Excellentissimus Dominus Joannes Delfinus, patritius Venetus, ad Caesarem pro Venetia deputatus orator [...]. Assistentes pariter in cathechismo fuerunt Illustrissimus Dominus co[mes] Bonnelius Moscardus pro Illustrissimo et Excellentissimo Domino generali Joanne Aloysio Magnanino [...], et Perillustris Dominus Michael Vitanovich pro Illustrissima Domina Maria Michaele, armorum gubernatore[?]. Franciscus Philippi, archipresbiter. Veronae, d. 16. Decembris 1722.

ASV, Archivio Concistoriale, Processus Datariae, vol. 118, k. 89r.

Prosper tituli S. Silvestri in Capite Sanctae Romanae Ecclesiae presbyter cardinalis Marefuscus, Sanctissimi Domini Nostri Papae vicarius generalis Romanaeque Curiae eiusque districtus iudex ordinarius etc., universis et singulis [...] attestamur, Illustrissimum et Reverendissimum P.D. Nuntium Baccari, episcopum Brianensem, suffraganeum nostrum, Romae, die Dominico 30. Januarii 1729, in capellae suae solitae habitationis, ordinationem particularem celebrante, inter alios dilectum nobis in Christo filium Dominum Georgium Mariam Lascaris, Clericorum Regularium Theatinorum, cum praesentatione sui superioris [...] et cum dispensatione apostolica super defectu aetatis 13 mensium, [...] ad sacrum presbyteratus ordinem, praeviis exercitiis spiritualibus, rite et recte [...] in Domino promovisse et ordinasse. [...] Datum Romae, ex aedibus nostris hac die 11. mensis Februaris anno 1729.

ASV, Archivio Concistoriale, Processus Datariae, vol. 118, k. 90r.

Monsignor Giorgio Lascaris, teatino, patriarca di Gerusalemme, uno de' vescovi assistenti dalla Basilica Vaticana etc., che da qualche tempo non sortiva per gli suoi incomodi, sorpreso da convulsione, circa le ore 7. di Venerdì venendo il

${ }^{68}$ D. Rezza, M. Stocchi, Il Capitolo di San Pietro in Vaticano dalle origini al XX secolo, t. 1 La storia e le persone, Città del Vaticano 2008, s. 238. Zob. także: K.R. Prokop, Wiadomości do biografii biskupów oraz opatów i ksień z ziem Rzeczypospolitej Obojga Narodów z osiemnastowiecznej prasy warszawskiej doby saskiej i stanisławowskiej (1729-1795), „Archiwa, Biblioteki i Muzea Kościelne”, 86 (2006) s. 307; Wypisy źródłowe do biografii polskich biskupów i opatów, cz. 10, wyd. K.R. Prokop, „Archiwa, Biblioteki i Muzea Kościelne”, 97 (2012) s. 260-261 nr 72. 
Sabato 12. del corrente Dicembre, passò all'altra vita nella sua avanzata età di anni 89, mesi 9 e 28 giorni. Il suo corpo, vestito dagli abiti prelatizi, la mattina della seguente Domenica fu esposto sopra un letto alquanto elevato in una camera del suo appartamento, dove erano stati eretii due altari, nel quali egualmente che a quello della sua cappella segreta furono celebrate numerose Messe in suffragio della sua anima. La sera poi di detta Domenica (conforme il privilegio de' patriarchi) fu posto in una carozza da treno, dove prese luogo il reverendo paroco di S. Lucia alle Botteghe Oscura, sua parrocchia, ed un padre teatino, col chiero con la corce, e preceduto da 12 torcie portate dalla propria servitù in livrea di gala, fu trasportato alla chiesa di S. Silvestro a Monte Cavallo dei padri della sua religione, che già era stata apparata a lutto, dove la mattina del seguente Lunedì fu esposto in letto vestito degli abiti sagri Missali con mitra in testa, e cappello prelatizio appeso alla coltre, con attorno 60 ceri e 4 torcie accese, ed ai lati le quattro grandi banderole, che venivano lentamente agitate da altrettanti de' suoi palafrenieri in abito di tutto dublo. In tutta la mattina furono celebrate continuate Messe, e ad ora propria Monsignor Buschi, arcivescovo di Efeso, pontificò la solenne Messa di requie servito da ministri sagri della Cappella Pontificia, ed accompagnato da cantori della medesima. Nelle banche ivi preparate assisterono in abito prelatizio i monsignori vescovi assistenti al Soglio Pontificio, suoi colleghi, i quali assisterono ancora alle solite esequie, ed il tutto terminato, il corpo del defonto prelato fu racchiuso dentro le casse, ed umato in luogo a parte nella cappella del cimiterio di quella chiesa, come egli aveva disposito. In seguito sarà sepolto nella cappella di S. Gaetano, con una lapide sepolcrale.

„Diario Ordinario” R. 1795 nr 2188 (z 19 XII 1795), s. 14-16.

\section{Łubieniecki (Lubieniecki) Mikołaj Jan Damascen biskup (Baków)}

chrzest $7 \times 1652^{69}$

Anno Domini millesimo sexcentesimo quinquagesimo secundo, mense Octobri, die septima, baptizavit Reverendus Dominus Joannes Przybyszevius, praepositus Przybyszeviensis, filium nomine Nicolaum, ex nobilibus parentibus Thoma Troiano Łubieniecki et [brak imienia] Wysocanka, coniugibus legitimis, [natum]. Patrini eius fuerunt Magnificus Dominus Stanislaus Rykulski et Generosa Domina Constantia Podkańska, coniux Magnifici Domini Andreae Rykulski, notarii Cernensis.

ASV, Archivio Concistoriale, Processus Consistorialis, vol. 101, k. 30v (Ex libris metrices ecclesiae parochialis Przybyszeviensis).

${ }^{69}$ Szostkiewicz, Katalog, s. 504; Nitecki, Biskupi, kol. 255 („ok. 1651-1714”). 
Nersesowicz Deodat (Bogdan) biskup (Lwów)

Esposi a Vostra Signoria Illustrissima e Reverendissima con la passata [lettera] la morte di Monsignor Deodato Nersessowicz, vescovo Traianopolitano e coadiutore Armeno, seguita agli 8. corrente [8 V 1709], un'hora dopo meza notte. Confermo l'istesso per assicurare la posta troppo incerta in questi tempi di guerra.

ASPF, Scritture riferite ne Congressi: Moscovia, Polonia e Ruteni, vol. 3, k. 282r (pismo teatyna Stefano Trombettiego do Kongregacji De Propaganda Fide z daty: Lwów, 22 V 1709).

\section{Odyniec (Brzozowiecki-Odyniec) Cyprian Stefan biskup (Mohylów [Połock]) chrzest 5 XI $1750^{71}$}

Ego Joannes Wysocki, parochus Pochostensis, anno Domini 1750, ipso die 5. Novembris, baptizavi infantem Cyprianum Stephanum, filium patris Stanislai Odyniec, dapiferi districtus Braslaviensis, et consortis Antoninae de domo Zebrowsciorum, coniugum legitimorum et nobilium. Patrini fuerunt: Perillustris Magnificus Dominus Franciscus Biesicki, ensifer palatinatus Minscensis, cum Magnifica Domina Constantia Konoplanska, subcameraria districtus Braslaviensis.

ASPF, Scritture riferite nei Congressi. Moscovia - Polonia - Ruteni, vol. 17, k. 529v (Ex libro baptizatorum parochiae Pochostensis/Pohostensis) oraz k. 547r-v (oryginał). Tamże, k. 524r („Dominus Ciprianus Stephanus Brzozowiecki Odyniec, praelatus praepositus archiepiscopalis Ecclesiae Mohiloviensis").

Ogiński Ludwik Karol biskup (Smoleńsk)

zgon 5 VIII $1719^{72}$

${ }^{70}$ Z. Abrahamowicz, Nersesowicz (Niersesowicz) Deodat (ok. 1644-1709), dostojnik Kościoła ormiańsko-unickiego, leksykograf ormiański, kaznodzieja i pisarz ormiańsko-polski, w: Polski słownik biograficzny, t. 22, Wrocław-Warszawa-Kraków-Gdańsk 1977, s. 677 („zmarł 9 V 1709 r.”); Obertyński, Katalog unickich arcybiskupów ormiańskich w Polsce, s. 312 nr 4 („Bogdan (Deodat) Nersesowicz [...] zmarł przed 15 VII 1709”); Petrowicz, La Chiesa Armena in Polonia e nei paesi limitrofi, t. 3, wg indeksu (zwł. s. 57). Nadto: Jakubowski, Solarczyk, Organizacja Kościoła rzymsko-katolickiego na ziemiach polskich, s. 269.

${ }^{71}$ Nitecki, Biskupi, kol. 317 („,? - przed 16 III 1818”). Zob. nadto: Wypisy źródłowe do biografii polskich biskupów, cz. 10, s. $280 \mathrm{nr} 107$.

${ }^{72}$ T. Żychliński, Złota księga szlachty polskiej, t. 5, Poznań 1883, s. 184; Szostkiewicz, Katalog, s. 524 („22 XI 1717 otrzymał prowizję papieską, zmarł zaś w następnym roku”); Nitecki, Biskupi, kol. 317 (,zm. 1718”); Jakubowski, Solarczyk, Organizacja Kościoła rzymsko-katolickiego na ziemiach polskich, s. 185 (,[ordynariusz] 1717-1718; zmarł wkrótce po nominacji”). 
A.D. MDCCXIX. [...] X. Ludwik Oginski, biskup smoleński, umarł w Auguście.

BN, BOZ 941, s. 12. Por.: Pamiętniki Krzysztofa Zawiszy, wojewody mińskiego, (1666-1721), wyd. J. Bartoszewicz, Warszawa 1862, s. 172: „[Roku 1719] Jmć Xiądz Ludwik Ogiński, biskup smoleński, w leciech 39 niespodziewanie umarł w domu Jmć Pana Trzebińskiego, dnia 5 sierpnia, na nieuleczalną zapadłszy chorobę, którą zowią miserere”.

Olszowski Andrzej arcybiskup (Gniezno)

zgon 29 VIII $1677^{73}$

Dominus archiepiscopus Gnesnensis [Andreas Olszowski] die 29. Augusti 1677, Gedani, horis pomeridianis, morte improvisa obiit.

ASR, Paesi stranieri (sec. XVII-XVIII), Busta 12, fasc. 14, s. 394.

Ostaszewski Tomasz biskup (Płock)

zgon 17 I $1817^{74}$

Illustrissimus, Reverendissimus Dominus Prażmowski, praepositus ecclesiae cathedralis Plocensis, literis suis die 18 ${ }^{\mathrm{a}}$ mensis et anni currentis Varsaviae datis notificavit suum capitulum de subsecuta morte Excellentissimi ac Reverendissimi Domini Thomae Ostaszewski, episcopi Plocensis, die 17르 mensis et anni currentis Varsaviae.

Archiwum Diecezjalne w Płocku, ACapPloc 30, k. 26v (Fata Illustrissimi, Excellentissimi ac Reverendissimi Thomae Ostaszewski, episcopi Plocensis); zob. ponadto: BKSC, Liber mortuorum [abbatiae] Czervenensis, s. 313: „Die 15 $5^{\text {ta }}$ Septembris. [Obitus] Illustris Admodum Reverendi Ignatii Blasii Augustini Ostaszewski, Canonicorum Regularium Lateranensium, fratris ad praesens ep[isco]pi nominati Plocensis, multorum meritorum ac in communitate sua obsequiorum viri, qui post resignationem beneficii Brochoviensis officium custodis Cervenensis annis 6 agens, adeptusque plebaniam Borzęcinensem ante menses duos, in cuius cura aegritudine detentus, Sochaczevam curationis cura divertens, ibidem post protractos dies duos occubuit sepultusque anno 1815 , aetatis suae 53 , a professione canonica 27 ”.

\section{Radoszewski Wojciech Józef biskup (Kraków [Sandomierz])}

chrzest 5 IV $1721^{75}$

${ }^{73}$ Szostkiewicz, Katalog, s. 526; Nitecki, Biskupi, kol. 321; Kosman, Poczet arcybiskupów gnieźnieńskich, s. 256.

${ }^{74}$ Nowowiejski, Plock. Monografia historyczna, s. 72-73 nr LXXIII (,umarł w Warszawie w styczniu 1817 r.”); Szostkiewicz, Katalog, s. 526; Nitecki, Biskupi, kol. 325 (17 I 1817).

${ }^{75}$ J. Wiśniewski, Katalog prałatów i kanoników sandomierskich od 1186-1926 r. tudzież sesje kapituly sandomierskiej od 1581 do 1866 r., Radom 1926, s. 243 („urodził się w 1721 r.”); B.S. Kumor, Dzieje diecezji krakowskiej do roku 1795, t. 2, Kraków 1999, s. 112 (,urodził się w 
Anno Domini millesimo septingentesimo vigesimo primo, die vero quinta Aprilis, Perillustris Admodum Reverendus Adalbertus Dobrakowski, canonicus Pilecensis, curatus in Michałow, baptizavit Adalbertum, Generosi ac Nobilis Laurentii Boxa et Mariannae Dmuchowska, coniugum legitimorum, cuius patrini fuere Reverendus Balthasar Sołtyskiewicz, commendarius Michałowiensis, et Generosa ac Nobilis Domina Constania Malinowska de Zagaiow.

ASV, Archivio Concistoriale, Processus Consistorialis, vol. 188, k. 197v-198r.

\section{Rudnicki Sylwester biskup (Łuck)}

zgon 7 V $1777^{76}$

La morte di Monsignor Silvestro Rudnicki, vescovo Ruteno di Luceoria, accaduta li 7. del corrente, ha portata la discordia, tanto nel seno dell'Ordine Basiliano, quanto tra questo ed il clero Ruteno. E quello rimasto malcontento della nomina data da Sua Maestà al Padre Cipriano Stecki, di famiglia molto nobile dalla Gran Polonia, ma professo della Provincia di Lituania, ed attualmente procuratore di uno di quei monasterii, come contrario alle loro regole, confermate dalla Santa Sede e dalla Reppublica, colle quali si stabilisce che i monaci di Lituania abbiano tutti i benefizi della Lituania, e rispettivamente i Poloni quelli della Polonia.

ASPF, Scritture riferite nei Congressi: Moscovia, Polonia e Ruteni, vol. 13, k. 84r (pismo nuncjusza apostolskiego w Rzeczypospolitej Obojga Narodów Giovanniego A. Archettiego, arcybiskupa tytularnego Chalcedonu, do kardynała-prefekta Kongregacji De Propaganda Fide, $\mathrm{z}$ daty: Varsavia, $21 \mathrm{~V} 1777$ [odpis]).

Sapieha Józef Julian biskup (Wilno)

zgon 4 XII $1754^{77}$

Die 4. Decembris 1754. A prandiis post horam $3 \frac{\text { tiam }}{21 l u s t r i s s i m u s, ~ R e v e r e n d i s s i m u s ~}$ Dominus Josephus Sapieha, coadiutor episcopi Vilnensis, apoplexia tactus, cum summo universorum dolore desiit vivere.

CVIA, F 1135 ap. 20, k. 44v. Zob. również: AGAD, Dział VI, II-80a, s. 1989 (zapiska Michała Kazimierz Radziwiłła pod datą 21 XII 1754 r.: „Z Wilna odebrałem wiadomość, że xiądz Józef Sapieha, biskup diocesareński, sufragan i koadiutor wileński, referendarz litewski, die 4. praesentis $\mathrm{w}$ Wilnie desiit vivere, cuius anima sit in benedictione, mało chorując, inopinate umarl").

Michałowie koło Pińczowa, jako syn Wawrzyńca i Marianny Duchowskiej; ochrzczony został 5 IV 1721 r.”); Nitecki, Biskupi, kol. 373 („,ur. 1721”). Także: Prokop, «Diario Ordinario» oraz «Notizie», s. 138.

${ }^{76}$ Por:: D. Blazejowskyj, Hierarchy of the Kyivan Church (861-1990), Romae 1990, s. 264; tenże, Іерархія Київської Церкви (861-1996), Львів 1996, s. 264. Nadto: Jakubowski, Solarczyk, Organizacja Kościoła rzymsko-katolickiego na ziemiach polskich, s. 261.

${ }^{77}$ Szostkiewicz, Katalog, s. 551; Nitecki, Biskupi, kol. 393. 
Skirmunt (Skirmont) Joachim biskup (Zmudź/Miedniki)

sakra 9 IV $1702^{78}$

9 na [Aprilis 1702], in quam incidebat Dominica Palmarum, consecravi [odnosi się do ordynariusza warmińskiego Andrzeja Chryzostoma Załuskiego] Joachimum Skirmont, suffraganeum Samogitiae, in assistentia episcopi Samogitiae [mowa o Janie Kryszpinie-Kirszensteinie] et suffraganei Varmiensis [mowa o Kazimierzu Benedykcie Leżeńskim] in collegiata Guttstadiensi.

Andreae Chrysostomi in Załuskie Załuski [...] epistolarum historio-familiarium tomus tertius [1701-1711], Brunsbergae 1711, s. 191 (Consecratio Joachimi Skirmont).

Sosnowski Leon Konstantyn biskup (Inflanty)

rezygnacja z sufraganii 13 VII $1779^{79}$

Excellentissimo, Illustrissimo ac Reverendissimo Domino, Domino Joanni Andrea comiti Archetti, Dei et Apostolicae Sedis gratia archiepiscopo Chalcedonensi, nuntio apostolico [...] per Poloniam, humillima obsequia. Excellentissime ac Reverendissime Domine, Domine Patrone Colendissime. Cum ob varia impedimenta a multis iam annis diaecesim Livoniensem muneris mei gerendi causa adire nequiverim, et conscientia graveo, quod in magna Messe[sic!] illustrissimum episcopum Albae Russiae, cui illas nunc subest exercitio pontificalium non adiuvem, constitui, igiter apud me suffraganeatum Livoniensem, in quem ex gratia Sanctissimi Domini Nostri piae memoriae Papae Clementis huius nominis XIII. possideo, resignare, prout per praesentes in manus Excellentiae Vestrae Illustrissimae ac Reverendissimae, uti legati a latere, resigno, humiliter rogans quatenus Excellentia Vestra hanc dignitatem conferendam dignetur a Sanctissimo Domino Nostro exorare pro eo, quem promovet Illustrissimus Reverendissimus Stanislaus [Siestrzeńcewicz], episcopus Albae Russiae, pro iure suo, quod ei competit ad id ex vi fundationis, uti illius dioeceseos ordinariam iurisdictionem exercenti, si ita Sanctissimo Domino Nostro visum fuerit. [...] Datum Szebrini, anno millesimo septingentesimo septuagesimo nono, mense Julio, die decima tertia. Constantinus Sosnowski, episcopus Arethusensis, praepositus cathedralis Luceoriensis, manu propria.

ASV, Archivio Concistoriale, Processus Datariae 157, k. 69r-v (16 VI 1780).

${ }^{78}$ Szostkiewicz, Katalog, s. 555 („prowizję otrzymał 8 VIII 1701, wkrótce umarł”); Nitecki, Biskupi, kol. 405 (,zmarł 1701 przed otrzymaniem bulli nominacyjnej”); Jakubowski, Solarczyk, Organizacja Kościoła rzymsko-katolickiego na ziemiach polskich, s. 233 (tamże przyp. 1243: „Zmarł przed otrzymaniem bulli nominacyjnej”). Por.: Wołonczewski, Biskupstwo żmujdzkie, s. 94.

${ }^{79}$ Szostkiewicz, Katalog, s. 557 (brak informacji o rezygnacji z sufraganii); Nitecki, Biskupi, kol. 412 („16 VI 1780 r. zrezygnował z funkcji sufragana”); Jakubowski, Solarczyk, Organizacja Kościoła rzymsko-katolickiego na ziemiach polskich, s. 79 (,[sufragan] 1767-1780”). 
Starczewski Stanisław biskup (Płock), administrator opactwa (Czerwińsk) zgon 15 IX [1643] $]^{80}$

Die 15 ${ }^{\text {ta }}$ Septembris. [Obitus] Illustrissimi ac Reverendissimi [Domini] Stanislai Starczewski, episcopi Lacedemoniensis, abbatis canoniae nostris [Cervenensis].

BKSC, Liber mortuorum [abbatiae] Czervenensis, s. 313.

Święcicki Mikołaj Stanisław biskup (Kijów - Poznań)

sakra 14 IV $1697^{81}$

Varsavia, 14. Aprilis 1697. Hodie consecratus fuit in episcopum Kiioviensem Nicolaus Swięcicki a cardinale primate [mowa o Michale Stefanie Radziejowskim], ego quoque [odnosi się do ordynariusza płockiego Andrzeja Chryzostoma Zatuskiego] cum episcopo Posnaniensi [mowa o Stanistawie Janie Witwickim] assistebam.

Andreae Chrysostomi in Załuskie Załuski [...] epistolarum historio-familiarium tomus secundus [1696-1700], Brunsbergae 1711, s. 315.

Święcicki Stanisław Jacek biskup (Żmudź - Chetm/Krasnystaw)

zgon $26 \times 1696^{82}$

Die 26 $6^{\text {ta }}$ Octobris. [Obitus] Illustrissimi ac Reverendissimi [Domini] Stanislai Hiacinthi Swiecicki, episcopi Chełmensis, nominati Culmensis, praepositi ad Sanctum Georgium Varsaviensis, quondam huius canoniae [Czervenensis] professi, confratris nostri, sub cuius prioratu miraculis imago Beatissimae denuo inclaruit. Obiit Chełmae anno Domini $1696^{\text {to }}$.

BKSC, Liber mortuorum [abbatiae] Czervenensis, s. 354.

${ }^{80}$ Szostkiewicz, Katalog, s. 559; Nitecki, Biskupi, kol. 416 (wyłącznie data roczna 1643). Także: Nowowiejski, Płock. Monografia historyczna, s. 79 (nr 12); Folwarski, Poczet opatów klasztoru kanoników regularnych w Czerwińsku, s. 30, 32; T. Żebrowski, Zarys dziejów diecezji płockiej, Płock 1976, s. 6 (nr 14).

${ }^{81}$ Ch.G. Friese, De episcopatu Kioviensi, cuius sedes olim fuit Kioviae, nunc vero Zytomiriae in Ukraina, eiusque praesulibus brevis commentatio [...], Varsaviae 1763, s. 93 („Nicolaus Swiencicius [...] 14. Aprilis 1697 [omytkowo jest 1797], a fautore suo Radzieiovio, Regni primate, Vitvicio Posnaniensi et Zaluscio Plocensi episcopis assistentibus, fuit consecratus"); Wypisy źródtowe do biografii polskich biskupów, cz. 11, s. 354 nr 78. Nadto: Archiwum trzemeszeńskie, s. 65, 67-68; Szostkiewicz, Katalog, s. 567; Nowacki, Dzieje archidiecezji poznańskiej, t. 2, s. 109; Dola (I), s. 271 nr 30; Nitecki, Biskupi, kol. 440; Makarczyk, Procesy informacyjne, s. 245-246; taż, Polscy biskupi z Zakonu Kanoników Regularnych Laterańskich, s. 44-47.

${ }^{82}$ Szostkiewicz, Katalog, s. 567; Nitecki, Biskupi, kol. 440 (X 1696). Nadto: Makarczyk, Procesy informacyjne, s. 242-245; taż, Polscy biskupi z Zakonu Kanoników Regularnych Laterańskich, s. 39-44. 
Tyszkiewicz Antoni Domini biskup (Kijów - Żmudź)

zgon 30 I $1762^{83}$

1762, Februarius, 12. Hac die publicam notitiam accepimus de obitu Illustrissimi, Excellentissimi Antonii Dominici Tyszkiewicz, comitis in Łohoysk et Berdyczow, episcopi Samogitiensis, nec non ante ipsum obitum nominati Vilnensis [...], qui 30. Januarii [1762] vivere desiit Olsiadis in Samogitia.

APBKr, S-Wi-4, s. 31. Zob. nadto: LMAB, F 9 - 162-166, k. 52r (12 X 1739): „Po wczorajszej [11 X 1739] tak uroczystej konsekracji w katedrze [wileńskiej] na biskupstwo menniteńskie za ordynacją Klemensa XII, papieża, przez JJ. WW. biskupów: Zienkowicza, wileńskiego, jegoż koadiutora Sapiehę, diocezarieńskiego, i Horaina, hireneńskiego, kanonika wileńskiego Antoniego Tyszkiewicza na sufragana kijowskiego wobec całej kapituły, duchowieństwa i ludu, gdy tedy nowego biskupa z powinszowaniem na tej sesji kapitulnej przyjęto, wyższego też dlań miejsca starsi z powołania członkowie ustąpili”.

Wielicki Maciej biskup (Włoctawek)

nominacja na sufraganię 29 IV $1579^{84}$

Capitulum particulare penultima Aprilis anni 1579. Reverendissimus Dominus, Dominus episcopus [Vladislaviensis] modernus [tj. Stanisław Karnkowski], tanquam pastor vigilantissimus [...], una cum reverendissimis et venerabilibus dominis praelatis et canonicis totoque capitulo [...] unanimi voce elegerunt [et] nominaverunt in suffraganeum ecclesiae cathedralis Vladislaviensis Reverendum Dominum Mathiam Wieliczki, decanum Wladislaviensem, canonicum Sandomiriensem, Pultoviensem, Crusviciensem.

Archiwum Diecezjalne we Włocławku, AKap 5(219), k. 7r (Nominatio suffraganei Domini Wieliczki).

Zatuski Marcin (starszy) biskup (Ptock)

zgon 8 IV $1709^{85}$

${ }^{83}$ Wołoczewski, Biskupstwo żmujdzkie, s. 102; Szostkiewicz, Katalog, s. 576; Nitecki, Biskupi, kol. 458 (31 I 1762).

${ }^{84}$ Szostkiewicz, Katalog, s. 582; Nitecki, Biskupi, kol. 476 (brak daty nominacji; wyłącznie data prekonizacji papieskiej). Nadto: Wiśniewski, Katalog prałatów i kanoników sandomierskich, s. 307 („dnia 29 IV 1579 r. wybrany, zaś 23 I 1581 r. prekonizowany na sufragana włocławskiego").

${ }^{85}$ Nowowiejski, Płock. Monografia historyczna, s. 80 (nr 17); Szostkiewicz, Katalog, s. 593 594; Żebrowski, Zarys dziejów diecezji płockiej, s. 64 (nr 21); Nitecki, Biskupi, kol. 507 (8 IV 1790 [sic]). 
Absolvimus Pascha Heilsbergae cum Domino [Ludovico Bartholomaeo Załuski], episcopo Plocensi, afflicti ex diuturniori et pertinaci fratris nostri suffraganei Plocensis [Martini Załuski] infirmitate, qui [...] 8 $8^{\text {va }}$ Aprilis [1709], ipso die Annunciationis, Heilsbergae, cum omni resignatione in voluntatem Dei et exemplari pietate, Deo spiritum reddidit. Cuius corpus ad capellam s. Stanislai solenniter transtulimus.

Andreae Chrysostomi in Zatuskie Zatuski [...] epistolarum historio-familiarium tomus tertius [1701-1711], Brunsbergae 1711, s. 866 (Mors Martini Zaluski).

Zamoyski Jerzy biskup (Chetm/Krasnystaw), komendatoryjny opat (Czerwińsk) zgon 4 I $[1621]^{86}$

Die 4ta Januarii. [Obitus] Reverendissimi [Domini] Georgii, abbatis Cervenensis, de stirpe Zamoysciorum, episcopi Chełmensis.

BKSC, Liber mortuorum [abbatiae] Czervenensis, s. 58

Zienkowicz Michat Jan biskup (Żmudź - Wilno)

$$
\begin{array}{r}
\text { narodziny } 8 X 1670 \\
\text { sakra } 6 \text { XII } 1718 \\
\text { zgon } 23 \text { I } 1762 \\
\text { pogrzeb 2/3 II } 1762^{87}
\end{array}
$$

1762, Januarius, 23. Hac die Illustrissimus, Excellentissimus ac Reverendissimus Dominus Michaël Joannes Zienkowicz, episcopus Vilnensis, hic Vilnae, in arce episcopali, senio confectus obdormivit in Domino hora $7^{\mathrm{ma}}$ ante mediam noctem. Praelaudatus, piissimus antistes, natus est anno Domini 1670, die 8. Octobris, sacerdos factus anno 1695, canonicus cathedralis Vilnensis anno 1698, consecratus in suffraganeum Samogitiensem 1718, die 6. Decembris. Tandem sacram episcopatus Vilnensis sedem ascendit anno 1730, die 9. Decembris, secundae primitiae sacerdotales celebrandae contingeret anno 1745. Vixit itaque annos 91., menses 3. et dies 15. Eques Albae Aquilae factus est 1736. Post obitum depositus in solario eiusdem palatii adornato iacuit ad $1 \frac{\mathrm{mam}}{\mathrm{m}}$ Februarii, qua die vespertino tempore privatim deductus est ad ecclesiam S. Nicodemi. [...]

${ }^{86}$ Szostkiewicz, Katalog, s. 594; Nitecki, Biskupi, kol. 508 (4 I 1621). Także: Folwarski, Poczet opatów klasztoru kanoników regularnych w Czerwińsku, s. 29 (4 I 1621); Graczyk, Opaci kanoników regularnych z Czerwińska...Czerwieńska, s.136.

${ }^{87}$ Szostkiewicz, Katalog, s. 596-597; Nitecki, Biskupi, kol. 515 („1670-23 I 1762”). Również: Prokop, «Diario Ordinario» oraz «Notizie», s. 145. Nadto: Kawalerowie i statuty Orderu Orła Biatego 1705-2008, s. 166 nr 195. 
1762, Februarius, 2. Conductus funebralis solennis Illustrissimi episcopi Vilnensis, 23. Januarii mortui, ex ecclesia S. Nicodemi $[\ldots]$ absolutus est $[\ldots]$ ad cathedram.

1762, Februarius 3. Sepultura eiusdem Illustrissimi absoluta est. Concionem funebralem habuit cum summo plausu Perillustris Reverendissimus Dominus Chominski, canonicus cathedralis Vilnensis.

APBKr, S-Wi-4, s. 30-31. Także: CVIA, F 1135 ap. 20, k. 156v. („Die 23. Januarii1762. Vespere hora $7^{\mathrm{ma}}$ Illustrissimus, Reverendissimus Dominus Michaël Joannes Zienkowicz, episcopus Vilnensis, nonaginta duorum annorum seniculus, in palatio Vilnensi episcopali obdormivit in Domino. Campanae nullibi sunt pulsati”).

Zienkowicz Tomasz Ignacy biskup (Wilno)

zgon 9 XII 1790 pogrzeb 19 XII $1790^{88}$

1790, December, 9. O godzinie siódmej wieczorem oddał ducha Bogu JW. JX. Tomasz Zienkowicz, biskup areopag[ieński] [sic!], zostawiwszy nieokojony żal całej powszechności; który był dla wszystkich przykładem świątobliwego życia. 1790, December 19. Kondukt JW. JX. biskupa Zienkowicza, którego [ciało] prowadzono od XX. Karmelitów Bosych do Świętego Jana.

APBKr, S-Wi-5, s. 313-314 (tamże, s. 315: „1790, December, 21. Wigilia za duszę śp. JW. JX. Tomasza biskupa Zienkowicza). Zob. również: APBKr, S-Wi-4, s. 30: „1762, Januarius, 29. Hac die venerabile ac illustrissimum capitulum Vilnense in administratorem spiritualem sede vacante elegit Illustrissimum, Reverendissimum Dominum Thomam Zienkowicz, episcopum Ariopolitanum, suffraganeum Albae Russiae, cui consiliarios addidit Perillustres Reverendissimos Dominos Thomam Korsak, Stephanum Giedroyć et Casimirum Prozor, canonicos Vilnenses. In temporalibus vero elegit in administratorem Perillustrem Reverendissimum Dominum Carolum Karp, canonicum cathedralem Vilnensem").

[Kanonicy katedry wileńskiej zebrali się] z powodu smutnej wieści o zejściu w dniu 9 [XII 1790] biskupa Tomasza Zienkowicza, sufragana, który w kapitule z kanonika na prałaturę kustodii, a później na dziekanię postąpiwszy, w tejże diecezji naprzód białoruskim, później zaś wileńskim będąc sufraganem, w publicznem też krajowem urzędowaniu, pierwej pisarzem, potem sekretarzem Wielkiego Księstwa Litewskiego, chwalebnie spełniał obowiązki przez lat 50 bycia swego w kapitule, który miał łączyć w roku następnym 1791 i drugie prymicje w miesiącu lipcu mieć mający, dla swoich zasług od tejże kapituły jubilowany, a pełniejszy wielkich cnót, powszechnie od wszystkich dla wielkiej świątobliwości i pobożnych uczynków szanowany i wielbiony, po pięciodniowej chorobie, na dniu 9.

${ }^{88}$ Wołonczewski, Biskupstwo zmujdzkie, s. 94; Szostkiewicz, Katalog, s. 597; Nitecki, Biskupi, kol. 458 (rok 1790). Nadto: Kawalerowie i statuty Orderu Orła Białego 1705-2008, s. 202 nr 480. 
tego miesiąca, o godzinie siódmej wieczór, śmiertelne na wieczne życie zamienił. Za tym prześwietna kapituła, oświadczywszy swój żal i smutek nad utratą godnego i ze wszech miar szanowanego swego konfratra, postanowiła tak w kondukowaniu zwłok jego z kościoła JJ. XX. Bosaków [tj. karmelitów bosych] do św. Jana dla odprawienia tamże pogrzebowego obchodu, jako też w przeprowadzeniu na ostatek do katedralnego kościoła i grobu tamże po dwudniowych egzekwiach, czynić jak najskwapliwiej i najokazalej zeszłemu ostatnią posługę.

LMAB, F 9 - 162-166, cz. 2, k. 51v (sesja kapituły wileńskiej w dniu 11 XII 1790).

\section{Żochowski Cyprian metropolita (Kijów), arcybiskup (Polock)}

Anno Domini 1693, die vero 26. Octobris, fatis cessit dominus metropolitanus Russiae, Kiioviensis et Haliciensis, archiepiscopus Polocensis. Post cuius fata in spiritualibus data est mihi Leoni Szlubic Załęski, Vladimiriensi et Brestensis ritus uniti Graeci episcopo, ab Illustrissimo nuntio apostolico Andrea Sancta Crucio, in temporalibus vero a Serenissimo, Potentissimo Poloniarum rege Joanne III., administratio eiusdem metropoliae iam circa medium Novembrem eiusdem anni 1693.

ASPF, Scritture riferite nei Congressi: Moscovia, Polonia e Ruteni, vol. 2, k. 417r (20 VI 1694). Zob. również: tamże, k. 514r-v (Professio fidei Leona Załęskiego, jako metropolity Rusi), 515r$516 \mathrm{v}$ (Iuramentum fidelitatis Leona Załęskiego, jako metropolity Rusi).

Żótkowski Antoni Józef biskup (Wilno)

narodziny 6 VI 1686 zgon 19 I 1763 pogrzeb 21 I $1763^{90}$

1763, Januarius, 19. Illustrissimus ac Reverendissimus Dominus Antonius Josephus Zołkowski, episcopus Alaliensis, suffraganeus et decanus cathedralis Vilnensis, speciali zelo, laboribus, prudentia caeterisque dotibus commendatus, hac die post meridiem hanc vitam finivit. Praelaudatus illustrissimus natus est anno 1686, die 6. Junii, functus est officiis archidiaconi Albae Russiae, canonici,

${ }^{89}$ Epistolae metropolitarum Kioviensium catholicorum: Cypriani Zochovskyj, Leonis Slubicz Zalenskyj, Georgii Vynnyckyj-1674-1713, ed. A.G. Welykyj, Romae 1958, s. 7. Por.: Blazejowskyj, Hierarchy of the Kyivan Church, s. 251, 283; tenże, Іерархія Київської Церкви (861-1996), s. 251, 283. Nadto: Jakubowski, Solarczyk, Organizacja Kościoła rzymsko-katolickiego na ziemiach polskich, s. 256, 263.

${ }^{90}$ Szostkiewicz, Katalog, s. 597; Nitecki, Biskupi, kol. 522 („6 VI 1686-1763”); Prokop, «Diario Ordinario» oraz «Notizie», s. 145. 
custodis et officialis Vilnensis ac decani, suffraganei Albae Russiae, tandem suffraganei Vilnensis ab anno 1755.

1763, Januarius, 21. Eadem die vespertino tempore absolutus est solemnis funebralis conductus Illustrissimi Zołkowski, episcopi Alaliensis, ad ecclesiam cathedralem, conducente Illustrissimo Domino Horain, suffraganeo Samogitiense, in assistentia capituli, Patrum Dominicanorum, [Fratrum Minorum] Conventualium, nostrorum [tj. franciszkanów obserwantów] et Carmelitarum S. Georgii.

APBKr, S-Wi-4, s. 50-51. Także: CVIA, F 1135 ap. 20, k. 156v. („Die 19. Januarii 1763. Illustrissimus suffraganeus Vilnensis Zołkowski, optime dispositus, fatis cessit a prandiis circa $2^{\frac{\mathrm{dam}}{2}}$ horam"). Zob. nadto: LMAB, F 9 - 162-166, k. 61r (21 II 1745).

\section{WYKAZ POSTACI UWZGLĘDNIONYCH W CZĘŚCIACH I - XII}

W indeksie zbiorczym do wszystkich dotychczasowych części Wypisów źródtowych obowiązuje układ alfabetyczny - dla postaci z czasów nowożytnych według nazwisk, dla nielicznego grona hierarchów z późnego średniowiecza podług imion. W pierwszej kolejności wskazano - za pomocą cyfry rzymskiej, umieszczonej w nawiasie zwykłym (półokrągłym) - na część (części) cyklu, w której (których) pomieszczone zostały świadectwa dotyczące konkretnej osoby. Następnie, w nawiasie kwadratowym, podano cyframi arabskimi numer tomu półrocznika „Archiwa, Biblioteki i Muzea Kościelne”, w którym dana część Wypisów źródłowych została opublikowana, oraz - po dwukropku - oznaczenie stron, gdzie znajduje się stosowna zapiska. Aby maksymalnie ułatwić komuś sięgającemu do kontynuowanej w latach 2004-2013 edycji źródłowej zyskanie orientacji w zgromadzonym przez wydawcę materiale, indeksem objęto także pokrewnego charakteru edycje, zamieszczone w „Archiwach, Bibliotekach i Muzeach Kościelnych”, a dotyczące prozopografii staropolskiej hierarchii kościelnej, oznaczone tu następującymi syglami:

BT $=$ Polonica $\mathrm{w}$ katalogu obsady biskupstw tytularnych XVII-XIX w. z Archivio

Segreto Vaticano (ASV), „Archiwa, Biblioteki i Muzea Kościelne” 93 (2010), s. $175-209$

DO $=$ «Diario Ordinario» oraz «Notizie» rzymskich drukarzy Cracas (Chracas) jako źródto informacji do dziejów hierarchii Kościoła katolickiego w Rzeczypospolitej Obojga Narodów u schytku epoki staropolskiej, „Archiwa, Biblioteki i Muzea Kościelne" 90 (2008) s. 111-146

IP = Polonica $z$ drugiej połowy XVII oraz z XVIII i XIX w. w zbiorze «Iuramenta fidelitatis et Professiones fidei» z Archivio Segreto Vaticano (ASV), „Archiwa, Biblioteki i Muzea Kościelne" 93 (2010) s. 211-258

WG = Wiadomości genealogiczne $i$ dotyczace wydarzeń historycznych $w$ księgach święceń biskupów krakowskich (głównie sufraganów) z drugiej połowy XVII i z XVIII wieku, „Archiwa, Biblioteki i Muzea Kościelne” 81 (2004) s. 199223 
$\mathbf{W P}=$ Wiadomoścido biografii biskupóworazopatówiksieńz ziem Rzeczypospolitej

Obojga Narodów z osiemnastowiecznej prasy warszawskiej doby saskiej i stanisławowskiej (1729-1795), „Archiwa, Biblioteki i Muzea Kościelne” 86 (2006) s. 287-329

W powyższym kontekście należy zaznaczyć, że nie chodzi o pełny indeks także do owych «bliźniaczych» edycji, lecz wyłącznie o wskazanie na obecność tam informacji poszerzających wiedzę o postaciach uwzględnionych w ramach cyklu, do którego odnosi się poniższy wykaz. Innymi słowy tych duchownych, których nazwiska pojawiają się wyłącznie w wyżej wskazanych, pokrewnych publikacjach materiałowych, wszakże nie w Wypisach źródłowych, pominięto w niniejszym zestawieniu. Obejmuje ono łącznie 683 postacie z wieków XVXIX.

Albinowski Andrzej biskup (III) [84:276-277]

Albrychowicz Fortunat opat (V) [87:121] • WG [81:221] • WP [86:294]

Aleksandrowicz (Witold-AleKsandrowicz) Jan Alojzy biskup (IX) [95:253] •

WP [86:295]

* Andrzej [z ?] opat (V) [87:149]

AnkwICZ Andrzej Alojzy arcybiskup (III) [84:241-242], (X) [97:222] • IP [93:163]

* Antoni, syn Mikołaja biskup (X) [97:221]

ArCemberski Walenty Maciej biskup (X) [97:222-223] • IP [93:163]

Augustynowicz Jakub Stefan arcybiskup (II) [83:292] • WP [86:295] • DO [90:126]

AugustynowICZ Jan Tobiasz arcybiskup (II) [83:292] • WP [86:295]

BAJER Andrzej Ignacy biskup (III) [84:287], (VII) [91:298-299, 317] • WP [86:295] • DO [90:126]

BAJKowsKi Jan biskup (X) [97:223]

BARANIECKI Lukasz arcybiskup (III) [84:242] • IP [93:164]

BARANOWSKI Stanisław opat (VI) [89:367-368]

BARANOWSKI Wincenty opat (V) [87:150]

BARANOWSKI Wojciech arcybiskup (XI) [98:313]

BARDZIŃSKI Wojciech Ignacy biskup (I) [82:200], (III) [84:243, 277], (VIII) [94:202], (X) [97:223-224] • IP [93:164-165]

BartoszowsKi (Bartoszewski) Stanisław Benedykt opat (IV) [85:313] • WP [86:296]

BATORY Andrzej administrator opactwa, kardynał (XII) [99:172-173]

BĄIEWICZ Klemens Andrzej biskup-nominat (II) [83:293]

BEDLIŃski Stanisław biskup (X) [97:224]

BENISŁAWSKI Jan (X) [97:224-225] • WP [86:296] • DO [90:126]

BEREŚNIEWICZ Aleksander Kazimierz biskup (III) [84:243] • IP [93:165]

BERNATOWICZ Jan biskup (XII) [99:173]

Betański Antoni Waclaw biskup (X) [97:225-226] • DO [90:126]

BIALOBцосKI Kazimierz Jan opat (XI) [98:365], (XII) [99:144-145] 
Biatobrzeski Stanisław opat (VI) [89:368]

BIDZIŃski Celestyn opat (XII) [99:145]

BIEDRZYCKI Wojciech opat (XI) [98:365]

Bobrownicka Joanna Katarzyna ksieni (V) [87:121]

BoglewSKI Stanisław administrator opactwa (XI) [98:365-366]

Bokum (de Alten Bokum) Jan Kazimierz biskup (VII) [91:299, 317], (XI) [98:313]

BoROWSKI Franciszek administrator opactwa (IV) [85:314] • WP [86:296]

Borowski Kasper biskup (III) [84:244] • IP [93:165]

Borowski Piotr opat (VI) [89:368-369]

Borzobohata Wiktoria Katarzyna ksieni (XII) [99:145-146]

BorzysŁawsKi (BorysŁawsKi) Stanisław opat (III) [84:274]

BRATKOWSKI Onufry opat (XI) [98:366]

BrodzISzewsKi Wojciech Anzelm biskup (II) [83:293], (X) [97:226-227]

BrzechWA Andrzej opat (VI) [89:369]

BrzeCHWA Kazimierz opat (XII) [99:146]

Brzostowski Konstanty Kazimierz biskup (V) [87:134], (X) [97:227]

BUJDECKI Florian prepozyt generalny (XI) [98:366-367]

BuJdecki Mateusz prepozyt generalny (V) [87:150]

Bukaty Tadeusz Józef biskup (XII) [99:173-174] • DO [90:126] • BT [93:207]

BuŁaKowski Jan Robert opat (II) [83:320-321], (XI) [98:367-368]

Burzyński Adam Prosper biskup (V) [87:134-135] • IP [93:166]

Bystram Maciej biskup (VII) [91:300], (X) [97:227]

Bystram Remigian Tadeusz Wilhelm opat (XI) [98:368]

Bystram Zygmunt Karol Jan Nepomucen opat (XI) [98:368-369]

BystrzyCKI Jowin Fryderyk biskup-nominat (III) [84:244-245], (VI) [89:349], (VIII) [94:202-203]

Calowański Stanisław biskup (V) [87:135], (VIII) [94:203]

Charbicki Krzysztof biskup (VIII) [94:203], (X) [97:227-228]

Chelkowski Józef biskup (III) [84:245] • IP [93:166]

Chmielewski Tomasz biskup (II) [83:294]

Chocimowska Maryna (Marianna) Teofila ksieni (V) [87:121-122, 135]

Choloniewski Andrzej biskup (III) [84:245-246]

Chомiński Michał Józef biskup (IX) [95:253-254], (XII) [99:174-175] • DO [90:127]

ChoromańsKi Stanisław arcybiskup (XI) [98:314] • BT [93:127] • IP [93:166]

Снотек Ferdynand Maria arcybiskup (X) [97:228-229] • IP [93:166-167]

Chrzanowska Benedykta ksieni (XII) [99:146]

Chrząstowska Anna ksieni (V) [87:122, 135-136]

Chrząstowska Krystyna ksieni (V) [87:122-123]

Chyczewski Marcin biskup (II) [83:294] • DO [90:127]

Cieciszowski (Cieciszewski) Kasper Kazimierz arcybiskup (IX) [95:254], (X) [97:229] • DO [90:127] • IP [93:167]

Cielecki Hieronim biskup (IV) [85:314-315] 
CieszeJKo Amand Wiktoryn biskup (VIII) [94:234]

CieszKowski Krystyn biskup (IX) [95:254-255], (X) [97:229-230]

Cyвichowski Józef biskup (III) [84:246]

Czapski Tomasz Franciszek biskup (VII) [91:300-301], (VIII) [94:234] • WP [86:298]

CzAPski Walentyn Aleksander biskup (III) [84:277-278, 287], (IX) [95:255], (X) [97:230], (XI) [98:314] • WP [86:298] • DO [90:127]

Czarnecki Józef Augustyn biskup (IX) [95:256] • IP [93:167]

Czartoryski Kazimierz Florian arcybiskup (IV) [85:315], (IX) [95:292-293]

Czartoryski Teodor Kazimierz biskup (I) [82:200-201], (IV) [85:315-316], (VIII) [94:203-204] • WP [86:298] • DO [90:127]

Czermiński Lukasz Jacek biskup (IV) [85:316], (X) [97:231]

Czolnański Jan Karol biskup (I) [82:201], (V) [87:136], (XI) [98:369-370]

Czulski Walentyn Konstanty biskup (VIII) [94:235], (X) [97:231]

Czyżowski Zygmunt biskup (VI) [89:357-358], (VIII) [94:204]

DąBRowski Jan biskup (X) [97:231-232] • IP [93:168]

DĄMBSKa Lidwina ksieni (VII) [91:296]

DĄмвSKI Stanisław Kazimierz biskup (I) [82:201], (VIII) [94:204-205], (IX) [95:293], (XI) [98:314-315]

DEDERKo Jakub Ignacy biskup (II) [83:326], (X) [97:232]

Delamars (De la Mars) Michał biskup (IV) [85:317], (VIII) [94:235], (X) [97:233]

Dembowski Antoni Sebastian biskup (III) [84:278, 288], (VII) [91:290, 291292], (X) [97:233] • WP [86:298] • DO [90:127-128]

Dembowski Jan (starszy) biskup (III) [84:288-289], (VIII) [94:205], (X) [97:234] - WP [86:298-299] • DO [90:128]

Dembowski Jan (młodszy) biskup (VI) [89:350] • WP [86:299] • DO [90:128]

Dembowski Mikołaj biskup (III) [84:278], (IV) [85:317], (VIII) [94:206] • WP [86:299] • DO [90:128]

Dembski (DęBSki) Pawel biskup (IV) [85:317-318]

DenhofF Aleksander administrator opactwa (koadiutor) (XII) [99:146-147]

Denhoff Jan Kazimierz administrator opactwa, kardynał (I) [82:195], (VIII)

[94:206], (XI) [98:370], (XII) [99:147]

Denhoff Jerzy Albrecht biskup (IV) [85:318], (VIII) [94:207], (IX) [95:294], (XI) [98:315-316] • IP [93:168]

DŁugoŁęCKI Stanisław opat (XII) [99:147-148]

DŁUSKI Ignacy Łukasz biskup (IX) [95:256] • DO [90:128]

Dмосношsкi Kazimierz arcybiskup (X) [97:234], (XI) [98:316] • IP [93:169]

Dobiński Krzysztof Michal biskup (IX) [95:256-257], (X) [97:234-235] • WP [86:299] • DO [90:128]

Dobriolanus Szymon biskup (X) [97:235]

Dobrowska Marcelianna przełożona (XI) [98:370-371]

Domaniewski Stanisław biskup (III) [84:279] • IP [93:169] 
Dowgiallo Zawisza Stanisław Kazimierz biskup (X) [97:235-236] - WP [86:299] • DO [90:128]

Dubrawski Pawel Konstanty biskup (VIII) [94:236]

DunAJEwSKI Albin kardynał (IX) [95:294-295]

Dunin (Sulgustowski) Marcin arcybiskup (X) [97:236] • IP [93:169-170]

DZIAŁYŃski Aleksander Tomasz biskup (III) [84:279], (IX) [95:257], (X) [97:236-237]

DZIAŁYŃSKI Kasper biskup (VII) [91:317-318], (X) [97:237-238]

DZIAŁYŃsKi Michał Erazm biskup (IV) [85:319]

DzIĘCIELSKI Józef Marcelin biskup (III) [84:246], (XI) [98:316-317] • IP [93:170]

DzіокошsкI Józef opat (XI) [98:371]

* Edmund a Cruce opat (II) [83:321]

FALĘCKI Stanislaw opat (XII) [99:148]

FelińsKi Zygmunt Szczęsny arcybiskup (III) [84:247] • BT [93:127] • IP [93:170]

FERBER Maurycy biskup (VII) [91:301]

FIAŁKowSKI Antoni arcybiskup (III) [84:247-248], (X) [97:238] • IP [93:170]

FIaŁKowsKi Antoni Melchior arcybiskup (XI) [98:317] • IP [93:170-171]

FIRLEJ Henryk (starszy) administrator opactwa, arcybiskup (VI) [89:369-370], (VIII) [94:207], (XI) [98:317-318]

FirLeJ Henryk (młodszy) administrator opactwa, biskup (VI) [89:370-371], (VIII) [94:207-208], (XI) [98:318-319]

Fredro Aleksander Antoni biskup (II) [83:326], (XI) [98:319]

FreDro Mikołaj Gabriel biskup (X) [97:238-239]

FukIER Jan infułat (II) [83:321]

Gadomski Wojciech Józef biskup (V) [87:136-137], (VIII) [94:208] • WP [86:299] • DO [90:128]

GaŁECKI Antoni biskup (III) [84:248] • BT [93:128]

GARAMPI Giuseppe kardynał (XI) [98:319-320] • DO [90:118]

GARNYSz Maciej Grzegorz biskup (VIII) [94:208-209], (IX) [95:257-258], (XI) [98:320] • WP [86:299-300] • DO [90:129]

GaWroński Andrzej biskup (III) [84:249], (IV) [85:319] • DO [90:129] • IP [93:171]

Gembart (GEMbarth) Józef biskup (I) [82:202], (III) [84:249-250], (V) [87:137], (X) [97:239]

GeMBICKI Andrzej biskup (X) [97:239-240]

GeMвICKI Jan biskup (IV) [85:320], (VI) [89:371], (VII) [91:318], (XI) [98:320] - IP [93:171]

GembickI Piotr administrator opactwa, biskup (IV) [85:321], (VI) [89:371-372], (VIII) [94:209], (XI) [98:321]

GemвICKI Wawrzyniec arcybiskup (IV) [85:321-322], (VIII) [94:209-210], (X) [97:240] 
Geritz Józef Ambroży biskup (II) [83:295], (VII) [91:290-291, 292-293, 318319], (X) [97:240-241] • BT [93:127] • IP [93:171]

GHigiotTi Kajetan (Gaetano) administrator opactwa (XI) [98:371-372]

GIEDROYĆ Ignacy biskup (II) [83:295-296] • IP [93:171-172]

GIEDRoyć Jan Stefan biskup (IX) [95:258], (X) [97:241], (XI) [98:321-322] • WP [86:300] • DO [90:129]

Giedroyć Józef Arnulf Michał biskup (II) [83:296] - WP [86:300] • DO [90:129]

GIEDROYĆ Szymon Michal biskup (III) [84:250] • BT [93:127] • IP [93:172]

GIEDZıŃsKI Jerzy biskup (II) [83:327]

Gintowt (Dziewaltowski-Gintowt) Aleksander Kazimierz arcybiskup (XII) [99:175]

GLAZER Jakub biskup (X) [97:242]

GlowIŃsKI Samuel biskup (IX) [95:258-259] • WP [86:300]

GNIEwosz Mikołaj Wojciech administrator opactwa, biskup (IV) [85:322], (VI) [89:372-373], (XI) [98:322]

GNIŃSKI Bernard Ignacy opat (V) [87:123], (XII) [99:149]

GNiśski Jan Benedykt biskup (II) [83:296-297]

GNIŃSKI Samuel Jan opat (V) [87:123]

Goldtmann Józef Joachim biskup (II) [83:297], (X) [97:242], (XI) [98:322 $-323]$

GolaszewSKI Antoni biskup (X) [97:242-243] • WP [86:300] • DO [90:129] • IP [93:172]

GoŁASZEwSKI Jan Klemens biskup (X) [97:243] • IP [93:172]

GoMoliński Jan Pawel biskup (VIII) [94:210, 236]

GoMoLIŃski Stanisław biskup (XI) [98:323]

GoRCZYŃSKI Antoni biskup (IX) [95:259], (X) [97:243-244] • IP [93:172]

GoRzeńsKI Tymoteusz arcybiskup (II) [83:297], (IV) [85:323] • WP [86:300] • IP [93:173]

GosiewsKI Boguslaw biskup (XI) [98:323-324] • BT [93:127]

Gostomski Jan administrator opactwa (IV) [85:323-324], (VI) [89:373-374]

GośLICKI Wawrzyniec administrator opactwa, biskup (VI) [89:374], (X) [97:244]

GóRSKI Ludwik Stanisław biskup (IX) [95:302-303] - DO [90:129] • IP [93:173]

GóRSKI Wojciech Józef biskup (VI) [89:358-359], (X) [97:244-245], (XII) [99:175-176]

GrABIŃSKI Aleksander opat (III) [84:274-275]

GrabOWSKI Adam Stanisław biskup (VII) [91:301-302], (IX) [95:259-260], (XI) [98:324] • WP [86:301] • DO [90:129-130]

GraBowsKi Joachim Józef biskup (II) [83:298]

GrabowsKI Wojciech biskup (IV) [85:324] • BT [93:128]

GrochowsKi Achacy biskup (IV) [85:324]

Grochowski Stanisław arcybiskup (IV) [85:325], (XI) [98:324]

Grossman Franciszek biskup (VII) [91:302], (X) [97:245] • IP [93:173] 
Gruszecki Stefan Eustachy opat (VI) [89:350-351], (XI) [98:372]

GrzYBKowski Leobald opat (XI) [98:373]

GuMienieckA Teresa ksieni (V) [87:137, 151]

Gumieńska (GumińsKa) Bogumiła Magdalena ksieni (VI) [89:374-375]

GurowsKi Aleksander Benedykt opat (XII) [99:149]

Gurowski Aleksander Melchior opat (XI) [98:373-374] • WP [86:301]

GURowskI Józef Bernard opat (II) [83:322], (XII) [99:150]

GuTKowski Jan Marceli biskup (II) [83:298-299] • BT [93:126] • IP [93:173]

Gutowski Wawrzyniec biskup (II) [83:299] • IP [93:173-174]

GzowsKI Franciszek biskup (X) [97:245], (XII) [99:176-177] • WP [86:301] • DO [90:130]

НАвіснт Bartlomiej opat (VI) [89:375-376]

HACKI Michal Antoni opat (XII) [99:150]

DE Hatten Andrzej Stanisław biskup (III) [84:250-251], (VII) [91:291, 293294], (X) [97:246] • IP [93:174]

Hirschler Maciej biskup (III) [84:251] • IP [93:174]

HohenzollerN-Hechingen Jan Karol biskup (VII) [91:294], (IX) [95:260-261], (X) [97:246-247], (XI) [98:324-325] • DO [90:130] • IP [93:174]

HohenzollerN-Hechingen Józef biskup (III) [84:251-252], (X) [97:247] • IP [93:174]

HoŁowczyc Szczepan arcybiskup (III) [84:252], (IV) [85:325], (XI) [98:325] • IP [93:174-175]

HoŁowIŃSKI Ignacy arcybiskup (III) [84:253] • IP [93:175]

HoraIn Aleksander Mikołaj (starszy) biskup (XI) [98:325-326] • WP [86:301] • IP [93:175]

HoraIn Aleksander (młodszy) biskup (X) [97:247], (XII) [99:177-178] • WP [86:301-302]

HoRBACKI Gedeon arcybiskup (XI) [98:362] • WP [86:302] • DO [90:130]

HozJusz Stanisław Józef biskup (I) [82:202], (IV) [85:326], (X) [97:248], (XI) [98:326], (XII) [99:178] • WP [86:302]

HREBNICKI Florian arcybiskup (XI) [98:363] • DO [90:130]

Hylzen (Hilzen, Hülzen) Jerzy Mikołaj biskup (XII) [99:179] • WP [86:302] • DO [90:130]

IŁoWIECKI Konstantyn opat (XI) [98:374]

IsAKoWICZ Izaak Mikotaj arcybiskup (X) [97:322-323]

IZDEBSKI Wojciech biskup (II) [83:299-300]

JABLONOWSKI Romuald opat (XI) [98:375]

* Jan z Męciny opat (V) [87:151]

JANISZEwSKI Jan Chryzostom biskup (III) [84:253]

JANOwSKI Florian Amand opat, biskup (V) [87:119], (VI) [89:354], (X) [97:248]

- WP [86:302-303] • IP [93:176]

JAWORowSKI Leon biskup (X) [97:323-324] 
JeŁowicki (JaŁowicki, JeŁowiecki) Hieronim Maciej biskup (I) [82:195-196],

(IV) [85:326], (XI) [98:326-327] • WP [86:302]

JEZIERSKI Stanisław Rajmund biskup (IX) [95:261], (X) [97:249], (XII) [99:179]

-WP [86:303] • DO [90:131]

Јорко (Јотко, Јорка) Aleksander opat (XI) [98:375-376]

JoRDAN Jan opat (VI) [89:376]

KACZKowsKI Jan Chryzostom biskup (IX) [95:262] • DO [90:131]

KAHN Ferdynand Ignacy Helaniusz biskup (III) [84:254] • IP [93:177]

KAMIONKo (KAMIONKA) Walery Henryk biskup (III) [84:254] • BT [93:127] • IP [93:177]

KANIGOWSKI Franciszek biskup (III) [84:280], (VIII) [94:211] • WP [86:303] • DO [90:131]

KARNKOWSKI Stanislaw arcybiskup (II) [83:318-319]

KARP Jozafat Michal biskup (IX) [95:262], (X) [97:249] • WP [86:303] • DO [90:131]

KARSKI Jan biskup (IX) [95:262-263] • WP [86:303] • DO [90:131]

KARSKI Teodor opat (IX) [95:303]

Karwosiecki Dominik Kajetan Piotr biskup (IX) [95:263], (X) [97:249-250] • DO [90:131]

KaznOwSKI Franciszek biskup (I) [82:196], (X) [97:250] • WP [86:303] • IP [93:177]

KeCK Udalryk opat (VIII) [94:236-237]

KEcSOWSKI Aleksander opat (III) [84:275]

KICKI Ferdynand Onufry Bazyli arcybiskup (I) [82:203], (IV) [85:327], (IX) [95:264], (X) [97:250-251], (XI) [98:327] • DO [90:131] • IP [93:177-178]

KICKI Kajetan Ignacy biskup (X) [97:251-252] • DO [90:132] • IP [93:178]

KIElCZEWSKI Dominik Józef biskup (I) [82:203], (IV) [85:327], (X) [97:252], (XII) [99:179-180] • WP [86:303] • DO [90:132]

KIERSKI Józef Tadeusz biskup (IX) [95:264-265], (X) [97:253] • WP [86:303 -304] • DO [90:116] • DO [90:132]

Kirkorowiczówna (Teodorowiczówna) Ksaweria Gertruda ksieni (VII) [91:297]

KISZKA Stanisław biskup (III) [84:289 $]^{91}$

KŁĄGIEWICZ Andrzej Benedykt biskup (III) [84:254-255], (X) [97:253] • IP [93:178]

KŁoкосKI Adam biskup (II) [83:300]

Knutowna Dorota ksieni (VII) [91:297]

KoBIELSKI Franciszek Antoni biskup (I) [82:196-197], (IV) [85:328], (VIII) [94:237-238], (XI) [98:327-328] • WP [86:304] • DO [90:132]

Kochanowska Anna ksieni (VI) [89:355]

KochNOwSKI Melchior Jan biskup (IX) [95:265] • WP [86:304] • DO [90:132]

${ }^{91}$ Wydane świadectwo źródłowe, odnoszące się do biskupa żmudzkiego Stanisława Kiszki, mylnie zinterpretowano jako informujące o jego ingresie do świątyni katedralnej, o czym w rzeczywistości mowy tam nie ma. 
KoMORNICKI Franciszek biskup (IX) [95:265-266] • WP [86:304]

KomorNICKI Michal Hieronim opat (XII) [99:151]

Komorowski Adam Ignacy arcybiskup (III) [84:280-281], (IV) [85:328-329], (VIII) [94:238], (X) [97:254-255] • WP [86:304] • DO [90:132]

Komorowski Antoni Jakub administrator opactwa (VI) [89:376]

Komorowski Jan Adam administrator opactwa (IV) [85:329]

KonARSKI Dawid opat (III) [84:275]

KONARSKI Michal opat (III) [84:276]

Konarzewski Antoni Eugeniusz opat (XI) [98:376-377] • WP [86:305]

KonIECPOLSKI Remigiusz administrator opactwa, biskup (VI) [89:359, 377], (XII) [99:151]

KonOPACKI Maciej biskup (VII) [91:302-303]

KonTSKI Antoni opat (XII) [99:151-153]

KoRCZYŃSKI Michal Tomasz biskup (III) [84:255-256]

KorN (KoRŃ) Maciej opat (XI) [98:377]

KORYCIŃSKI Wojciech Jan arcybiskup (IV) [85:330], (XI) [98:328]

KoryTowski Józef Benedykt biskup (IX) [95:266], (X) [97:255] • DO [90:132]

Kos (Koss) Adam biskup (X) [97:255-256]

KosIŃSKI Leon Emilian opat (II) [83:322]

Kosmowski Michał biskup (II) [83:300] • WP [86:305]

KossaKowsKi Adam biskup (II) [83:301] • DO [90:133]

KossaKowsKI Jan Nepomucen biskup (II) [83:301], (IX) [95:295], (XII) [99:180]

- DO [90:133]

Kossakowski Józef Kazimierz biskup (IX) [95:266-267] • WP [86:305] • DO [90:133]

KosteckI Jan opat (XII) [99:153] • WG [81:210]

Kostka Piotr biskup (VII) [91:303]

KośCIA Adam biskup (IX) [95:267] • WP [86:305]

KoWALSKI Kajetan biskup (III) [84:256] • IP [93:179]

KozIERowski (Koziorowski) Ignacy Augustyn biskup (IX) [95:267-268] • WP [86:305] • BT [93:127-128]

KoźMIAN Józef biskup (III) [84:256] • IP [93:179-180]

KoźMIŃSKA (KoźMIEŃSKA) Ludwika ksieni (XII) [99:153-154]

KoźMIŃSKI Kasper opat (VI) [89:377-378]

KRASICKI Ignacy Franciszek Błażej arcybiskup (IX) [95:268], (XI) [98:328329], (XII) [99:181] • WP [86:305-306] • DO [90:133] • IP [93:180]

KrasiŃSKI Adam Stanisław (starszy) biskup (VIII) [94:211-212] • WP [86:306] - DO [90:133]

KrasińSKI Adam Stanisław (młodszy) biskup (III) [84:257] • IP [93:180]

KrASIŃSKI Franciszek biskup (I) [82:203-204, 221], (X) [97:256]

KRASIŃSKI Jan biskup (VII) [91:303-304], (VIII) [94:212] • WP [86:306] • DO [90:133]

KRASSOWSKI Jan arcybiskup (X) [97:324]

Kraszewski (Kraszowski) Antoni Józef Daniel opat (V) [87:123-124] • WP [86:306] 
Kraszewski Mateusz opat (XII) [99:154]

KraszKowsKI Franciszek biskup (X) [97:256-257] • WP [86:306]

KretKowsKi Feliks Ignacy biskup (VII) [91:304, 319], (X) [97:257-258] • WP [86:306]

KRĘSI Stanisław administrator opactwa (IX) [95:304]

Kromer Marcin biskup (X) [97:258-259]

Krosnowski Mikołaj arcybiskup (XI) [98:329], (XII) [99:181]

KrZESIMOWSKI Antoni opat (XII) [99:154-155] • WG [81:210]

KRZYŻanOWSKI Hieronim opat (VI) [89:378]

KrzYŻANOwSKI Ignacy Franciszek biskup (IX) [95:268-269]

Kuczborski Jan biskup (IV) [85:330], (VII) [91:304-305]

KuCzowski Andrzej opat (V) [87:151-152]

KundzICz Tadeusz biskup (III) [84:257-258] • BT [93:129] • IP [93:180-181]

KUNICKI Michal Ignacy biskup (I) [82:197], (IV) [85:331], (X) [97:259] • WP [86:306-307]

KurdwanowsKi Jan Franciszek biskup (IV) [85:331-332], (VII) [91:305], (X) [97:259-260] • IP [93:181]

KuRdWANOwSKI Józef Wawrzyniec opat (V) [87:124] • WP [86:307]

KURSKI Maciej Marian biskup (X) [97:260] • BT [93:128]

Kutowski Jan Stanisław biskup (II) [83:302] • IP [93:181]

Lascaris (LASkary) Jerzy Maria patriarcha (X) [97:260-261], (XII) [99:181183] • WP [86:307] • BT [93:126]

LAskowska Marianna ksieni (II) [83:323]

Ledóchowski Mieczysław kardynał (III) [84:258-259] • BT [93:127] • IP [93:181]

Lenczowski Jan Kanty biskup (VI) [89:351], (VIII) [94:239], (IX) [95:269] • DO [90:134] • BT [93:127] • IP [93:181]

LESKI Wojciech Stanisław biskup (III) [84:281], (X) [97:261] • WP [86:307] • DO [90:134]

LesZCZYŃsKI Andrzej arcybiskup (IV) [85:332], (VIII) [94:212-213], (XI) [98:330]

LESZCZYŃSKI Andrzej administrator opactwa (XII) [99:155]

LESZCZYŃSKI Bogusław Franciszek biskup (VIII) [94:213]

LESZCZYŃSKI Jan biskup (VIII) [94:213-214]

LESZCZYŃSKI Rafał biskup (X) [97:261-262]

LESZCZYŃsKI Wacław arcybiskup (IV) [85:332-333], (VII) [91:319], (XI) [98:330-331]

LEWICKI Józef biskup (X) [97:325]

LEWICKI Michat metropolita (X) [97:325-326]

LEWIŃSKI Feliks Lukasz biskup (XI) [98:331] • DO [90:134] • IP [93:181]

LEWIŃSKI Franciszek Ignacy biskup (II) [83:302] • IP [93:181]

LEŻEŃSKI Kazimierz Benedykt biskup (X) [97:262]

LEŻEŃSKI Mikołaj opat (IV) [85:333] 
LeżeńsKI Tomasz biskup (IV) [85:333-334], (VIII) [94:214], (X) [97:262], (XI) [98:332]

LEŻYŃSKA (LEŻEŃSKA) Katarzyna ksieni (II) [83:323], (V) [87:124-125] • WP [86:307]

LiNTFaRI Marcin biskup (X) [97:263]

LIPNICKI Wojciech biskup (IV) [85:224], (X) [97:263]

LIPSKA Anna Rozalia ksieni (VI) [89:378-379]

LIPSKI Andrzej biskup (IV) [85:334-335], (VIII) [94:214]

LIPSKI Jan arcybiskup (IV) [85:335], (VII) [91:320], (VIII) [94:214-215], (X) [97:263-264], (XI) [98:332]

LIPSKI Jan Aleksander kardynał (I) [82:204-205], (IV) [85:336], (VI) [89:359], (X) [97:264-265] • WP [86:308] • DO [90:134] • IP [93:181]

LIPSKI Konstantyn Samuel arcybiskup (II) [83:327], (VI) [89:360], (X) [97:265266]

LiPSKI Mateusz Melecjusz biskup (III) [84:259], (X) [97:266] (XI) [98:333] • IP [93:181-182]

LIPSKI Wincenty biskup (III) [84:259-260]

LISSOWSKI Herakliusz, arcybiskup (X) [97:326-327] - WP [86:308] • DO [90:134]

LITWINOWICZ Spirydon metropolita (X) [97:327] • IP [93:182]

LoKa Filip Michał Józef opat (XI) [98:377-378]

Lubart Piotr biskup (I) [82:205]

LUBomirski Hieronim Augustyn administrator opactwa (IV) [85:336-337] • WG [81:207-208]

LUBOMIRSKI Józef Stanisław administrator opactwa (IX) [95:269-270]

LUBORADZKI Antoni biskup (VIII) [94:215], (X) [97:267]

LuBstowsKi Ludwik Jakub Benedykt opat (XI) [98:378-379]

LuLia (Ludia) Marian biskup (V) [87:138]

Luszin (LuSCHIN) Franciszek Ksawery arcybiskup (X) [97:267] • IP [93:182183]

LASzcz Józef Antoni biskup (IV) [85:337], (IX) [95:270], (XI) [98:333] • WP [86:308-309] • DO [90:134]

LAsZewski Michal Remigiusz biskup (VII) [91:306], (IX) [95:270-271], (X) [97:268] • IP [93:183]

LĄCKI Franciszek biskup (X) [97:268-269]

LEMPICKI (LĘPICKI) Jakub administrator opactwa (IV) [85:337-338]

LĘTOWSKI Ludwik Stanisław biskup (II) [83:303], (X) [97:269] • IP [93:183]

LoDZIŃsKI Józef Antoni biskup (I) [82:197], (III) [84:281-282]

LOPACIŃSKI Jan Dominik biskup (IX) [95:271], (X) [97:269-270] • WP [86:309]

- DO [90:135]

LopaCIŃSKI Józef Leon biskup (IX) [95:271-272], (X) [97:270] • WP [86:309] • DO [90:135] • IP [93:183]

Loś Aleksander Ludwik opat (XI) [98:379]

LowCZowsKi (WŁoszczewsKi) Jan opat (VI) [89:379] 
LozA Stanisław biskup (XI) [98:333-334]

LUbIENIECKI (LubIENIECKI) Mikołaj Jan Damascen biskup (I) [82:206], XII [99:183] • IP [93:183]

LUBIEŃSKI Kazimierz biskup (I) [82:206-207, 221], (IV) [85:338], (X) [97:270271], (XI) [98:334] • IP [93:183-184]

LUBIEŃSKI Maciej administrator opactwa, arcybiskup (IV) [85:338-339], (VI) [89:380], (XI) [98:334-335]

LUBIEŃSKI Stanisław biskup (I) [82:207], (IV) [85:339]

LUBIEŃSKI Stefan Wojciech biskup (II) [83:303], (X) [97:271] • DO [90:135]

LuBIEŃSKI Tadeusz Feliks biskup (II) [83:304], (III) [84:282] • IP [93:184]

LUBIÉ́sKI Władysław Aleksander arcybiskup (IV) [85:340] • WP [86:309] • DO [90:135]

LUGOWSKI Szymon prepozyt generalny (VI) [89:380]

LUKOмSKI Józef opat (XI) [98:379-380] • IP [93:184]

Lukomsкi Mikołaj Antoni opat (XI) [98:380-381] • WP [86:310]

MachCZYŃski (MAChCiŃSKI) Teodor biskup-nominat (II) [83:304-305], (III) [84:273-274], (V) [87:138-139], (VIII) [94:216]

Maciejowska (MacieJewska) Agnieszka ksieni (VI) [89:381]

MACIEJowski Bernard kardynał (XI) [98:335]

MACIEjowski Samuel biskup (VI) [89:360]

MackIEWICZ Franciszek biskup (III) [84:260], (VI) [89:352] • IP [93:184]

MADALIŃsKI Bonawentura biskup (VI) [89:381], (VIII) [94:216-217], (X) [97:271-272], (XI) [98:335-336]

MAdaliński Stefan Teodor opat (XII) [99:155-157]

MaJerCZaK Maciej biskup (III) [84:260]

MaJewska Anna ksieni (V) [87:125]

MatachowsKi Jan biskup (I) [82:207-208, 222], (IV) [85:340-341], (VII) [91:320], (XI) [98:336] • IP [93:185]

MatoszyńsKa (MaŁaszý́sKa) Joanna ksieni (VI) [89:381-382]

Matowieski (Matowiecki) Adam Jan opat (XII) [99:xxx]

Manastyrski (Monastyrski) Antoni biskup (III) [84:261] • IP [93:186]

Manteuffel Erazm biskup (V) [87:139]

Manugiewicz Mikolaj Jan biskup (XI) [98:336-337] • IP [93:185]

MarCiejewski Polikarp Augustyn biskup (III) [84:261] • BT [93:129] • IP [93:185]

* Marcin Albaris z Kozierowa opat (V) [87:139-140]

MARKowsKI Edward opat-prepozyt (II) [83:323-324]

MARSZEWSKI Michal Jan biskup (X) [97:272] • IP [93:185]

De Marwitz Jan Nepomucen biskup (III) [84:262] • IP [93:185-186]

MAsSaLSKI Ignacy Jakub biskup (X) [97:272-273] • WP [86:310] • DO [90:135]

DE MATHy Ignacy Stanisław biskup (III) [84:262-263], (VII) [91:306-307], (X) [97:273] 
De Mathy Ludwik Józef biskup (I) [82:208], (IX) [95:272-273], (X) [97:274] • WP [86:310-311] • DO [90:135]

MAткоWSкI Innocenty opat (XI) [98:381]

MĄKOwSKI Adam administrator opactwa (VI) [89:382-383], (XII) [99:157-158]

MDzewsKi Michal Maurycy biskup (VIII) [94:217] • DO [90:135]

MozewsKi Stefan Antoni biskup (XI) [98:337]

Miaskowski Baltazar biskup (III) [84:289], (X) [97:274-275]

MiaskowsKi Józef biskup (III) [84:263] • IP [93:186]

Miaskowski Zygmunt biskup (X) [97:275]

Mieszkowski Piotr (starszy) biskup (X) [97:275-276]

Mieszkowski Piotr Pawel (młodszy) biskup (VIII) [94:218], (X) [97:276]

* Mikołaj z Kamiony opat (VI) [89:383]

* Mikolaj z Wieliczki opat (VI) [89:383-384]

Mikulowska (Mikolowska) Zofia ksieni (V) [87:125, 140]

Mirecki Krystyn Stefan opat (XII) [99:158-159]

MŁodzIEJOwsKi Andrzej Stanisław biskup (I) [82:208-209], (IV) [85:341], (IX)

[95:273], (XI) [98:337-338] • WP [86:311] • DO [90:136] • IP [93:186]

MtodzIEJowSKI Jan opat (VI) [89:384]

Mocki Jerzy tytularny opat (XII) [99:159]

MosZYŃSKI Konstantyn biskup (IX) [95:273-274, 295], (X) [97:276] • WP [86:311-312] • DO [90:136]

Możdżeniewski Maciej Pawel biskup (III) [84:263-264] • IP [93:187]

NARAMOWSKI Jerzy opat (XI) [98:381], (XII) [99:159-160]

NAruszewicz Adam Stanisław biskup (IX) [95:274-275], (X) [97:277], (XI) [98:338] • WP [86:312] • DO [90:136] • IP [93:187]

NARZYMSKI Antoni biskup (IX) [95:275], (X) [97:277-278] • WP [86:312] • IP [93:187]

NERSESOWICZ Deodat biskup (XI) [98:363], (XII) [99:184]

NIEborSKI Stanisław biskup (XI) [98:338-339]

Niegolewski Bernard opat (IV) [85:341-342]

NowiŃski Tomasz prepozyt generalny, biskup (I) [82:209], (II) [83:305], (III) [84:264], (V) [87:119-120], (X) [97:278] • IP [93:187]

Nowodworski Adam biskup (X) [97:279]

ОвовSкI Mikołaj biskup (I) [82:209-210], (IV) [85:342-343], (X) [97:279-280]

ОвоRSкI Tomasz biskup (I) [82:210], (VI) [89:360-361]

Odyniec (Brzozowiecki-Odyniec) Cyprian biskup (X) [97:280], (XII) [99:184]

OGIŃSKI Ludwik Karol biskup (XII) [99:184-185]

OKЕ̨CKI Antoni Onufry biskup (I) [82:210-211], (IV) [85:343-344], (IX) [95:276], (XI) [98:339] • WP [86:312] • DO [90:136]

OLechowsKi Józef biskup (I) [82:211], (X) [97:280-281] • WP [86:312] • DO [90:136] • IP [93:187]

OLeŚNICKa Anna ksieni (V) [87:126, 140] 
OlęDZki (OLendzki) Michał Ignacy Franciszek Józef biskup (IX) [95:276-277], (X) [97:281] • WP [86:313] • DO [90:137]

OLszowsKI Andrzej arcybiskup (XI) [98:339], (XII) [99:185]

Opalı́́sKI Kazimierz Jan biskup (VII) [91:307], (XI) [98:340]

Orański (Woyna-Orański) Adam biskup (VI) [89:351-352]

OssolińsKI Ignacy Franciszek Kandyd biskup (IX) [95:277], (X) [97:281], (XI)

[98:340-341] •WP [86:313] • DO [90:137] • IP [93:187]

Ostaszewski Beda opat (XII) [99:160-161]

OstaszewSKI Tomasz biskup (VIII) [94:239-240], (X) [97:282], (XII) [99:185] • IP [93:187-188]

OstrowsKi Antoni Kazimierz arcybiskup (III) [84:290], (IV) [85:344] • WP [86:313] • DO [90:137]

Ostrowski Daniel Eliasz biskup (X) [97:282] • IP [93:188]

Ożarowska Marianna ksieni (VI) [89:355-356]

PaC Kazimierz biskup (XI) [98:341-342]

Padniewsiki Filip biskup (I) [82:211]

Patucki Michal Wawrzyniec biskup (II) [83:305] • WP [86:313] • BT [93:128]

PaPRocki Waclaw biskup (III) [84:282], (X) [97:283]

Parczewsini Piotr biskup (X) [97:283]

* Pawel z Golczy opat (VI) [89:385]

Pawlowski Franciszek biskup (II) [83:306], (XI) [98:342] • IP [93:188]

Pawıowski Ignacy Ludwik arcybiskup (II) [83:306], (XI) [98:342-343] • IP [93:188-189]

Pawlowski Józef biskup (I) [82:212], (X) [97:284]

Petesz Julian biskup (IX) [95:296]

Piasecki Jakub Remigian administrator opactwa (VI) [89:385-386]

Piasecki Pawel administrator opactwa, biskup (VI) [89:386-387], (XI) [98:343]

Piechowski Michal Stanislaw biskup (II) [83:327-328], (VIII) [94:240-241],

(X) [97:284]

PieczNowski Marcin opat (VI) [89:387-388]

PieniążeK Aleksander opat (V) [87:126]

Pilchowicz Wojciech biskup (VII) [91:307-308]

PILchowski Dawid Zygmunt biskup (II) [83:307] • DO [90:137] • IP [93:189]

* Piotr ze Strzegomi opat (V) [87:152]

PIRAwski Tomasz biskup (VI) [89:361]

Pisztek Franciszek arcybiskup (X) [97:285] • IP [93:189]

Piwnicka Elżbieta ksieni (VII) [91:297-298]

Piwnicki Michal biskup (II) [83:307-308] • IP [93:189-190]

Pląskowski Fabian Franciszek biskup (X) [97:285] • WP [86:314] • DO [90:137]

PleJEwSKI Konstanty Wincenty biskup (II) [83:308, 328], (V) [87:141] • IP [93:190]

PoDHORODEŃsKi Jan Kanty Bożydar biskup (III) [84:264-265] • DO [90:137] 
Podoski Gabriel Jan arcybiskup (IV) [85:344-345], (VIII) [94:218], (IX) [95:278] • WP [86:314] • IP [93:190]

Polanowski Tomasz opat (VI) [89:388]

PoŁubiński Jerzy biskup (II) [83:308-309] • DO [90:137]

Poniatowski Maciej opat (IV) [85:345-346]

Poniatowski Michal Jerzy arcybiskup (I) [82:212-213], (IV) [85:346], (IX) [95:278-279], (X) [97:26-287], (XI) [98:343-344] • WP [86:314] • DO [90:138] • IP [93:190-191]

PonIśski Franciszek Ksawery opat (XI) [98:382] • WP [86:315]

Poniński Karol biskup (I) [82:213], (X) [97:287] • BT [93:128]

Poplawski Mikołaj arcybiskup (VIII) [94:219]

PotKański (PoDKański) Franciszek biskup (I) [82:213, 222], (IV) [85:346-347], (V) [87:152-153] • WP [86:315] • DO [90:138]

PotKański (PoDKański) Stanisław Hieronim administrator opactwa (IX) [95:297] • WP [86:315]

Ротоскі Teodor Andrzej arcybiskup (I) [82:223], (XI) [98:344] • WP [86:315] • IP [93:191]

Ротосzкі Jan Antoni biskup (VII) [91:295], (IX) [95:297] • IP [93:191]

Powlowski (Powslowski, Powstawski) Jerzy biskup (IX) [95:279] - WP $[86: 315] \bullet \mathbf{D O}[90: 138] \bullet \mathbf{I P}[93: 191]$

Powsiński Bartlomiej administrator opactwa (XII) [99:161-162]

PrażMowski Adam Michal biskup (X) [97:287-288] • IP [93:192]

PrażMowski Franciszek biskup (VIII) [94:219]

Prażmowski Mikołaj Jan arcybiskup (IV) [85:347-348], (VIII) [94:219-220]

Proszyński (Prószyński) Józef biskup (IX) [95:280] • WP [86:315] • IP [93:192]

Próchnicki Jan Andrzej arcybiskup (IV) [85:348]

Pruski Andrzej biskup (I) [82:198], (II) [83:329], (X) [97:288-289] • WP [86:315] • IP [93:192]

Pruszkowski (Prószkowski) Józef Franciszek Michal opat (V) [87:126-127]

Przebendowski Jan Joachim Henryk biskup (IV) [85:348]

Przebendowski Teodozjusz opat (IV) [85:349]

Przerębski (Przerembski) Adam administrator opactwa (IV) [85:349], (IX) [95:280, 297-298]

PrzYŁuski Leon Michal arcybiskup (II) [83:309] • IP [93:192]

Pstrokoński Maciej biskup (III) [84:283]

Pstrokoński Stanisław biskup (VI) [89:389]

Puzyna Nikodem biskup (III) [84:265] • IP [93:192]

RaCzYŃSKi Bartłomiej Antoni (Wawrzyniec) opat, biskup (III) [84:265], (X) [97:289], (XI) [98:382-383]

RACZYŃSKI Ignacy arcybiskup (II) [83:309-310], (X) [97:289-290] • DO [90:138] - IP [93:192-193]

RADLIŃSKI Jakub Pawel prepozyt generalny (XI) [98:383-384]

RadoszewsKa (RAdoszowsKa) Elżbieta ksieni (XII) [99:162] 
RAdoszewski (RAdoszowski) Bogusław biskup (XI) [98:344-345]

Radoszewski (RAdoszowski) Wojciech Józef biskup (VI) [89:361-362], (VIII) [94:241-242], (X) [97:290-291], (XII) [99:185-186] • DO [90:138]

RADZIEJowski Michał Stefan kardynał (X) [97:291-292] • IP [93:193]

RADziwitŁ Jerzy kardynał (I) [82:214], (II) [83:329], (VI) [89:362-363]

Radziwılıówna Krystyna Eufemia ksieni (XII) [99:162]

RAPACKA Helena Antonina ksieni (III) [84:290]

REgowski Szczęsny (Feliks) opat (V) [87:153]

ReszKa Stanisław administrator opactwa (VI) [89:389-390], (XII) [99:162-164]

Rogowski Iwo Onufry biskup (VII) [91:308] • WP [86:316] • DO [90:138] • IP [93:193]

RoKITNICKI Kazimierz biskup (V) [87:141], (VIII) [94:220], (IX) [95:281] • WP [86:316] • DO [90:139] • BT [93:128]

RostKowski Adam Franciszek biskup (II) [83:310, 319-320], (V) [87:141-142], (VIII) [94:220-221] • WP [86:316]

RostKowski Piotr administrator opactwa (XII) [99:164-165]

RośCISZEWSKI Zygmunt biskup-nominat (IV) [85:350]

Roz(D)RAżewSKI Hieronim biskup (III) [84:283-284]

Roz(D)RAżewSKI Jan Antoni administrator opactwa (XII) [99:165] - WP [86:317]

Roz(D)Rażewski Pawel Marcin opat (XII) [99:165]

RUDNICKI Sylwester biskup (XII) [99:186]

RudNiCKI Szymon biskup (VII) [91:308-309]

RUDZIŃSKI Stefan Atanazy biskup (X) [97:292]

RupNiEwski Stefan Bogusław biskup (IV) [85:350-351], (X) [97:292-293] • WG [81:220]・ WP [86:317] • IP [93:193]

RyBiński Józef Ignacy Tadeusz biskup (IV) [85:351], (IX) [95:281-282] • WP [86:317] • DO [90:139]

RYDZYŃSKI Franciszek Ksawery biskup (VII) [91:309-310], (X) [97:293] • WP [86:317] • DO [90:139] • IP [93:193]

RYєŁo Maksymilian biskup (XI) [98:384] • WP [86:317-318] • DO [90:139] • IP [93:193]

Rzezawski Franciszek Edmund opat (IV) [85:351]

SANGuszko Hieronim Wladysław biskup (XI) [98:345-346]

SAPIEHA Aleksander biskup (XI) [98:346-347]

SAPIEHA Franciszek Antoni opat (XI) [98:384-385]

SAPIEHA Józef Julian biskup (IX) [95:282], (X) [97:293-294], (XII) [99:186] • WP [86:318]

SaPIEHA Pawel Franciszek Bernard opat, biskup (II) [83:324], (XI) [98:347]

SARNOWSKI Stanisław biskup (IV) [85:352], (XI) [98:347-348]

SEmbratowicz Józef metropolita (X) [97:327-328] • BT [93:126, 127] • IP [93:194]

SIECIŃSKI Stanisław biskup (IV) [85:352-353]

Siemianowska Marianna ksieni (V) [87:127, 142] 
SIEMIEŃSKI Marcin biskup (I) [82:214-215], (II) [83:311], (III) [84:266], (X) [97:294]

SieniawSKa Zofia ksieni (V) [87:127-128, 142-143]

SienIeński (SIENIÍski) Dominik biskup (IV) [85:353], (VIII) [94:242] • DO [90:116]

SIERAKowSKI Antoni Maciej biskup (IX) [95:283] • WP [86:318]

SiERAKowski Michal Roman biskup (II) [83:320], (IX) [95:283-284], (X) [97:295] • WP [86:318] • DO [90:139]

SiERAKowSKI Waclaw Hieronim arcybiskup (IV) [85:353-354], (VIII) [94:242 -243], (X) [97:295-296], (XI) [98:348] •WP [86:318] • DO [90:139]

SIERAKOwSKI Waclaw (młodszy) nominat na sufraganię (IV) [85:354]

SIESTRZEŃCEWICZ Stanisław Jan arcybiskup (IX) [95:284] • WP [86:318-319] • DO [90:140]

SKARBEK Jan arcybiskup (VIII) [94:243] • WP [86:319] • IP [93:194]

Skarszewska Justyna Magdalena ksieni (V) [87:128, 143]

SKaRSZEWSKI Wojciech Józef arcybiskup (II) [83:311], (VI) [89:352-353], (XI) [98:348-349] • WP [86:319] • DO [90:140] • IP [93:194-195]

SKIRMUNT Joachim biskup (XII) [99:187]

SKoroszewSKI Jerzy opat (XII) [99:166]

SкотnICKa Elżbieta Magdalena ksieni (V) [87:128-129, 143]

SкотNICKI Krzysztof opat (IV) [85:354-355], (V) [87:120], (XI) [98:385]

SкотNICKI Tomasz biskup (I) [82:215], (X) [97:296]

SKOWIERSKa (SKOWIESKa) Elżbieta ksieni (VI) [89:390-391]

Skuminowicz Teodor biskup (X) [97:296]

SŁaWIANowsKa Kazimiera ksieni (XII) [99:166]

SŁUPSKI Mikolaj biskup (XI) [98:348]

SMOGoRzowSKI Jazon arcybiskup (XI) [98:364] • WP [86:319] • DO [90:140]

Sовоска Weronika ksieni (II) [83:324]

SокоцоWSкI Aleksander biskup (X) [97:297]

SoкоŁowski Piotr biskup (X) [97:297]

SoŁтyк Kajetan Ignacy biskup (III) [84:290-291], (IV) [85:355], (VI) [89:363]

-WP [86:319] • DO [90:140]

SоŁтYк Maciej Aleksander biskup (VII) [91:310-311] • IP [93:195]

Sosnkowski Józef Frydygian opat (V) [87:129-130], (XII) [99:167] • WP [86:320]

SosNowski Leon Konstanty biskup (IX) [95:284-285], (XII) [99:187] • WP [86:320] • DO [90:140] • BT [93:129]

SPENDOwSKa Salomea przełożona (XI) [98:386]

StANIEwSKI Józef Maksymilian biskup (III) [84:266-267] • IP [93:195-196]

Starczewski Stanislaw biskup (VIII) [94:221], (X) [97:298], (XII) [99:188]

STASZEwSKa Barbara ksieni (V) [87:130]

STASzewski Chryzostom Feliks opat (V) [87:153]

Stefanowicz Franciszek biskup (III) [84:267] • IP [93:196]

STEFANOWICZ Samuel Cyryl arcybiskup (IX) [95:298]

STEMPKOwsKi (STĘPKOWSKI) Ludwik opat, biskup (V) [87:144] 
STEMPKowSKi (STĘPKowski) Stanisław prepozyt generalny (XI) [98:386-387] von STRaChwitz Jan Maurycy biskup (X) [97:298-299] • WP [86:320] • IP [93:196]

STRadomsKa Anna ksieni (VI) [89:391]

STRASZYŃski Pawel biskup (II) [83:312]

StroJnowski Hieronim biskup (III) [84:267], (IX) [95:298-299], (X) [97:299], (XI) [98:349-350] • DO [90:141]

STUPNICKI Jan biskup (X) [97:328-329]

SulIŃski Zygmunt administrator opactwa (XII) [99:167]

SuŁowsKI Stanisław administrator opactwa (VI) [89:391-392]

SzaJowsKi Kasper biskup (VIII) [94:244], (IX) [95:285] • WP [86:320] • DO [90:141]

Szaniawska Ludwika Scholastyka ksieni (XII) [99:167-168]

SzaniawsKi Konstantyn Felicjan biskup (I) [82:215-216, 223], (III) [84:291], (X) [97:299] • WP [86:320]

Szczuka (SczuKa) Kazimierz Jan biskup (VII) [91:311, 321], (X) [97:300]

Szedziński Stanisław biskup (X) [97:300]

SzembeK Franciszek Antoni biskup (I) [82:198], (IV) [85:355-356], (VIII) [94:244]

SzembeK Józef Eustachy Piotr biskup (III) [84:284], (IV) [85:356], (IX) [95:286], (XI) [98:350] • WP [86:321] • DO [90:141]

SzeMbeK Krzysztof Antoni arcybiskup (XI) [98:351] • WP [86:321] • DO [90:141] • IP [93:196-197]

SzembeK Krzysztof Hilary biskup (I) [82:216], (IV) [85:356-357], (IX) [95:286287] • WP [86:321] • DO [90:141] • IP [93:197]

SzeMвEK Krzysztof Jan Andrzej biskup (IV) [85:357], (V) [87:144-145], (VII) [91:312], (X) [97:300-301], (XI) [98:351] • WP [86:321]

SzEMBEK Ludwik administrator opactwa (IV) [85:358]

Szembeк Michał biskup (IV) [85:358], (X) [97:302] • WG [81:219]

Szeмвек Onufry Kajetan biskup (II) [83:312-313], (IV) [85:358-359], (VIII) [94:221-222] • DO [90:141] • IP [93:197]

SzembeK Stanisław arcybiskup (II) [83:330], (IV) [85:359-360], (VII) [91:312313], (X) [97:302], (XI) [98:352] • WG [81:214-215] • IP [93:197]

SZEPTYCKI Atanazy biskup (IX) [95:299-300] • WP [86:322]

SzePTyCKI Hieronim Antoni biskup (I) [82:217], (VIII) [94:245], (XI) [98:352 -353] - WP [86:322] • DO [90:142]

SZEPTYCKI Leon Ludwik arcybiskup (IX) [95:300] • WP [86:322] • DO [90:142]

SzoŁdRSKI Andrzej biskup (IV) [85:360], (X) [97:302-304], (XI) [98:353]

SzUMBorski Filip Felicjan biskup (X) [97:329]

SzYDŁowski Stanisław opat (VI) [89:392]

SZYJKowSKI Jan biskup (IX) [95:287] • WP [86:323]

SzYsZKowski Marcin biskup (XI) [98:353-354]

Szyszkowski Mikołaj biskup (IV) [85:361, 393], (VII) [91:313], (VIII) [94:222223] 
ŚCIERSKI [ŚCIRSKI] Jan opat (XII) [99:168]

ŚNIGóRSKI (SNIGURSKI) Jan biskup (X) [97:329-330]

ŚwIĘCICKI Mikołaj Stanisław biskup (XI) [98:354, 387], (XII) [99:188]

ŚwIĘCICKI Stanisław Jacek biskup (XII) [99:188]

ŚwIRSKI Mikołaj biskup (VIII) [94:245]

ŚwitanowsKa (SwitanowsKa) Bronisława ksieni (VI) [89:364]

TARŁo Jan Joachim biskup (I) [82:217], (IV) [85:361-362], (X) [97:304] • WP [86:323]

TARŁO Michal Bartlomiej biskup (I) [82:217-218] • IP [93:197]

TARŁo Piotr biskup (I) [82:218], (IV) [85:362-363] • IP [93:197-198]

TARŁówna Anna ksieni (II) [83:325]

TaRŁówna Franciszka ksieni (V) [87:130, 145]

[TARnawiecka Agnieszka] ksieni (II) [83:325]

TARnowska Barbara ksieni (V) [87:131, 145-146]

TARNOWSKI Jan arcybiskup (II) [83:330], (IV) [85:363], (XII) [99:168]

TERASZKIEWICZ Jan biskup (X) [97:330-331]

ToczyŁowski (SAmson-ToczyŁowski) Piotr Aleksander biskup (X) [97:305] • WP [86:323] • DO [90:142] • IP [93:198]

ToLIBOwski Ludwik biskup (VIII) [94:223]

Tolibowski Wojciech biskup (VIII) [94:223-224], (X) [97:305], (XI) [98:354355]

ToMaszewski Walenty Maciej biskup (II) [83:313], (III) [84:284]

TREMbeCKA Joanna przeorysza (V) [87:154]

Trzcińska Anna Cecylia ksieni (VI) [89:393-394]

Trzciński Józef Michał biskup (IX) [95:287-288] • WP [86:323]

Trzebicki Andrzej biskup (I) [82:218], (IV) [85:363-364], (VIII) [94:224-225]

Trzebiński (TrzebieŃski) Aleksander administrator opactwa, biskup (IV) [85:364], (V) [87:154], (VI) [89:394], (XI) [98:355], (XII) [99:168-169]

TrZeBiński Benedykt administrator opactwa (I) [82:219], (IV) [85:365]

Trzecieska Barbara ksieni (V) [87:131-132, 146]

Trzemeski Kasper biskup (X) [97:306]

TUMANOWICZ Jakub Walerian arcybiskup (X) [97:331] • DO [90:142]

TursKi Bonawentura nominat na sufraganię (IV) [85:365]

Turski Feliks Pawel biskup (I) [82:219], (IX) [95:288], (XI) [98:355] • WP [86:324] • DO [90:142]

TURSKI Szymon prepozyt generalny (IV) [85:366]

TyszkIEwICZ Antoni Dominik biskup (X) [97:306], (XI) [98:356], (XII) [99:189]

-WP [86:324] • DO [90:142-143]

TyszkiEwICz Jerzy biskup (IV) [85:366-367], (VIII) [94:246], (XI) [98:356357]

UCHAŃSKI Jakub arcybiskup (X) [97:306-307]

UJEJSKI Tomasz biskup (VIII) [94:225]

URBAŃSKI Antoni Onufry biskup (IX) [95:288-289] 
WACŁAWICZEK (VÁCLAvíčeK) Wacław arcybiskup-nominat (III) [84:268]

WaLewski Przemyslaw Antoni opat (XI) [98:387-388]

WALKNowski Wladyslaw Jan Antoni biskup (I) [82:220], (IX) [95:289] • WP [86:324] • DO [90:143]

WAZA Karol Ferdynand biskup (I) [82:224], (VI) [89:364]

Wąsowiczówna Krystyna ksieni (V) [87:132]

WĄTRÓbKa (STRZELECKI) Jan arcybiskup (X) [97:307]

WERESZCZYŃsKi Józef opat, biskup (VI) [89:356]

Wessel Adam Augustyn biskup (I) [82:199], (V) [87:146], (VIII) [94:225], (X) [97:307-308] • WP [86:324] • DO [90:143]

WĘŻYK Jan arcybiskup (IV) [85:367]

WężYK Walenty Franciszek biskup (II) [83:331], (IV) [85:368], (VIII) [94:225 -226] •WP [86:324-325] • DO [90:143]

WĘŻYK Wojciech administrator opactwa (IV) [85:368-369]

WielewiejSKI (WIELOWIEJSKI) Lukasz Krzysztof biskup (II) [83:313], (X) [97:308] • DO [90:116]

WielHorsKa Anna ksieni (VII) [91:298]

WIELICKI Maciej biskup (XII) [99:189]

WIELogŁowsKi Hieronim biskup (IV) [85:369], (X) [97:308] • WP [86:325] • DO [90:143]

Wierzbowski Hieronim biskup (X) [97:308-309]

Wierzbowski Stefan (starszy) biskup (VI) [89:353]

Wierzbowski Stefan (młodszy) biskup (VIII) [94:226]

WierzChLEJSKI Franciszek Ksawery arcybiskup (III) [84:268], (IX) [95:300301], (X) [97:309] • IP [93:199]

WieszCZYCKI Antoni Olegar opat (XII) [99:169]

WILCZYŃski Andrzej biskup (IV) [85:369-370]

WiLKSYCKI (WILXYCKI) Baltazar biskup (I) [82:199, 220], (X) [97:309-310]

WiLKSYCKI (WILXYCKI) Jan biskup (III) [84:269], (VII) [91:314], (X) [97:310] • IP [93:199]

WINNICKI Innocenty opat (XI) [98:388-389]

WitosŁawski Michal Piotr biskup (IX) [95:289], (X) [97:310] • WP [86:325]

WitTan Rafal opat (V) [87:132-133]

WoDzICKI Jan Kanty administrator opactwa (IV) [85:370]

WoDZICKI Michal biskup (IV) [85:370] • WP [86:325] • DO [90:143]

WoJakowski Maurycy Maciej biskup (II) [83:314] • BT [93:129] • IP [93:200]

WoJeŃSKI Stanisław biskup (IV) [85:371], (XI) [98:357]

WoJtarowicz Józef Grzegorz biskup (II) [83:314], (X) [97:311] • IP [93:200]

WoJTKIEwICZ Adam biskup (III) [84:269-270] • IP [93:200]

Wolicki Cyprian Kazimierz biskup (III) [84:285], (VIII) [94:226], (IX) [95:290] • WP [86:325-326] • DO [90:144] • IP [93:200]

WoLICKI Teofil arcybiskup (II) [83:315], (X) [97:311] • IP [93:201] ${ }^{92}$

Wolczacki (Woltczacki) Walenty biskup (X) [97:311-312] • WP [86:326]

${ }^{92}$ Mylnie jako Wolski Teofil. 
WoŁŁowICz Andrzej biskup (III) [84:270, 285], (VIII) [94:227] • WP [86:326]

- DO [90:144] • IP [93:201]

WоєоркоWICZ Felicjan Filip arcybiskup (XI) [98:364] • WP [86:326] • DO [90:144]

WolonczewSKI (WolŁonczewski) Maciej biskup (III) [84:270-271] • IP [93:201]

WoŁowski Jan Antoni opat (XII) [99:169-170]

WoŁucki Pawel biskup (III) [84:285-286, 291]

Woronicz Jan Pawel arcybiskup (XI) [98:357] • IP [93:201-202]

Woyna (WoJNa) Abraham biskup (XI) [98:357-358]

WYdżGa Jan Stefan arcybiskup (IV) [85:371-372], (XI) [98:358]

Wyganowski Antoni Felicjan Alberyk opat (XI) [98:389]

Wyноwsкi (Wychowski) Aleksander biskup (VIII) [94:227-228]

Wysocki Franciszek Ignacy biskup (I) [82:199-200]

WYSOCKI Jozafat opat (XI) [98:390]

WyżYCKI (GERALD-WyŻYCKI) Mikołaj (starszy) administrator opactwa, biskup (XII) [99:170]

WyŻYCKI (GERALD-WyżYCKI) Mikołaj Ignacy (młodszy) arcybiskup (IV) [85:372], (IX) [95:290], (X) [97:313], (XI) [98:359] • WP [86:327] • DO [90:144]

ZaborowsKi Krzysztof opat (VI) [89:395]

ZachariasiewicZ (ZaChariasZewICZ) Franciszek Ksawery biskup (II) [83:315], (VII) [91:295-296], (X) [97:312-313] • IP [93:202]

ZaChaRIaSIEWICZ (ZaChaRIaSZEWICZ) Grzegorz biskup (X) [97:313-314] • IP [93:202]

ZADZIK Jakub biskup (IV) [85:373], (VI) [89:364-365], (VIII) [94:228], (IX) [95:301], (XI) [98:359-360]

ZAJERSKI Franciszek biskup (VIII) [94:228], (X) [97:314]

ZaLIŃSKI Wawrzyniec opat (V) [87:147]

ZAŁĘSKI Antoni Leon Tomasz biskup-nominat (IX) [95:291-292]

Zatuski Andrzej Chryzostom biskup (II) [83:316], (IV) [85:373-374], (V) [87:147], (VII) [91:314-315], (VIII) [94:228-229]

ZAŁUSKI Andrzej Stanisław biskup (III) [84:286], (IV) [85:374], (VIII) [94:229], (X) [97:314-315] •WP [86:327] • DO [90:144] • IP [93:203]

ZAŁUSKI Hieronim administrator opactwa (IX) [95:301-302]

ZAŁuSKI Józef Andrzej biskup (III) [84:292], (IV) [85:374-375], (VIII) [94:229230] $\bullet$ WP [86:327] • DO [90:144]

ZaŁUSKI Ludwik Bartlomiej biskup (VIII) [94:230-231]

ZaŁUSKI Marcin (starszy) biskup (II) [83:317], (V) [87:147-148], (VII) [91:315], (VIII) [94:230-231, 246-247], (X) [97:315-316], (XII) [99:189-190]

ZAŁUSKI Marcin (młodszy) biskup (IV) [85:375-376], (VIII) [94:231], (X) [97:316] • WP [86:328] • DO [90:116, 117]

ZaŁUSKI Pawel Antoni biskup (VIII) [94:231-232], (X) [97:316-317] 
ZAMBRZYCKI Franciszek Remigiusz biskup (II) [83:317] • DO [90:145] • IP [93:203]

ZAMoyski Jan Chrzciciel biskup (XI) [98:360]

ZaMoYski Jerzy biskup (VIII) [94:232], (X) [97:317], (XII) [99:190]

ZAPOLSKI Jan Zygmunt administrator opactwa (IV) [85:376], (XI) [98:390 $-391]$

ZARUSKI Bernard opat (XII) [99:171]

ZвĄSкI Jan Stanisław biskup (VII) [91:315-316], (X) [97:317-318], (XI) [98:360] - IP [93:203]

ZвоRowska Zofia ksieni (V) [87:133, 148]

ZDANOWSKa Wiktoria ksieni (VI) [89:365]

ZebrZyDowski Andrzej biskup (VI) [89:365-366]

ZeBRZYDOWSKI Józef Bernard opat (IV) [85:376-377]

DE Zehmen Karol Ferdynand biskup (VII) [91:316], (IX) [95:291], (X) [97:318]

- DO [90:145]

ZGLENICKI Franciszek Ksawery biskup (II) [83:318] • IP [93:203-204]

ZIEGLeR Grzegorz Tomasz biskup (III) [84:271], (X) [97:319-320] • IP [93:204]

ZIELIŃSKI Konstanty Józef arcybiskup (VIII) [94:232-233], (XI) [98:360-361]

ZIENKowICZ Michał (Mikołaj) Jan biskup (X) [97:319], (XII) [99:190-191] • WP [86:328] • DO [90:145] • IP [93:204]

Zienkowicz Tomasz Ignacy biskup (X) [97:319-320], (XI) [98:361], (XII) [99:191-192] • WP [86:328] • DO [90:145] • BT [93:129]

ZıóŁKowıCZ (ZıóŁKIEWICZ) Kazimierz opat (XII) [99:171-172]

ZwIEROwICZ Stefan Aleksander biskup (III) [84:271-272] • IP [93:204]

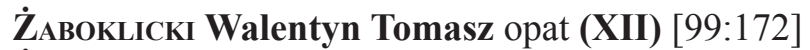

ŻARNOWIECKI Stanisław biskup (I) [82:220-221], (X) [97:320-321] • IP [93:204]

ŻEGOCKI Krzysztof Jan biskup (VI) [89:366-367], (X) [97:321]

ŻEGOCKI Mikołaj opat (VI) [89:353-354], (XII) [99:172]

Żochowski Cyprian metropolita (XII) [99:192]

ŻóŁKowsKi Antoni Józef biskup (X) [97:321-322], (XII) [99:192-193] • WP [86:328] • DO [90:145] • BT [93:128]

Żórawski (Żorawski, Żurawski) Michal biskup (V) [87:148-149], (VIII) [94:233], (IX) [95:292] • WP [86:329] • DO [90:145]

Źórawski Władysław opat (XI) [98:391]

ŻYLIŃSKI Waclaw Kazimierz arcybiskup (III) [84:272-273], (X) [97:322] (XI) [98:361-362] • IP [93:204]

słowa kluczowe: biskup, opat, Rzeczpospolita Obojga Narodów, biografia, zabory 


\title{
SOURCE EXTRACTS FOR THE BIOGRAPHIES OF POLISH BISHOPS AND ABBOTS FROM THE TIME OF THE POLISH-LITHUANIAN COMMONWEALTH AND THE PARTITIONS OF POLAND $\left(16^{\mathrm{TH}}-19^{\mathrm{TH}}\right.$ CENTURIES). (PART XII)
}

\begin{abstract}
Summary
The twelfth part, closing the series Source extracts, comprises three sections. The first two, entitled Monastica and Varia, bring another portion of information, taken from the archives and manuscripts, for the biographies of the representatives of the Old Polish hierarchy of the Catholic Church - bishops, abbots and abbesses. The third one is a cumulative index of the included persons, which comprises all the previous parts of Source extracts. It enables researchers to easily explore the rich and diverse material published in 2004-2013, and referring to a total of 683 characters. The index also includes the related editions on this topic, published by the same publisher in the pages of the semi-annual "Archiwa, Biblioteki i Muzea Kościelne" - it mentions, however, only those persons who appear in the individual parts of Source extracts.

A wealth of factual data, introduced into the scientific world thanks to this series, should greatly assist in further prosopographical studies on the Old Polish church elites, particularly in the often postulated development of biographical dictionaries of both bishops and abbots from the time of the Polish-Lithuanian Commonwealth.
\end{abstract}

Keywords: bishop, abbot, Polish-Lithuanian Commonwealth, biography, partitions 